EDNÉA APARECIDA DA SILVA BOSO

\title{
MULHERES EM TRANSGRESSÃO: A VISIBILIDADE DA VOZ FEMININA EM VOZES DO DESERTO DE NÉLIDA PIÑON
}


EDNÉA APARECIDA DA SILVA BOSO

\section{MULHERES EM TRANSGRESSÃO: A VISIBILIDADE DA VOZ FEMININA EM VOZES DO DESERTO DE NÉLIDA PIÑON}

Dissertação apresentada à Faculdade de
Ciências e Letras de Assis - UNESP -
Universidade Estadual Paulista para obtenção
do título de Mestre em Letras (Área de
Conhecimento: Literatura e Vida Social)

Orientadora: Dra. Cleide Antonia Rapucci

ASSIS

2011 
Dados Internacionais de Catalogação na Publicação (CIP) Biblioteca da F.C.L. - Assis - UNESP

Boso, Ednéa Aparecida da Silva

B744m Mulheres em transgressão: a visibilidade da voz feminina em Vozes do deserto de Nélida Pinõn / Ednéa Aparecida da Silva. Assis, 2011

$192 \mathrm{f}$.

Dissertação de Mestrado - Faculdade de Ciências e Letras de Assis - Universidade Estadual Paulista.

Orientador: Dr ${ }^{\mathrm{a}}$ Cleide Antonia Rapucci

1. Pinõn, Nélida, 1938 - 2. Literatura brasileira. 3. Crítica feminista. 4. Mulheres na literatura. I. Título. 


\section{EDNEA APARECIDA DA SILVA BOSO}

MULHERES EM TRANSGRESSÃO: a visibilidade da voz feminina em "Vozes do deserto" de Nélida Piñon

Dissertação apresentada à Faculdade de Ciências e Letras - UNESP para a obtenção do título de Mestre em Letras (Área de Conhecimento: Literatura e Vida Social)

Data da Aprovação: 20/06/2011

\section{COMISSÃO EXAMINADORA}

Aslopuer.

Presidente: PROFA. DRA. CLEIDE ANTONIA RAPUCCI - UNESP/AsSis

\section{thath}

Membros: PROF. DR. ALTAMIR BOTOSO - UNIMAR/Marília

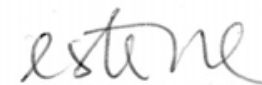

PROF. DR. ANTONIO ROBERTO ESTEVES - UNESP/ASSIS 
Aos meus pais João e Odete, amigos e heróis, minha admiração.

À minha filha, Steffani, como testemunho de todo o meu amor e carinho. 


\section{AGRADECIMENTOS}

Em princípio, a Deus por ter dado força, coragem e perseverança para enfrentar essa trajetória que fora delineada desde a graduação.

Posteriormente, à Nossa Senhora Aparecida que possibilitou vislumbrar tantas pessoas "anjos" que colaboraram de alguma forma, com pequenos gestos, ações, palavras, conselhos, sugestões ou, até mesmo, dicas para que esta pesquisa obtivesse êxito.

Então, convém destacá-las para que juntos possamos comemorar a conquista de mais uma etapa de minha vida, pois esta é a página que nem as marcas deixadas pelo tempo conseguirão dissipar do livro que ficará gravado minha história.

À minha orientadora, Prof ${ }^{-}$Dra . Cleide A. Rapucci, por ter dado a oportunidade de poder desenvolver esta pesquisa com presteza e eficácia. Na verdade, ela foi uma mãe quando me acolheu e guiou, com sabedoria, meus passos nos preciosos momentos de conhecimento. Minha eterna gratidão!

À Prof ${ }^{a}$ Dr$^{a}$ Lúcia Zolin da Universidade Estadual de Maringá (UEM) pelos emails respondidos e, em especial, pela apresentação do romance Vozes do Deserto.

À Prof ${ }^{a}$ Dr $^{a}$ Peggy Sharpe da Florida State University (FL/Talahassee), pelo acolhimento em sua residência, enfim, por tudo que ela fez para que eu pudesse dar prosseguimento a esta pesquisa. Obrigado pela confiança e apoio MOM!

Aos meus pais, João e Odete, a quem poderia ter dado maior atenção como filha e, talvez, ajudado mais no trabalho cotidiano. Infelizmente, isso não foi possível, mas quero que saibam que seu apoio e os constantes incentivos me fizeram acreditar que estava no caminho certo. Amo vocês!

À minha filha, Steffani, luz dos meus olhos, peço desculpas pela ausência em todos os momentos que ela imaginava estar "sozinha". Sem dúvida, eu estava lá, embora longe dos olhos, mas perto do coração.

Aos meus irmãos, Edson e Edna, que compreenderam a minha luta para alcançar mais este objetivo em minha vida.

Ao meu esposo, Sidnei Boso, que, com muita paciência, soube tolerar as minhas "teimosias e chatices", percorrendo as rodovias de "ida e volta" à UNESP, bem como 
aos constantes congressos a que me levava à busca incessante do saber. Obrigado por ter compartilhado os momentos mais difíceis!

Aos meus primos, Antonio Pedro Longo e Arlete, que não mediram esforços para cuidar da minha filha nos momentos em que mais precisava!

Aos meus sobrinhos, Eduardo, Bruno, João Junior, Juliana, João Victor e Gabrielly, por compreenderem porque não acompanhei mais de perto o crescimento de vocês.

A todos os meus professores da Graduação, em especial, Silvia Maria Azevedo, Sandra Ap ${ }^{\mathrm{a}}$ Ferreira, Luiz Roberto Veloso Cairo e Antonio R. Esteves, que foram fonte de luz e inspiração para eu descobrir a fascinação do mundo literário.

Aos meus inesquecíveis amigos, Norma Choukaira, Meirielle Escobar, Cristina Gobetti, Carmen Rosita, Odete Guirro, Doroti, Fernando, Renata, Thiago Valente, Maurício Aquino, Leandro Rechenchosky, Suzana Coco, Nice Major, Célia Azevedo, Letícia Gonçalves, Marcio Cantarin, entre outros que, por hora, me faltam à memória.

À Maria José Generich Marques, Clarice da Silva Coneglian e Eleida Zanutto, muito mais que Diretoras, amigas que sempre estiveram "abertas" para me ouvir nos momentos de desespero, dando total apoio e compreensão.

À Dirigente Regional de Ensino de Ourinhos, Silvia Maria Rodrigues Nunes Cantarin, por ter-me guiado à UEM (Maringá) e aconselhado a "correr atrás dos meus sonhos" na Pós-Graduação.

Às minhas amigas separadas pela distânca, Sadalena, Victória Marsee, Kátia Espassandim, Cinira e Márcia (H.A.C), que deixaram saudades e mostraram que tudo é possível quando acreditamos com fé naquilo que fazemos.

À seção de Pós-Graduação e Biblioteca pela prontidão e pelos esclarecimentos prestados nos momentos de dúvidas na realização desta pesquisa e durante toda a minha permanência na UNESP.

Portanto, as palavras se tornam cada vez mais escassas para expressar toda a minha gratidão a estes "anjos" que não simplesmente passaram por minha vida, mas deixaram marcas indeléveis na minha alma. Por isso, acredito, fielmente, que, sem a cooperação e colaboração dessas pessoas, este trabalho seria inconcebível no presente momento. Muito Obrigada e que DEUS os abençõe sempre! 
Deus!

Que as minhas palavras sejam precisas

Para que eu

possa ser Vista,

Ouvida e Compreendida

Assim,

Sinto que houve

Um contato entre nós 
BOSO, E.A.S. Mulheres em transgressão: a visibilidade da voz feminina em Vozes do deserto de Nélida Piñon. Dissertação (Mestre em Letras - Literatura e Vida Social) Universidade Estadual Paulista - UNESP, 2011.

\section{RESUMO}

O objetivo deste trabalho é demarcar o espaço da escritora Nélida Piñon na literatura de autoria feminina, refletindo sobre as vias de acesso que se abriram quando ela retomou uma das personagens mais conhecidas e míticas da história da Literatura Universal, Scherezade, no romance Vozes do deserto (2004). Este estudo permitiu que se realizasse uma reflexão mais acurada sobre a construção desta personagem a partir da perspectiva da critica feminista (SHOWALTER, 1994) e que se revelasse a condição feminina em um sistema hegemônico, coercivo e patriarcal que legitima as situações de poder, submissão, opressão e violência em relação às mulheres. Sendo assim, este trabalho é um convite para que se conheça a contribuição de Nélida Piñon à luz da evolução contemporânea e da emancipação consciente das mulheres que ousaram transgredir os limites do tempo e espaço em prol de sua visibilidade, independência, liberdade e reconhecimento como sujeito da história. Esses aspectos permitem contemplar as três fases: feminina, feminista e mulher, da literatura de autoria feminina estabelecidas por Elaine Showalter. Apesar de esta obra de Nélida Piñon ser ainda pouco estudada pela crítica brasileira, ela é importante também para os estudos da ginocrítica devido ao discurso crítico especializado sobre os textos produzidos por mulheres. Esta dissertação pretende valorizar o ser mulher que protagoniza não somente a história, mas a ascensão do seu próprio destino no mundo. Em conclusão, a 
escritora é nome de relevo para o universo literário brasileiro, sendo uma profunda conhecedora da história das mulheres e, portanto, atenta e comprometida com o atual cenário sócio-político cultural brasileiro.

Palavras- Chave: Nélida Piñon, literatura feminina, crítica feminista, mulher, personagem feminina, Vozes do deserto. 
BOSO, E.A.S. Women in transgression: the visibility of female voice in Voices of the desert by Nélida Piñon. Dissertation (Master's in Languages - Literature and Social Life) - São Paulo State University - UNESP, 2011.

\section{ABSTRACT}

The genesis of this work is to demarcate the area of the writer Nélida Piñon in the female authorship literature reflecting about the access roads that were opened when the author retook one of the most well-known and mythical character of the Universal Literature - Scherezade - in the novel Voices of the Desert (2004). So, this study allowed to realize a more accurate reflection about this character's construction from the perspective of feminist criticism (SHOWALTER, 1994) bringing out the feminine condition in a hegemonic system, coercity and patriarchal that legitimizes the power situations, submission, oppression and violence against women. Therefore, this work is an invitation to know Nélida Piñon's contribution in contemporary evolution and women's emancipation awareness who dared to transgress the boundaries of time and space to promote their visibility, independence, freedom and recognition as a subject of the history. These aspects allow to gaze on the three phases: feminine, feminist and female of the Women's literature established by Elaine Showalter. Although this novel has been little researched by Brazilian criticism yet, it is also important to the gynocritical studies because the gynocriticism speech is a critical and specialized speech about texts written by women. So, this dissertation intends to enhance (value) the female who stars not only the history but makes possible the rise of her own destiny in the world. To conclude, the writer is outstanding name for the Brazilian Literary Universe and she demonstrates 
a deep knowledge about women's history and, therefore, attentive and compromised with the current social political and cultural Brazilian scenery.

Key words: Nélida Piñon, women's literature, feminist criticism, woman, female character, Voices of the desert. 


\section{SUMÁRIO}

INTRODUÇÃO

1.1 - Cronologia: vida e obra 22

1.2 - Nélida, a escritora intelectual no século XXI 28

1.3 - A arte da criação literária: uma estética da experiência humana . 36

1.4 - Para além das fronteiras brasileiras: repercussões e críticas 41

1.5 - O estado da questão: a (re) significação de Vozes do deserto 45

CAPÍTULO 2 - A perpetuação de um mito: da Scherezade oriental até a Scherezade brasileira 50

2.1 - De volta ao túnel do tempo: revendo o passado da arte milenar de contar histórias 51

2.2 - O eterno retorno: As mil e uma noites 61

2.3 - As recriações de Scherezade 68

2.4 - Scherezade em Vozes do deserto 71

CAPÍTULO 3 - Os entrelaçamentos de poder, erotismo e feminismo em Vozes do deserto 83

3.1 - Olhares sobre a crítica feminista: uma (re)visão 84

3.2 - Do feminismo ao pós-modernismo: uma articulação .... 87

3.3 - Sob o jugo do poder, erotismo e feminismo . 95

3.4 - Visões projetivas da cultura contemporânea: a representação de Scherezade no arquétipo da Grande Mãe e Penélope 116 
CAPÍTULO 4 - 0 mundo das mulheres

4.1 - O poder das palavras: as vozes do romance 123

4.2 - Mulheres transgressoras: em busca da visibilidade 133

4.3 - O molde: de mulher para mulher, a repetição na diferença pela liberdade....

4.4 - Feminino transgressor em Nélida Piñon 139 145

ANEXO 1 - Lista de obras críticas sobre o trabalho de Nélida Piñon 


\section{INTRODUÇÃO}

As mais altas composições líricas são, por isso, aquelas nas quais o sujeito, sem qualquer resíduo da mera matéria, soa na linguagem, até que a própria linguagem ganha voz. 
Há alguns anos, acompanhamos com grande interesse os estudos e pesquisas sobre o universo literário feminino e o que nos instigou foi o modo como este universo emergiu de uma forma avassaladora entre o século XVIII e o século XXI.

Percebemos um campo fértil que se abriu quando tentamos trazer à tona obras de mulheres que se lançaram no mundo da escrita meio que na "surdina", mas "em pé de igualdade" para serem reconhecidas e se tornarem parte integrante da literatura brasileira e, consequentemente, do cânone literário nacional.

Ao adentrar neste afloramento de novos rumos e perspectivas em narrativas de autoria feminina, este trabalho passou por um processo laborioso, almejando transcender os limites do tempo e do espaço em prol da visibilidade das inúmeras vozes que ressoaram e reivindicaram, dia após dia, noite após noite (do Oriente ao Ocidente), uma oportunidade de difundir a palavra e obter valores de justiça, igualdade e liberdade perante todo um sistema ideológico dominante e patriarcal.

Dentre as várias vozes, convém destacar a de Nelida Piñon que, de fato, contribuiu para dignificar, resgatar e legitimar a participação da mulher como sujeito na própria história e, assim, desconstruir, em tempos pós-modernos, a visão estereotipada de representação da mulher como mero objeto. Dessa forma, lançamos luzes sobre o romance Vozes do deserto, publicado em 2004.

O referido romance retoma, como um mito, uma das mais célebres histórias da Literatura Universal, As mil e uma noites, histórias estas narradas pela voz da jovem mais bela da corte, chamada Scherezade, que, para salvar as demais jovens do reino das garras do poderoso Califa, decide casar-se com ele. Todavia, ela não acredita que o poder deste ser "desprezível" possa determinar o fim de sua imaginação ou de sua liberdade.

Levando-se em conta o exposto e tendo em vista uma crescente tendência quanto à análise, reflexão e interpretação de obras literárias produzidas por mulheres, enfatizaremos uma leitura na contemporaneidade, de modo que se possa vislumbrar a construção da personagem "Scherezade" sob novos olhares e perspectivas na narrativa e, ao mesmo tempo, incitar, questionar e conscientizar a sociedade acerca dos problemas que envolvem a mulher. Na verdade, a intenção é "rasgar os véus" e desnudar essas complexas temáticas, revelando uma série de mitos, preconceitos e 
estereótipos que afligem não somente a mulher da sociedade considerada arcaica e patriarcal, mas todas as mulheres do mundo em geral.

O título Mulheres em transgressão, a visibilidade da voz feminina em Vozes do deserto de Nélida Piñon institui-se como uma porta de abertura para o mundo da visibilidade das inúmeras vozes que clamam contra o silêncio manifestado por toda uma geração de mulheres. Vozes que foram camufladas, injustiçadas e declaram-se insatisfeitas com esse espaço infértil para firmar-se e tornar-se Mulher. Vozes abandonadas e vedadas de demonstrarem os seus anseios literários ou não, os mais íntimos sentimentos, desejos e emoções, perante uma sociedade preconceituosa e machista, resultante de uma intensidade de experiências catastróficas que vão desde uma violência sexual (exploração do corpo), submissão, opressão e repressão após uma noite de coito mal-feita e sem amor, tesão e/ou até mesmo orgasmo até a clemência pela própria vida. Desta maneira, essa porta de abertura significa luz para as mulheres em transgressão, bem como o (re)direcionamento para novos rumos pavimentados de sonhos, fantasias e ideias revolucionárias, garantindo-se a perpetuação de identidade, humanização e universalidade da mulher.

Diante do exposto, esta dissertação está dividida em quatro capítulos: Situando Nélida na cultura brasileira contemporânea; A perpetuação de um mito: da Scherezade oriental até a Scherezade brasileira; Os entrelaçamentos de poder, erotismo e feminismo em Vozes do deserto e, finalmente, O mundo das mulheres. Convém enfatizar que o Anexo, em que consta a lista de obras críticas sobre o trabalho de Nélida Piñon, é parte de uma investigação realizada na biblioteca Robert Manning Strozier Library in the Florida State University e, junto com as fontes de pesquisas existentes na literatura brasileira, servirá como guia de referência para os futuros pesquisadores da área de literatura de autoria feminina brasileira.

O primeiro capítulo está configurado em cinco partes. A primeira parte apresenta cronologicamente vida e obra da escritora Nélida Piñon na cultura brasileira contemporânea.

A segunda parte refere-se à representação da escritora como intelectual no século XXI e culmina, posteriormente, na arte da criação literária como estética da experiência humana. Assim, na quarta parte serão visualizadas, para além das 
fronteiras brasileiras, as repercussões e críticas que envolvem a vida desta autora no âmbito nacional e internacional. Já a quinta parte enfatiza o estado da questão em que se encontra o romance Vozes do deserto, expondo a sua significação no universo literário brasileiro.

O segundo capítulo possibilita viajar de volta ao túnel do tempo para rever o passado da arte milenar de contar histórias. Desta maneira, viabiliza um estudo sobre o eterno retorno de uma das narrativas que mais instigou o imaginário humano, intitulada As mil e uma noites. Na verdade, este estudo concentra-se nas partes subsequentes, tornando visível as recriações de Scherezade na história, bem como sua representação na Ficção em Vozes do deserto.

O terceiro capítulo volta os olhares sobre a crítica feminista, propondo uma revisão a fim de que se possa estruturar o movimento de mulheres que conseguiram libertar-se das amarras patriarcais. Nesse sentido, a segunda parte empreende uma articulação do Feminismo ao Pós-Modernismo na concepção de algumas escritoras como Hollanda, Hutcheon, Showalter, Zolin entre outras. Então, sob o jugo do poder, erotismo e feminismo, norteia-se uma análise pautada nas personagens femininas, em especial Scherezade, apresentando-se, sucintamente, algumas passagens para a comprovação dos aspectos mencionados, que expressam com maior nitidez o estilo da escritora Nélida Piñon no percurso de toda uma trajetória dedicada à literariedade nacional e internacional. A partir daí, serão projetadas visões do mito de Scherezade na cultura contemporânea por intermédio dos arquétipos da Grande Mãe e Penélope.

Este estudo culmina no quarto capítulo, que revela o mundo das mulheres a ser descortinado por intermédio do poder das palavras que engendram uma polifonia de vozes narrativas. Cabe lembrar que essas vozes contribuem para particularizar e, ao mesmo tempo, pluralizar o universo de mulheres em via de transgressão. Nesse romance, Nélida Piñon expõe múltiplas perspectivas sobre as questões do feminismo emergente, que se faz ouvir não somente na literatura brasileira, mas em todo o mundo, uma vez que busca dar maior visibilidade às mulheres no tempo e no espaço. Desta maneira, o molde de mulher para mulher reforça a idéia de repetição de uma imagem feminina que se envereda para outra sob o olhar da diferença, pela liberdade que fora ocultada/negligenciada durante anos da história. Na verdade, são mulheres que entram 
em cena e expõem, sem medo, os mais íntimos sentimentos e emoções para desconstruir os tabus e mitos construídos sobre elas, configurando assim, o feminino transgressor de Nélida Piñon.

Em particular, Vozes do deserto constrói seu tema central sobre a mulher e, consequentemente, sobre suas experiências cotidianas, seus sentimentos, emoções, sensações e desejos que refletem um contínuo processo de transformação do ser humano. Assim, "nós", enquanto meros aprendizes e leitores, somos capazes de ler nas entrelinhas aquilo que está imerso num emaranhado de fios narrativos, testemunhando a intimidade da mulher, os segredos privados e universais e, ao mesmo tempo, de contemplar a arte da criação, invenção, o mistério do eterno sagrado, do profano e da fé, na captação do momento ápice sinérgico validando essa história com a audácia da memória/imaginação e, assim, erigimos e consagramos um novo templo visível para as mulheres em plena transgressão.

Em Vozes do deserto, Nélida Piñon, com exímio domínio da arte da palavra, tece os fios narrativos para compor sua célebre criação literária. Então, a escritora se apodera da história original apenas como pretexto para narrar aquela que esteve camuflada durante anos: a situação da mulher no mundo contemporâneo. Assim, a intenção é elucidar e propulsionar, por meio da audaz heroína chamada Scherezade, a fertilidade da imaginação feminina, bem como a importância do papel da fantasia na vida do ser humano.

Desta maneira, a autora não tenciona mostrar uma preocupação com as histórias que a personagem Scherezade conta ao Califa, mas sim, com o (re)direcionamento da visibilidade da mulher nas diversas áreas de conhecimento, ao assumir a posição de escritora, narradora, personagem, contadora de histórias, leitora, esposa, mãe, filha, amante, conselheira, mestra e, acima de tudo, mulher.

A história é cíclica e inesgotável, pois ninguém tem o poder de decretar o esgotamento da imaginação e, consequentemente, da mente humana. Por isso, o desfecho final permanece em aberto para admitir uma nova trança de histórias, sustentada pela amarração dos fios narrativos que culminam na revelação da enigmática história de mulheres. Com certeza, tais mulheres superaram inúmeros obstáculos para firmar-se como sujeitos, na medida em que ousaram vislumbrar novos 
rumos e perspectivas para garantirem sua visibilidade, independência, liberdade e reconhecimento ao longo da história.

Sendo assim, espera-se que este estudo seja uma fonte de apoio, inspiração e inquietação para os futuros leitores e pesquisadores que almejam também transgredir e transcender a realidade na qual estão inseridos e mergulhar nesta fascinante história de imaginação e fantasia guiada pelas mãos da escritora Nélida Piñon, sobre Scherezade, que ressalta a luta contra as diversas formas de poder estabelecidos sobre a mulher durante toda uma tradição. 


\section{CAPÍTULO 1 \\ SITUANDO NÉLIDA PIÑON NA CULTURA BRASILEIRA \\ CONTEMPORÂNEA}

Os escritos de uma mulher são sempre femininos; não podem deixar de sê-lo; quanto melhor, mais feminino; a única dificuldade é definir o que entendemos por feminino. 


\subsection{CRONOLOGIA: VIDA E OBRA ${ }^{1}$}

Nélida Cuiñas Piñon nasceu no dia 3 de maio de 1937, em Vila Isabel, na cidade do Rio de Janeiro, filha de Olívia Carmen Cuiñas Piñon e Lino Piñon Muiños.

No ano de 1910, seu avô materno, Daniel Cuiñas, tinha chegado de Carballedo (Cotobade) com a intenção de "conquistar o Brasil".

Aos dez anos, muda-se com os pais e os avós maternos para Borela, na Galiza, onde permanecem por dois anos. É interessante notar que a aldeia galega, assim como a forte presença da natureza tornaram-se uma descoberta e um encantamento, fonte de inspiração, para a menina e, posteriormente, iriam consagrar-se na sua ficção.

Após esse período (1956), Nélida vive uma temporada de quatro meses com a mãe e uma tia. Na chegada ao Brasil, seu pai, as recebe com uma festa no cais do porto.

Em 1957, gradua-se em Jornalismo pela PUC do Rio de Janeiro. Durante a faculdade escreve para o jornal universitário Unidade. Em 1959, publica os primeiros contos.

Em 1961, publica o romance Guia-mapa de Gabriel Arcanjo. A crítica a considera inovadora em sua linguagem, porém hermética, conforme se evidencia em uma entrevista que a escritora concedeu à Folha de S. Paulo, em 1978.

[...] Em 61, quando estreei, ganhei estigma de ser uma escritora difícil, uma escritora de elite, quando, naquele momento, eu estava iniciando minha campanha pessoal, minha campanha de artista em relação a uma linguagem. Eu buscava expressar-me através de uma linguagem nova, de uma sintaxe pessoal.

Lutei por isso porque, desde menina, compreendia que tinha de subverter a sintaxe bem comportada, pois as palavras que nela estão, são, de modo

\footnotetext{
${ }^{1}$ As informações sobre a vida e obra da escritora Nélida Piñon foram extraídas de sites da Internet dentre os quais citamos: http://virtualbooks.terra.com/osmelhoresautores/biografias/NelidaPinon.htm; www.nelidapinon.com.br; www.nelidapinon.com.br/panorama/inte/panentrevistas100anosABL.php; http://digestivocultural.com/colunistas/ http://revistalingua.uol.com.br/textos.asp; www.wagnerlemos.com.br/nelidapinon.htm>;http://brunogarschagen.com/ 2007;www.circuloleitores.pt/cl/artigofree.asp?.
} 
geral, também muito comportadas. São palavras oficializadas, institucionalizadas, estatutizadas. Então, eu busquei um caminho que subvertesse essa noção de realidade que me implantavam. Pressenti que a realidade que me deixavam ver era insuficiente, que havia outros níveis de realidade. E que me cabia ir atrás deles, ainda que expondo-me, com riscos à minha reputação de artista.

Após dois anos, publica o romance Madeira feita cruz. Escreve contos e artigos para a imprensa brasileira e torna-se correspondente da revista Mundo Novo, editada em Paris.

No ano de 1965, recebe a bolsa de estudos Leader Grant, concedida pelo governo americano. Assim, viaja pelos EUA, onde realiza conferências sobre literatura brasileira, visita universidades e faz amizades no meio intelectual norte-americano. Desde então, a escritora realiza inúmeras viagens de caráter pessoal e profissional.

A partir de 1966, exerce o cargo de editora-assistente da revista Cadernos Brasileiros (Rio de Janeiro), colaborando também em diversos jornais. Publica Tempo das frutas, livro de contos. Em 1969, publica um outro romance intitulado Fundador.

Em 1970, assume a direção do recém-criado Laboratório de Criação Literária na Faculdade de Letras da UFRJ. Recebe o Prêmio Walmap pelo romance Fundador. Depois de um ano, amplia sua produção textual principalmente no terreno da crônica e realiza também várias palestras. Faz-se necessário salientar que, em suas crônicas, aparecem os grandes movimentos de contestação feminista e estudantil contra a guerra do Vietnã que a escritora presenciava. Em 1972, publica o romance $A$ casa de paixão.

No ano seguinte, publica o livro de contos Sala de armas. Posteriormente, recebe o prêmio Mário de Andrade (da APCA - Associação Paulista de Críticos de Arte) por A casa de paixão.

Em 1974, publica o romance Tebas do meu coração. Após três anos, publica o romance $A$ força do destino. Cabe lembrar, ainda, que Nélida participa da redação do primeiro documento da sociedade civil contra a ditadura, entregue ao Ministro da Justiça.

Em 1978, é eleita vice-presidente do Sindicato dos Escritores do Rio de Janeiro, com Antonio Houaiss na presidência. Foi escritora visitante da Universidade de 
Columbia, por um semestre. Participa de simpósios e encontros de escritores na Dinamarca, Suécia, Espanha e Estados Unidos. Além disso, viaja pelo Brasil, proferindo palestras. É nomeada diretora da Divisão Cultural - Secretaria Estadual de Cultura do Rio de Janeiro.

Após dois anos, publica o livro de contos $O$ calor das coisas. Participa do Congresso do Pen Club Internacional, nos EUA. Realiza diversas palestras em Nova York e em diversas cidades brasileiras. Já em 1981, passa quarenta e cinco dias em Congonhas, escrevendo o romance $A$ república dos sonhos, na pensão Cova de Daniel.

Em 1983, Araken Távora realiza um vídeo biográfico sobre Nélida, para o projeto Encontro Marcado. O projeto propõe encontros de escritores com estudantes universitários, com palestra, debate e apresentação do documentário. Em 1984, publica A república dos sonhos. Além disso, participa do projeto Encontro Marcado em diversas universidades. Colabora na concepção do Programa de Política Cultural de Tancredo Neves (candidato à Presidência da República). Faz diversas palestras na Espanha.

Em 1985, participa da elaboração de um Programa Cultural para o Ministério da Cultura, juntamente com outros oitenta intelectuais. É eleita membro do Pen Club do Brasil. Integra a comitiva de dez escritores brasileiros em visita oficial a Portugal. Nessa época, o romance $A$ república dos Sonhos ganha o Prêmio Ficção do Pen Club considerado como o melhor livro do ano, e o Prêmio APCA (Associação Paulista de Críticos de Arte). Participa do II Encuentro de Intelectuales por la soberania de los pueblos de Nuestra América, em Havana, Cuba.

No ano seguinte, participa de congresso de escritores em Moscou, o primeiro depois da abertura (glasnost). Grava entrevista para o arquivo Library of Congress (Departamento Hispânico), em Washington. Percorre os EUA e Espanha realizando diversas palestras. Participa como jurada do Prêmio Latino-Americano de Literatura de Manágua, na Nicarágua.

Em 1987, publica o romance $A$ doce canção de Caetana, que recebe o Prêmio José Geraldo Vieira, da União Brasileira de Escritores de São Paulo, por ser considerado o melhor romance do ano. Em março, viaja para a França, com um grupo de escritores brasileiros, em visita oficial. Segue, em junho, para Valencia, onde toma parte no Congreso Internacional de Intelectuales y Artistas, em comemoração dos 50 
anos do Primeiro Congresso Anti-Fascista, organizado durante a Guerra Civil Espanhola. Durante esse ano participa de congressos de literatura no México, Peru, Alemanha, França e Canadá. Além disso, é nomeada presidente da Associação de Amigos da Casa de Cultura Laura Alvim, no Rio de Janeiro, cargo que exerceu por um ano.

Em 27 de julho de 1989, é eleita para a Academia Brasileira de Letras. Recebe o título de Personalidade do Ano, deferido pela União Brasileira de Escritores. Participa de Congresso de Escritores de Língua Portuguesa, em Lisboa, e, em abril, viaja aos EUA para o lançamento de The republic of dreams, traduzido por Helen Lane.

Em 1990, toma posse na ABL com o discurso "Sou Brasileira Recente". Recebe pelo conjunto de obras, o Prêmio Golfinho de Ouro-Letras, concedido pelo Governo do Estado do Rio de Janeiro. É condecorada com o grau de Oficial da Ordem de Rio Branco. Intensifica o ciclo de palestras internacionais e nacionais. Ademais, integra a Delegação Brasileira que definiu o Acordo Ortográfico da Língua Portuguesa, assinado por sete países lusófonos.

No ano seguinte, assume a Cátegra Henry King Stanford em Humanidades, na University of Miami, ministrando cursos semestrais de Literatura Comparada até 1993. Participa do XVI International LASA Congress (Latin American Studies Association), em Washington. Também atua como palestrante em encontro sobre o meio ambiente em Morélia, México. Integra o Grupo dos 100 Artistas e assina a Declaración de Morelia Manifiesto Ecológico de los 100 Artistas e Intelectuales. Recebe, pelo conjunto de obras, o Prêmio Bienal Nestlé na categoria romance.

Em 1992, a University of Miami organiza o International Symposium The World of Nélida Piñon, no Lowe Art Museum. Participa do Congresso Internacional do Pen Club e do Congresso Internacional de Literatura Iberoamericana, na Universidade de Barcelona. É condecorada com a Medalha Castelão, outorgada pela Junta de Galicia. Participa do Congresso Gabriel García Márquez, por ocasião dos 25 anos de publicação de Cem anos de solidão, em Zaragoza, Espanha. É condecorada com a distinção Lazo de Dama de Isabel la Católica, concedida pelo rei Juan Carlos da Espanha. É interessante notar que participou, com outros 40 intelectuais e artistas, do encontro sobre $A$ Cultura e os Meios de Comunicação, promovido pelo Cardeal Dom 
Eugênio Salles no Sumaré, Rio de Janeiro. Já em 1993, integra o Conselho Federal de Cultura, em Brasília. É designada como membro de honra da Phi Beta Delta Honor Society. Dirige o curso de Mujeres Creadoras, na Universidade Complutense.

Em 1994, publica o livro O pão de cada dia (fragmentos). Assina uma coluna semanal para o jornal carioca O Dia, que manterá até 1998. No ano seguinte, recebe o Premio de Literatura Latinoamericana y del Caribe Juan Rulfo, outorgado pela primeira vez a uma mulher e a um autor de língua portuguesa. É eleita primeira secretária da Academia Brasileira de Letras, sendo a primeira mulher, em 98 anos de existência da $\mathrm{ABL}$, a integrar a diretoria. Nomeada membro do Conselho Nacional dos Direitos da Mulher, integra a delegação brasileira junto à IV Conferência Mundial sobre a mulher, em Pequim, bem como a comitiva do Presidente Fernando Henrique Cardoso em sua visita ao México. Recebe o Prêmio Alejandro José Cabassa (União Brasileira de Escritores) pelo livro O pão de cada dia.

Em 1996, foi condecorada com a Medalha Águila Azteca, outorgada pelo Presidente do México. Publica o romance infanto-infantil $A$ roda do vento. Em 12 de dezembro, foi eleita Presidente da Academia Brasileira de Letras, primeira mulher a ocupar a Presidência da Casa de Machado de Assis. Em pleno exercício de sua função, organiza constantes eventos culturais que já fazem parte da programação da ABL e, consequentemente, dá início ao processo de informatização da $A B L$ com a criação e implantação do Centro de Memórias.

Em 1998, é nomeada Chevalier de L'Ordre des Lettres pelo governo francês. Recebe o título de Doutor Honoris Causa da Universidade de Santiago de Compostela, concedido pela primeira vez a uma mulher em 503 anos. Segue realizando conferências no México, França, EUA, Cabo Verde, Espanha e Brasil. Em 1999, é nomeada pelo Presidente Fernando Henrique Cardoso membro da Comissão de Honra dos Festejos do V Centenário do Descobrimento do Brasil. Publica o livro de crônicas Até amanhã, outra vez e o livro de contos O cortejo do divino. Em 2000, torna-se escritora residente na Universidade de Vanderbilt (Nashville, EUA). Ademais, faz a conferência de enceramento do Congresso Portugal-Brasil - Literatura e Língua, realizado por motivo dos 500 anos de descobrimento do Brasil. 
Em 2001, foi laureada com o Premio Iberoamericano de Narrativa Jorge Isaacs, pelo conjunto de obras. Foi o primeiro autor de língua portuguesa e a primeira mulher a receber este prêmio, em Cali (Colômbia). É convidada para a Cátedra Julio Cortázar, fundada e patrocinada por Gabriel García Márquez e Carlos Fuentes, da Universidade de Guadalajara (México).

Em 2002, publica o livro O presumível coração da América, uma seleção de discursos. Recebe o grau de Comendador da Ordem de Rio Branco, entregue pelo Presidente Fernando Henrique Cardoso, em Brasília. Durante uma semana, ocupa a Cátedra Alfonso Reyes, do Instituto Tecnológico de Monterrey (México). Já em 2003, é laureada com o XVII Premio Internacional Menéndez Pelayo.

Em 2004, é eleita para a Academia das Ciências de Lisboa. Lança o romance Vozes do deserto. Toma posse no Conselho Estadual de Cultura. Posteriormente, é designada pelo Presidente do Governo Espanhol, José Luis Zapatero, membro da Comissão do IV centenário da publicação do Quixote de Cervantes. É nomeada vicepresidente do Pen Club Iberoamericano.

Em 2005, é declarada filha adotiva de Cotobade, em cerimônia no salão nobre do Conselho de Cotobade. Nessa ocasião, fez a conferência "Galiza na minha obra". Além disso, nesse mesmo ano é indicada Puterbaugh Fellow pela Universidade de Oklahoma nos Estados Unidos. Em 2006, a Ibiza TV (Espanha) realiza o documentário Sherezade en Galicia, dirigido por Valentin Carrera, sobre sua vida e obra. As filmagens ocorrem no Rio de Janeiro. Por outro lado, há também as filmagens para o longametragem Nélida Piñon: o Atlântico e suas correntes, uma produção hispano-brasileira, dirigido por Júlio Lellis. O filme conta com depoimentos de amigos e escritores e cenas de ficção. Data também deste período a estréia da peça $A$ força do destino, adaptada de seu romance homônimo, no teatro do Centro Cultural Telemar (Rio de Janeiro). $O$ CEDIM (Conselho Estadual dos Direitos da Mulher) realiza o vídeo Nélida Piñon, dentro do projeto Memória Viva. Em seguida, a escritora toma posse na Academia de Filosofia do Brasil.

Em 2008, participa do lançamento do Livro Voices of desert, traduzido por Clifford Landers, em Nova York. Neste mesmo ano, lança o ensaio Aprendiz de 
Homero. Após esse período, publica, de forma inédita, o Ritual da arte. E, assim, ao dar continuidade à sua produção literária, lança o livro Coração andarilho, em 2009.

Convém ressaltar, ainda, que Nélida participou do chamado "Manifesto dos Mil Intelectuais", que foi o primeiro documento da sociedade civil contra a ditadura elaborado em grande parte por ela. Os integrantes deste grupo pequeno foram: Cícero Sandroni, Rubem Fonseca, José Louzeiro, Carlos Eduardo Novaes. Após o manifesto pronto, foram para Brasília Lygia Fagundes Telles, Hélio Silva, Jefferson de Andrade, representando Minas.

Diante de todo o exposto, podemos constatar que a vasta produção literária desta escritora demonstra a experiência proeminente da mulher intelectual que passou a integrar o novo filão cultural, um dos mais expressivos da cultura brasileira.

\subsection{NÉLIDA, A ESCRITORA INTELECTUAL NO SÉCULO XXI}

Mergulhamos num misterioso universo de sombras e luzes, um território arenoso e quase "movediço" em que os ventos oscilam os véus em que transparecem apenas contornos femininos. Ouvimos vozes, mas talvez seja uma projeção configurada pelo desejo de desvencilhar os valores androcêntricos apregoados por todo um sistema hegemônico, coercivo e patriarcal.

$\mathrm{Na}$ verdade, são figuras ilustres e enigmáticas que desfilam com desenvoltura em nossa imaginação e nos envolvem para que possamos reconhecê-las nesse espaço fértil de fantasias, de novas descobertas, autodescobertas, experiências, conquistas e de busca de identidade do próprio ser.

Então, ao segurar firmemente um dos tecidos transparentes, motivados por nossa curiosidade e ousadia e em gesto único, desvelamos esse enigma, erigindo entre contornos e vozes, a mulher que assume todas as formas humanas, Nélida Piñon, a escritora.

Desta maneira, escrever sobre um escritor que ocupa com grande vivacidade o universo literário é sempre uma tarefa árdua, porém, maior ainda é o desafio de falar 
sobre uma das escritoras mais talentosas do Brasil, que exerceu e exerce influência na produção intelectual de narrativas de autoria feminina, em especial, na Literatura Brasileira, tendo em vista a sua consagração estabelecida pela crítica nacional e internacional.

Diante desse posicionamento, convém ressaltar que a maioria das informações bibliográficas arroladas neste trabalho foram retiradas da página da própria escritora na Internet, de sites de jornais, de entrevistas, inclusive, uma delas concedida por Lucia Melo, secretária do Estúdio da escritora, via e-mail, em 12 de junho de 2008 (citada em Bonfim, na parte de artigos publicado na imprensa - Anexo 1), bem como por intermédio de pesquisas e pesquisadores da área de Literatura.

Nesta perspectiva, já dizia Clarice Lispector que "Escrever não é fácil, é duro como quebrar rochas, mas voam faíscas e lascas como aços espelhados" (LISPECTOR, 1975, p. 20), e é por meio desse processo árduo, penoso e solitário que se inscreve o poder da palavra, ou melhor, da linguagem durante toda a eternidade humana.

A escritora Nélida revela que a arte de escrever é "uma solidão coroada de espinhos e pouquíssimas flores..." (PIÑON, 2005, p. 2), mas para nós, enquanto mero aprendizes, aflorou como inspiração para podermo-nos engajar nesse movimento de mulheres "selvagens" que primam pelo olhar da diferença e da transgressão da realidade que nos circunda. Então, ao considerar os estudos realizados por Showalter (1994), podemos entender o vocábulo "selvagem" como uma área reservada somente às mulheres, às suas próprias experiências, um lugar do imaginário e do inconsciente que esteja fora do universo predominantemente dominado pelo poder masculino, ou seja, uma área proibida para os homens.

Escritora destemida e brilhante, romancista, novelista, contista, ensaísta, jornalista e professora, Nélida tem no Brasil a marca divisória de sua vida/obra denunciando a condição feminina ou, ainda, a discriminação social da mulher e, portanto, atenta e comprometida com o atual cenário sociopolítico cultural brasileiro.

Aos 73 anos e com mais de 45 anos de atividade literária, Piñon teve seus livros publicados em mais de 20 países e traduzidos para mais de dez idiomas. Desta maneira, as obras de Nélida configuram reflexões profundas e complexas acerca do ser 
humano e isto possibilita ao leitor "desfrutar" novas experiências, gerenciar conflitos, bem como descobrir o valor e a função da arte que é problematizar e conscientizar, de uma forma mais crítica, a defesa e a busca de uma vida melhor e mais digna.

Apesar de ser crítica e contestadora, revela nas entrelinhas e em tom intimista aqueles anseios do sujeito feminino resguardado, camuflado e, ao mesmo tempo, negligenciado pelo peso de uma ideologia dominante, arcaica e patriarcal.

A escritora demonstrou paixão pela arte de escrever desde criança, quando lia com volúpia os livros e imaginava aquilo que não estava ao seu alcance, pois para a Galiza foi levada menina, período em que aprendeu as lendas e a língua, assimilando sua poderosa oralidade, porque ali era o território onde as histórias, uma vez iniciadas, não têm fim.

Desta maneira, aspirava abarcar os seres e os enigmas, pois inventar seria postular liberdade e, com certeza, essa vocação foi herdada tanto do avô, Daniel, que se aventurou a desbravar novos horizontes, quanto de seu pai Lino, leitor assíduo, conforme pode-se evidenciar na seguinte passagem:

[...] Inventar é uma saga antiga, precedeu-me antes do nascimento. Talvez tivesse sido a vocação de meu avô, Daniel, imigrante galego, que se aventurou cedo a cruzar o Atlântico, obedecendo ao gosto da aventura, e à necessidade de instalar-se numa terra que lhe ofertasse horizontes mais amplos. Ou talvez inventar tenha começado com meu pai, Lino, igualmente disperso e com a cabeça tantas vezes mergulhada nos livros. (PIÑON, 2005, p. 2)

Vale lembrar, ainda, a influência de sua mãe, Olivia Carmen, que compartilhou muito mais que saberes, experiências que se consagrariam, posteriormente, nas suas obras, conforme menciona em uma entrevista concedida à Edla Van Steen (1982).

Nesta perspectiva, a engenhosidade e genialidade da escritura perante as relações humanas provêm dos seus antecessores, quer sejam familiares, amigos e/ou meios literários. Na verdade, empenhava-se em ir além do visível, em constante estado de vigília, para consolidar as experiências, artimanhas e seduções do próprio ofício, ao 
romper com as formas tradicionais já consagradas pelo cânone da história e da literatura.

Para Nélida, escrever é estar no epicentro das coisas, o centro onde está o sagrado, é transmitir conhecimento, palavras e todo um repertório para aqueles que supostamente irão suceder o escritor. Desta maneira, pode-se dizer que o escritor tem um papel moral a desempenhar na sociedade; é como se ele fosse uma criatura exemplar e comprometida totalmente com a vida, mas sujeita às "peripécias"/ "reviravoltas" que esta pode proporcionar ao longo de sua carreira.

Considerando ainda este posicionamento, Nélida tornar-se-á porta voz de um movimento que busca por voz, anseia por espaço na sociedade contemporânea, denunciando vários aspectos de sentimentos, dor, sofrimento, injustiça, insatisfação, violência sexual, submissão, repressão e até opressão de um determinado grupo, o feminino. Apesar de a escritora reunir e legitimar emoções e sentimentos não concretos, eles são amplos e inclusivos e somente através de uma narrativa como Vozes do deserto contemplar-se-ão as mais secretas histórias do sentimento humano que almeja a essência da vida e de liberdade.

Neste âmbito, ainda, pode-se dizer que Nélida Piñon é nome estelar na literatura brasileira, pois ela tem plena consciência da sua condição enquanto escritora, narradora, personagem, contadora, ensaísta, professora e, acima de tudo, mulher e sujeito da história, conforme afirma em uma entrevista concedida à Revista Língua Portuguesa:

Era inevitável chegar a esse romance. Eu vinha pensando na arte de fabular por anos e sabia que era a pessoa para isso. Porque tenho uma grande reflexão sobre a narrativa, já dei aula sobre criação literária, em meus cursos internacionais falo muito das técnicas e procedimentos narrativos, e vinha desejando fazer um livro que pensasse a imaginação e a fabulação como se fossem protagonistas. Mas como fazer isso sem correr o risco de fazer um ensaio? Cada vez mais eu amplio minha ação, não só como escritora. Faço ensaio, discursos, tenho uma reflexão, organização mental de ensaísta e um ímpeto de narradora. (PEREIRA JUNIOR, 2005, p. 1) 
Por outro lado, é interessante lembrar o ensaísta e crítico Otávio Paz (1972) quando argumenta que:

\begin{abstract}
Para nós o valor de uma obra reside em sua novidade: invenção de formas ou combinação das antigas de uma maneira insólita, descoberta de mundos desconhecidos. Revelações, surpresas: Dostoievski penetra no subsolo do espírito; Whitman nomeia realidades desdenhadas pela poesia tradicional, Mallarmé submete a linguagem a provas mais rigorosas que as de Gôngora e inventa o poema crítico; Joyce faz do idioma uma epopéia e de um acidente linguístico um herói (Tim Finnegan é a queda e a ressurreição do inglês e de todas as linguagens); Russel converte a charada em poema... Desde o Romantismo a obra há de ser única e inimitável. (PAZ, 1972, p. 81)
\end{abstract}

No fragmento acima, pode-se observar que todo o processo de criação de uma obra de arte traz no seu bojo profundas reflexões, descobertas e revelações por meio da linguagem consciente, única e inimitável em que o escritor transcende a própria realidade para criar o "novo", a sua obra-prima.

Segundo Vera Teixeira (1995), essa característica de escrita perfaz a narrativa de Nélida acerca do ser humano, pois ela sabe melhor do que ninguém

[...] fabricar imagens, cunhar palavras, construir estruturas inauditas, cultivar o idioma, além de contar estórias de sofrimentos, paixões, sonhos, pesadelos ou devaneios, [...] estudos miniaturizados da maravilhosa comédia humana. Ela não evade a luta. Ela aceita o desafio e escolhe as suas armas: palavras, palavras, palavras, palavras. (TEIXEIRA, 1995, p. 109-117)

A escritora tem um papel ativo na sociedade, tanto na área da consciência moral (ética) quanto estética, pois canaliza sua força imaginária (meditação, reflexão e criação) para trazer à tona as realidades e/ou verdades que não foram sempre visíveis para a sociedade e em nome daqueles que não podiam dizê-la, em uma luta constante 
contra as formas de poderes estabelecidos nessa sociedade capitalista (FOUCAULT, 2003, p. 71).

Convém salientar que a escritora age e interage com o seu tempo e espaço; que se pronuncia sistematicamente sobre a sociedade na qual está inserida. Além disso, tem o poder de retratar nas suas obras as experiências e situações cotidianas do universo feminino por meio de indagações importantes e necessárias para uma melhor reavaliação, atualização e compreensão não somente da obra em si, mas da valorização do escritor, do ser humano, do outro, do leitor e do mundo.

De acordo com Villarino Prado (2004), o assunto da situação da mulher, em especial, na literatura brasileira, aparece desde meados dos anos 60/70 e ganhou repercussão na voz de Nélida e, consequentemente, na voz das demais escritoras que também acompanharam esse "conflito" mais de perto, como Clarice Lispector, Lygia Fagundes Telles, entre outras, conforme se pode evidenciar na seguinte passagem:

[...] bastante natural que a literatura de autoria feminina dos anos 70 tematizasse insistentemente as consequências da sujeição da mulher ao poderio masculino da sociedade em que vivia. E essa narrativa da época exprime com vigor o conflito daquelas mulheres que adquirem consciência da escravidão mascarada de realeza nos domínios do lar e das barreiras encontradas no sentido de buscar uma saída para a própria liberdade. (VILLARINO PRADO, 2004, p. 283-298).

Este posicionamento complementa as ideias de escritor-intelectual expressas por Edward Said (2000) nas suas ponderações, que transcrevemos a seguir:

A esta tarefa extremamente importante de representar o sofrimento coletivo do próprio povo, de testemunhar o seu trabalho árduo, de reafirmar a sua perseverança, de reforçar a sua memória algo mais tem de ser acrescentado, algo que só um intelectual, creio eu, tem a obrigação de levar a cabo. Na verdade, muitos escritores, pintores e poetas, como Manzoni, Picasso ou Neruda, encarnaram a experiência histórica do seu povo em obras de arte, que se tornaram, por sua vez, reconhecidas como valiosas obras-primas. A tarefa do intelectual é, creio eu, universalizar, clara e inequivocadamente, a crise, dar uma maior abrangência humana ao que uma dada raça ou nação sofreu, associar essa experiência aos sofrimentos de outros. (SAID, 2000, p. 49) 
Neste âmbito, convém ainda lembrar Jean-Paul Sartre (1994, p.14-15), quando afirma que "[...] intelectual é alguém que se mete no que não é de sua conta e que pretende contestar o conjunto das verdades recebidas, e das condutas que nelas se inspiram, em nome de uma concepção global do homem e da sociedade [...]".

E é isso mesmo que a escritora Nélida Piñon faz no romance Vozes do deserto. Com acuidade "cutuca", subverte, joga, brinca e extrapola a linguagem, ao "trazer à tona" as verdades camufladas sobre as mulheres e algumas dicotomias como feminino $\mathrm{x}$ masculino, público $\mathrm{x}$ privado, presente $\mathrm{x}$ passado $\mathrm{x}$ futuro, prisão $\mathrm{x}$ liberdade, espaço aberto $x$ fechado, interior $x$ exterior, particular $x$ universal, efêmero $x$ eterno, antigo $\mathrm{x}$ moderno, vida $\mathrm{x}$ morte e memória $\mathrm{x}$ realidade. Vale enfatizar que esta última, memória e realidade, torna-se imprescindível, pois o escritor intelectual "moderno" deve munir-se de uma "caixa de ferramentas" necessárias para estimular essa presença da "memória" que se faz realidade e da realidade que se transfigura em memória (sonho/imaginação), ao transportar a realidade, por meio da escrita, no contexto real, encarando esta dita "realidade" tal qual ela é, de maneira verossímil para um determinado grupo social, sem contudo esgotar o assunto. No entanto, esta "verdade" e esta dita "realidade" parecem interpor-se, mas a própria autora ressalta que:

[...] a realidade na qual acreditamos é convencional... Eu sou contra a convenção, ela pode pôr em dúvida tudo. Com a imaginação não se aceita dogma, ela destrói a convenção. O poder tem pavor a imaginação... Cada vez que o poder agrilhoa o homem, a imaginação o liberta. (PIÑON, 2005, p. 3)

De acordo com o pensamento da autora proferido no Discurso de Recepção na Academia Brasileira de Filosofia (PIÑON, 2005), pode-se perceber que a imaginação do escritor funciona como uma arma contra os poderes estabelecidos. Complementando este pensamento, Michel Foucault (2003, p. 71) afirma que "[...] o papel do intelectual é o de lutar contra as formas de poder exatamente onde ele é, ao mesmo tempo, o objeto e o instrumento: na ordem do saber, da 'verdade', da 'consciência', do discurso". 
É valido observar que essa visão do intelectual se reflete nas palavras de Beatriz Sarlo, no sentido em que ela argumenta a redefinição do papel do intelectual ao enfrentar os novos arranjos da vida cultural contemporânea, conforme fragmento abaixo:

\begin{abstract}
A figura do intelectual (artista, filósofo, pensador), tal como criada na Modernidade clássica, entrou em seu ocaso. Algumas das funções que essa figura considerava suas, porém, continuam a ser reclamadas por uma realidade que mudou (e que portanto já não aceita legisladores nem profetas como guias), mas não tanto a ponto de tornar inútil o que foi o eixo da prática intelectual nos últimos dois séculos: a crítica daquilo que existe, o espírito livre e anti-conformista, o destemor perante os poderosos, o sentido de solidariedade com as vítimas. (SARLO, 1997, p. 165)
\end{abstract}

Para Pierre Bourdieu (1989, p. 56), o intelectual é uma personagem que só existe e subsiste como tal se (e apenas se) for revestido de uma autoridade específica, conferida por um mundo cultural autônomo, cujas leis específicas respeitam sem, porém, deixar de engajar-se em lutas sóciopolíticas. Por isso, precisamos de intelectuais que, sem abdicarem daquilo que os define como intelectuais, que é a perspectiva cultural da ação cívica, estejam imersos no mundo social, nele argumentem, nele articulem as suas às outras vozes sociais, vozes estas representadas aqui pelas Vozes do deserto, ao propor perguntas e respostas capazes de estimularem a nossa condição e prática de sujeitos significantes, reflexivos e pragmáticos, muito mais perceptíveis no mundo contemporâneo.

O perfil de "escritora-intelectual contemporânea" que se pretendeu esboçar migra para a complexidade do novo feminismo que será evidenciado nos capítulos posteriores e que emergiu quando as mulheres tentaram restabelecer-se e firmar-se como "diferentes", ousadas, independentes e críticas em busca de melhores dias vindouros e, especialmente, sem pudores em desafiar, enfrentar e questionar a sociedade e o mundo, ajudando a compor a sua história na humanidade.

Para concluir essa etapa, lembramos, ainda, o pensamento de Machado de Assis (1975, p. 18), quando diz que o que se deve exigir do escritor, antes de tudo, é 
certo sentimento íntimo, que o torne homem de seu tempo e do seu país, ainda quando trate de assuntos remotos no tempo e no espaço. Reflexão esta que, com certeza, garante a presença da voz de Nélida Piñon na cultura contemporânea por ela conceber para as mulheres um lugar de prestígio na sociedade, promovendo, assim, com mais rigor a visibilidade delas no século $\mathrm{XXI}$.

\subsection{A ARTE DA CRIAÇÃO LITERÁRIA: UMA ESTÉTICA DA EXPERIÊNCIA HUMANA}

Nélida Piñon contempla a literatura de autoria feminina brasileira com o romance Vozes do deserto, obra contemporânea ainda pouco estudada, que recupera uma das mais ricas tradições culturais, a oralidade, uma arte milenar que concentra conhecimento acumulado ao longo de anos de estudos, pesquisas, experiência e sabedoria que, com certeza, são passadas de geração em geração.

Neste âmbito, a escritora assegura que "explora o refinado patrimônio humano da imaginação através da arte de narrar. Dá importância ao caráter civilizador de qualquer narrativa de fabulação" (PIÑON, 2005). E, assim, demonstra toda a paixão pelo processo de criação e imaginação ao abarcar temas da vida humana.

A narrativa de Vozes do deserto nos remete à história antiga de As mil e uma noites, em que se expõe a saga de Scherezade e de inúmeras jovens que vivem no palácio do poderoso Sultão. Este, após a traição da sultana, decide condenar à morte todas as futuras pretendentes. Para pôr um fim a esta situação, a filha do Vizir decide casar-se com ele e se dispõe a interromper a série de assassinatos com sua astúcia na arte de narrar/contar histórias. Então, Scherezade, com a ajuda da irmã Dinazarda, das escravas e de Jasmine, surpreende o Califa, que atento às histórias mirabolantes, suspende a morte da princesa noite após noite.

Nélida apresenta aquela história do "texto-moldura" convertida numa espécie de "palimpsesto" - conceito este estabelecido por Gérard Genette (2006) - de maneira que se faz uma 'raspagem' do original apenas como "pretexto" para lançar uma outra 
"versão/história", que não a esconde de fato, de modo que se pode lê-la por transparência, o antigo sob um novo prisma: o da diferença. Assim, entendemos por palimpsestos, todas as obras derivadas de uma obra anterior, por transformação ou por imitação. $E$ isso possibilita constatar que a maior ênfase recai sobre a construção da personagem feminina que, incorporada na imagem de Scherezade, permite visualizar a mulher e, respectivamente, a sua interioridade numa espécie de "raio x" do ser humano.

A privacidade se torna pública, ou seja, é "escancarada" de tal modo que leva o leitor a vivenciar e participar ativamente da história. Portanto, aquelas histórias do "texto-moldura" de As mil e uma noites, contadas pela personagem Scherezade para ludibriar o Califa, já não interessam mais no contexto atual da obra e, consequentemente, ingressarão num plano inferior e sem êxito. A tendência, agora, é visualizar a mulher de todos os tempos na representação de Scherezade.

Mediante tal posicionamento, Nélida Piñon imbui no processo de criação a força da imaginação, ao retratar temas que envolvem a experiência de vida integrada ao papel da arte e da fantasia, em prol de uma vida mais digna, conforme observamos no seu discurso realizado em 2005:

\footnotetext{
É certo que vivemos distantes do epicentro cosmopolita, mas somos igualmente partícipes dos fados e das aventuras contemporâneas. Com igual severidade, registramos a apologia do mal em nome da salvaguarda da alma, a ascensão da barbárie, a palidez crescente dos princípios humanísticos tão ameaçados. Na ânsia, porém, de fertilizar o presente, e torná-lo mais solidário, expressamos inconformidade com uma ordem que, a pretexto de defender falsas premissas, imola inocentes, incensa a abundância para alguns em troca do sacrifício da maioria. Como se lhes havendo sido dado o privilégio de inaugurar uma sociedade ao seu feitio, desconsideram o estatuto da vida.

A matéria da arte, no entanto, resiste às crises que assolam as civilizações e recusa acordos prévios para existir. Afinal, feita de assombros, a arte origina-se do nosso humanismo. É perene, ainda que semeie angústias, discórdias. (PIÑON, 2005)
}

Para complementar o assunto, Nélida Piñon explica, em uma entrevista concedida a Wagner Lemos (2005), a escolha pela escritura de um livro de narração: 
[...] nos anos que se seguiram empenhei-me a fazer da própria narrativa personagem de um romance. Queria imergir em um universo que explicasse a vocação humana para resgatar valores de que dependemos para legitimar nossa história pessoal e, aquela outra, que nos circunda. Para isto, ao olhar o mapa, ancorei no Oriente Médio. Aquela região que quebrou o paradigma da invisibilidade e engendrou o monoteísmo. Um deus invisível e abstrato. Um novo conceito de fé. Portanto, avançando um pouco mais, enveredei pelo deserto, esta paisagem cruzada de caravanas, mentiras, histórias, intrigas, demônios, especiarias, seda. Estas rotas propícias a toda espécie de narrativa. Depois, coloquei a emblemática Scherezade no âmago mesmo de Bagdad, a cidade mítica e eterna. Com Scherezade e sua trupe à frente, circundados pela tirania do Califa, a imaginação se alvoroça e pretende triunfar. Daí, foi o fazer do romance ao longo de cinco anos, enquanto lia, estudava, adentrava-me pelo mundo islâmico. Um saber que, afinal, precisei dissolver em prol da integridade ficcional. (LEMOS, 2005)

De acordo com as palavras da escritora, percebe-se que é por meio de um prodigioso estudo e conhecimento que o autor transcende a própria realidade para aportar em uma outra dimensão, a da imaginação, já que esta pode exercer também o papel principal da trama e da capacidade humana, ao transgredir paradigmas e resgatar valores que são primordiais para legitimar a história de vida individual e/ou coletiva.

Em uma entrevista a Carmen Sigüenza (Folha On line, 2005), a escritora afirma que escolheu o Oriente Médio, precisamente Bagdá, por tratar-se "de um lugar no qual se reúnem três religiões monoteístas que abraçam um Deus invisível, e isso também é pura imaginação, porque é algo não tangível, não palpável; é tão sutil que seus efeitos provocam versões distintas".

A partir desse posicionamento, percebe-se que, para a escritora, a imaginação está arraigada na cultura árabe, porém, esta parece ainda estar submersa em uma cegueira branca que não permite visualizar a situação de opressão, submissão e discriminação vivenciada por grande parte das mulheres.

É neste ponto culminante que Nélida projeta a visão da mulher do Oriente para os dias atuais, de modo que o leitor possa sentir-se incomodado ou, até mesmo, indignado com essa questão e passe a refletir e interpretar a obra sob novos olhares, garantindo a ampliação de seus horizontes para além do mundo da escrita. 
$\mathrm{Na}$ verdade, é uma forma de romper com os padrões vigentes e convencionais, ressaltando-se o processo literário de interpretação e criação e, consequentemente, o envolvimento de forma cúmplice da tríade autor, obra e leitor, configurada pela estética da recepção.

Tive a sorte de ler tudo que queria. Jamais sofri censura. Portanto, tive acesso a toda classe de escritores que foram, de verdade, meus mestres. Lia-os com volúpia, aprendendo como forjavam eles um texto que me induzisse a crer em seus inventos. Percebi, cedo, que para armar uma estrutura narrativa, não bastava talento. A ele era mister aduzir trato literário com a palavra, com a emoção, que a epopeia secreta do texto filtra, definir o tempo que é simultaneamente sutil e pesado, entrelaçar espaços e ação, aprender a pensar enquanto cria, sem perder de vista a carnalidade misteriosa dos personagens. Jamais esquecer que a ilusão, de qualquer parágrafo, tem por fim convencer o leitor de que é ele cúmplice da nossa odisséia narrativa. (PIÑON, 2005)

Neste fragmento, pode-se perceber que o ambiente de liberdade favoreceu 0 processo de escritura, demandando não somente a sensibilidade e criatividade do autor ao captar o momento ápice (imaginação/ficção ou realidade) cotidiano, mas a efetiva participação do leitor na arte milenar de seduzir, encantar, fantasiar e fabular histórias que contribuem para a compreensão do mundo e construção do próprio intelecto, resgatando valores que possam estar perdidos e/ ou esquecidos pela sociedade.

Considerando essa observação, reportamos uma outra explicação a respeito da atitude ativa e participativa concedida ao leitor por Nélida Piñon, presente em uma conversa com Clarice Lispector (1975, p. 193) referente à leitura da sua obra:

Não sou uma escritora que injeta anestesia nos circuitos mentais do leitor. Exijo que ele participe do meu esforço em criar formas novas, todos nós integrados na aventura de ampliar e enriquecer o repertório humano. Acredito porém que a possível distância entre escritor e leitor seja provisória. Em breve defasagem que se elimina à medida que o texto é descosido e se insere à linguagem e necessidade do leitor sempre em desenvolvimento. Não se pode esquecer que o artista é um veloz andarilho no tempo, com propriedade de antecipar-se à sua época, razão de dever aguardar que o leitor dirija-se ao seu texto e o interprete. 
Consciente do poder da linguagem nos discursos orais e escritos, a escritora desenvolve em nós leitores a quota da humanidade, na medida em que nos permite realizar de forma compartilhada uma interpretação e compreensão da sociedade que nos circunda. Portanto, o processo de distanciamento entre autor e leitor está abolido desde o momento em que se cria um horizonte de expectativas e se estabelece um pacto dialógico capaz de inseri-los como integrantes na própria história, ou melhor, como sujeitos mais conscientes de seu papel social enquanto experiência humana.

Considerando este posicionamento sob o prisma da estética da recepção, Queiroz (1997, p. 33) afirma que

\footnotetext{
[..] o leitor só pode fazer falar um texto, isto é concretizar em uma significação atual o sentido potencial da obra, se ele inserir sua compreensão do mundo e da vida no quadro de referência literária implicado pelo texto. Esta precompreensão do leitor inclui as esperas concretas correspondentes aos horizontes de seus interesses, desejos, necessidades e experiências tais como são determinadas pela sociedade e a classe a qual ele pertence, bem como por sua história individual.
}

Assim, cabe ao leitor do texto literário preencher "os vazios" deixados na tessitura textual e construir sua própria interpretação, inserindo seu conhecimento de mundo e suas experiências para ampliar seus horizontes e, consequentemente, potencializar o sentido da obra.

Nessa mesma linha reflexiva se inscrevem as palavras de Nélida Piñon proferidas em entrevista a Bruno Garschagen (2007): "a humanidade não pode prescindir da literatura. A literatura constrói sentimentos que não teriam outro lugar onde se encastelar", pois permite saber, ser, conhecer e conviver, cinzelar encontros e reencontros sob novos olhares e perspectivas.

Para Nélida, pode-se dizer que a literatura é "uma marca de amor, pois ela nada me deve, mas eu devo tudo a ela" (PIÑON, 2005) e, assim, revela uma combinação extraordinária entre o visível e o invisível, o sagrado e o profano, já que permite a circulação pelo mundo, pelos personagens, pelas psiques mais variadas, e assume a sua condição feminina de transitar por todos os lugares, estar em todas as coisas, metamorfosear-se porque o escritor é este ser policênico e polifônico que apresenta 
sua visão de mundo para que possamos ousar com base em nossa reflexão e discussão, pois, "se a natureza humana de fato se alterar, será porque os indivíduos conseguiram olhar para si mesmos de uma maneira mais conscientes. Aqui e acolá pessoas estão tentando fazer isso - muito poucas pessoas, mas alguns romancistas entre elas" (FORSTER, 1969, p.134).

Portanto, a interpretação de uma obra permite visualizar uma força potencializadora perante os atos e relações humanas, uma vez que a vida exige imaginação e, sem ela, não seríamos nada ou apenas vegetaríamos. Por isso, a obra de Nélida como um todo oferece considerável contribuição à estética e, em geral, à literatura, por refletir o pensamento artístico e crítico de uma fase do pensamento da humanidade.

\subsection{PARA ALÉM DAS FRONTEIRAS BRASILEIRAS: REPERCUSSÕES E CRÍTICAS}

Nélida Piñon marca uma significativa presença na literatura nacional e internacional. A repercussão de suas obras reflete o estilo sensível que habita o espaço interior e invade o mundo por meio de metáforas criativas que se tornaram um leit motiv de seu consistente labor literário, ao almejar um lugar inédito no universo da escrita. $^{2}$ Assim, foi acolhida com louvor para compor a presidência da Academia Brasileira de Letras, em 1997. Desta maneira, a sociedade reconhece a atuação da mulher brasileira que inovou a literatura brasileira com as virtudes que ornam a vivência concreta da alma feminina, mantendo-a numa posição de elevado prestígio perante alguns talentosos homens de letras do País.

É incomensurável o número de prêmios literários com que foi contemplada e das publicações que consolidaram sua trajetória no Brasil e em nível internacional, como nos Estados Unidos, Canadá, Holanda, Hungria, Índia, Israel, Kuwait, México, Noruega, Peru, Portugal, República Dominicana, Reino Unido, Suécia e Espanha.

\footnotetext{
${ }^{2}$ Em anexo, encontra-se uma lista de obras críticas sobre o trabalho de Nélida Piñon. (ANEXO 1)
} 
Escritores renomados, bem como periódicos literários e jornais de circulação seletiva vêm ornamentando suas colunas com palavras encomiásticas à grande dama das letras brasileira. Assim, o New York of Books aponta Nélida como "a maior escritora brasileira". O periódico Publichers Weekly menciona que "a imaginação de Nélida a coloca na categoria de gênio."

Um dos magnos nomes da Literatura Latino-Americana, o escritor mexicano Carlos Fuentes, enriquece os comentários acima ao declarar: "a magia de Nélida Piñon consiste em aliar imaginação e compaixão, para dar a seus personagens e seus leitores uma pele com temperatura igual à deles".

Segundo Dixon (2002, p. 201), a prosa de Nélida Piñon "não é para leitores passivos, pois insiste em ressaltar seu tecido verbal, ora com figuras poéticas de grande força lírica, ora com frases que simplesmente nos desafiam pela opacidade".

$\mathrm{Na}$ verdade, a autora faz uso de inúmeros artifícios para instigar e fisgar o leitor, a ponto de muitas vezes deixá-lo sem chão, ou seja, desestruturá-lo com o poder da linguagem, porém, busca comprometê-lo integralmente na interpretação da obra como um todo coerente e significativo.

Para o referido teórico, nota-se uma convergência para o olhar feminino nas narrativas de Nélida Piñon, em especial, em Vozes do deserto, pois ressalta o valor do processo, do meio, como uma experiência que deve ser prolongada, tendo em vista que se tornou um aspecto visível da questão da mulher que transcende a própria realidade em busca de novas experiências, da liberdade e do lugar da diferença no mundo pósmoderno.

Nélida obteve um reconhecimento no pronunciamento da decisão final do prêmio Príncipe de Astúria, título este que nunca fora atribuído a um brasileiro. Nessa ocasião, concorreu ao lado dos escritores norte-americanos Paul Auster e Philip Roth e do israelense Amos Oz. O evento foi presidido por Victor García de la Concha, diretor da Real Academia Espanhola da Língua (RAE), o qual afirmou que Nélida tem sido aclamada pela crítica como a voz mais destacada da literatura brasileira, que transportou no âmbito universal a complexa realidade da Ibero-América.

A revista norteamericana World Literature Today não podia deixar passar em branco o seu posicionamento e, assim, publica uma resenha sobre Vozes do deserto, 
obra que também colocará Nélida entre os 20 escritores indicados para o Prêmio Portugal Telecom de Literatura Brasileira, ao lado de Moacyr Scliar, por ela ser uma das escritoras mais criativas da Língua Portuguesa.

$\mathrm{Na}$ opinião de Celso Furtado, "pelas mãos firmes de Nélida, atrevemo-nos a enfrentar o desconforto da paixão de inventar, conscientes do preço pela inexcedível liberdade de criar".

Para a pesquisadora Naomi Moniz (1993, p. 46), a escritora Nélida é uma figura singular, an odd woman out, que não pode ser enquadrada em nenhum grupo particular, pois, tanto no espírito como no tom, seu percurso é revolucionário, por ela desafiar os canônes literários, eregindo mundos autônomos, com suas próprias leis e estruturas e tomando o texto como símbolo e encarnação imaginária do real. Desta maneira, o que caracteriza sua obra é um desejo de subverter a sintaxe oficial por meio do trabalho com a linguagem, de maneira a atingir um público leitor mais amplo e crítico e desvelar-Ihe os enigmas e mistérios que há por detrás das palavras.

A crítica Nelly Novaes Coelho (1993) diz que a obra de Nélida se situa em mundos proibidos, denuncia os sistemas estratificados e não se contenta com um status criador simplificado, capaz de escravizar o homem no que diz respeito ao seu pensamento, suas palavras e ações. Daí a recusa das sintaxes consagradas e a busca do insólito e do novo.

Reconhecidamente severo em suas avaliações culturais, o jornal parisiense $L e$ Monde assinala que "Nélida Piñon aparece, sem contestação, como um dos maiores temperamentos da cultura brasileira, não hesitando jamais em se engajar em todas as formas de luta para consolidar sua originalidade" (Citação retirada da $4^{a}$ capa - verso do livro Tempo das frutas, 1997).

Com relação ainda ao New York Times Books Review (2005), colhe-se o comentário judicioso: "Nélida Piñon fez de sua república não apenas aqueles de uma família, mas de todo o Brasil e talvez de toda a América Latina".

De acordo com os escritores Daniel Balderston e Mike Gonzalez em Encyclopedia of Latin American and Caribbean Literature, 1900-2003, Nelida Piñon (2003, p. 438) "[...] is linked closely to such contemporary Spanish American writers like Gabriel García Márquez, Mario Vargas Llosa, Isabel Allende and Elena Garro". 
Neste âmbito, importa realçar que o que diferencia Nélida desses escritores é a manipulação intencional do espaço para dar especificidade a uma nova (re)definição da mulher, pois ela está inconformada com a questão da "rotulação" das escritoras feministas, mas é através de um profundo autoconhecimento que é capaz de transmitir a experiência de alteridade/gênero. Desta maneira, Nélida resume a preocupação da mulher brasileira com a reconstrução de uma linguagem significativa, a fim de elucidar aquilo que está censurado pela sociedade, ou seja, a sua intimidade, os sentimentos, as emoções e os desejos, dando um novo conteúdo e forma à própria realidade feminina e humana.

Por sua vez, Giovanni Pontiero (2005) observa que o talento criativo de Nélida Piñon está fora de questão e os fios condutores da imaginação pelos quais ela surfa carregam uma refrescante nota de ironia e de otimismo subentendido.

Apesar de ter sido considerada, no início de sua carreira, como uma escritora de elite, hermética e difícil, ela apresenta um estilo único, muito Nélida "Tout court", como se lê numa crônica de Clarice Lispector, publicado no JB, em 1969, em que é ressaltada a originalidade da obra da escritora.

Nesta perspectiva, nota-se que a direção artística de Nélida não pode ser apreendida sem recurso à imaginação. A realidade parece interpor-se, mas a autora obtempera que "a realidade na qual acreditamos é a convencional... Eu sou contra a convenção, ela pode por em dúvida tudo. Com a imaginação não se aceita o dogma, ela destrói a convenção. O poder tem pavor à imaginação... Cada vez que o poder agrilhoa o homem, a imaginação o liberta". Pode-se dizer que este aspecto marcante de Nélida inscreve o caminho da transgressão, ou melhor, o reino da liberdade para mulheres que tornar-se-ão donas do seu próprio destino.

Segundo o exigente Washington Post, a escritora é "romancista de inegável estatura internacional". Cabe lembrar, novamente, o escritor mexicano Carlos Fuentes, que, entre outros elogios, a chama de "uma peregrina sábia e sorridente".

Para o jornalista João Castello de O Estado de S. Paulo, Nélida é visualizada como "escritora madura, em plena posse de seus instrumentos e que não se sente prisioneira dos ditos 'temas brasileiros', circulando com desenvoltura pelos grandes desfiladeiros da cultura universal" (PIÑON, 2005). Nesse sentido, ele ainda ressalta 
que: "Nélida é uma fada moderna. E, pode-se dizer que sendo fada asperge focos de luz sobre a presidente do Conselho Nacional das Mulheres, Rosiska Darcy de Oliveira, que a considera como "uma humanista na preservação da língua portuguesa e da cultura brasileira".

Ademais, Nélida tornou-se o esteio dos direitos humanos e, particularmente, o direito das mulheres ao quebrar paradigmas impostos por uma sociedade patriarcal, sendo promovida como a melhor escritora pelo New York Review of Books e pelo Journal World Literature, em 2005.

Para finalizar, toda essa explanação serviu para configurar o universo literário de Nélida, que não abriga fronteiras à conduta feminina e à imaginação humana. É o reino da palavra que abre alas para a mulher, para a liberdade e para a fantasia. E, assim, rompe com a tradição literária da época, uma vez que a crítica acolheu sua obra distinguindo-a com títulos de elevado peso cultural nacional e internacional.

\subsection{O ESTADO DA QUESTÃO: A (RE)SIGNIFICAÇÃO DE VOZES DO DESERTO}

Ao investigarmos a produção literária de Nélida Piñon, verificamos que o romance Vozes do deserto, publicado em 2004, ainda não fora objeto de estudo mais alentado, mas somente de trabalhos pontuais e isto favorece a exequibilidade desta pesquisa.

Vozes do deserto, entretanto, representa um marco da literatura contemporânea de autoria feminina, pois, como assevera Darcy de Oliveira (1993), a universalidade da obra está em ampliar a idéia do feminino "mulher" para muito além das fronteiras brasileiras e, ao mesmo tempo, conseguir estabelecer analogias com mulheres de todo o mundo.

Desta maneira, Nélida Piñon mergulhou no mundo Oriental, precisamente em Bagdá, para fazer aflorar daquelas areias finas a mulher de todos os tempos - a Scherezade do mundo "moderno". 
É interessante notar que por "moderno" deve-se atentar para a definição estabelecida pelo pesquisador, historiador e crítico Nicolau Sevcenko (1992, p. 228), como a palavra-origem, o novo absoluto, a palavra-futuro, a palavra-ação, a palavrapotência, a palavra-libertação, a palavra-alumbramento, a palavra-reencantamento, a palavra-epifania. Assim, ela introduz um novo sentido à história, capaz de alterar o vetor dinâmico do tempo que revela sua índole não a partir de algum ponto remoto no passado, mas de algum lugar no futuro. Por isso, o passado é revisitado e revisto para autorizar a originalidade absoluta e garantir a identidade de mulher-sujeito no futuro, dotada de muito mais independência, autonomia e liberdade de expressão e ação.

Convém lembrar que, atualmente, escreve-se muito sobre o retorno de narrativas já conhecidas e consagradas pela crítica e isto se justifica como uma forma de (re)interpretação e ou (re)invenção literária, visando-se novos olhares e perspectivas para a mulher, bem como para a historiografia contemporânea.

Cabe, então, destacar algumas pesquisas sobre o romance Vozes do Deserto, trazendo à luz vozes que mergulharam no mundo da escrita, com intuito de rever a situação da mulher na contemporaneidade. Assim, merecem destaque as pesquisadoras Roberta F. Villibor e Lúcia O. Zolin (2008), que desenvolveram um trabalho primoroso no âmbito do Projeto de Pesquisa "Literatura de Autoria Feminina: Identidade e Diferença" na Universidade Estadual de Maringá (UEM), ao apresentar a comunicação intitulada "Literatura de Autoria Feminina e Reescrita: A Scherezade de Nélida Piñon". O objetivo das autoras foi apresentar uma leitura do romance Vozes do deserto, tendo em vista a estratégia da reescrita desenvolvida pela escritora.

Assim, Villibor e Zolin demonstram que a protagonista de Vozes do deserto, a exemplo de outras heroínas de romances contemporâneos de autoria feminina, ao invés de aparecer enredada nas relações de gênero, desempenhando papéis sociais que a identifiquem como mulher-objeto, é construída como mulher-sujeito, capaz de delinear a própria trajetória e desafiar as manifestações de poder de ideologias dominantes, como a patriarcal.

Em relação à questão da reescrita, Bonnici (2000) a define como uma estratégia em que "o autor se apropria de um texto metrópole, geralmente canônico, problematiza 
a fábula, os personagens ou sua estrutura e cria um novo texto que funciona como resposta pós-colonial à ideologia contida no primeiro texto" (BONNICI, 2000, p. 40).

A partir desse processo de reescrita, a personagem Scherezade é vislumbrada e construída não como uma mera mulher-objeto, mas como a mulher-sujeito, que decide sua própria trajetória ao desafiar as manifestações de poder de ideologias patriarcais dominantes. Desta maneira, as autoras estabeleceram uma articulação entre o texto $O$ livro das mil e uma noites (JAROUCHE, 2006) e o texto da obra estudada que também é o corpus desta dissertação. Portanto, não há como não reverenciar o trabalho, em especial, de Lucia Zolin no que concerne à representação da mulher na narrativa de Nélida Piñon.

Outro trabalho a ser contemplado nessa mesma linha de pesquisa é o de Mariana Miguel (2007), que traça uma breve aproximação entre o romance Vozes do deserto e O Livro das mil e uma noites (JAROUCHE, 2006). Neste estudo, a pesquisadora não mediu esforços para estabelecer a diferença entre ambas as narrativas.

Por fim, Miguel ainda aborda outras dimensões como a questão da impregnação da violência e da dominação masculina acirrada sobre o ser do sexo oposto, o feminino. No entanto, é por intermédio da personagem feminina que o desfecho revela-se surpreendente e positivo, ao corrigir o comportamento humano/alheio.

É necessário destacar outro trabalho de Miguel (2008), que retrata "O caminho da não-violência" abordado por personagens femininas, respectivamente, em duas obras: os romances góticos da escritora inglesa Charlotte Dacre e o romance Vozes do deserto da escritora brasileira Nélida Piñon. Neste estudo, a pesquisadora estabelece uma análise comparativa entre ambas as narrativas, buscando uma melhor compreensão da situação da mulher (escritora ou não) nos vários contextos ao longo da história. Assim sendo, o intuito é subverter e anular a ordem hegemônica vigente nas sociedades, em prol de um olhar diferenciado que somente se consagra através da literatura.

Como se pode observar, segue a proliferação de estudos sobre o romance Vozes do deserto, agora, na voz de Gislene Teixeira Coelho (2005), que analisa a obra, focalizando o trabalho de reescritura e de criação de Nélida Piñon a partir da 
refabulação de As mil e uma noites. Nesse trabalho, foi destacada uma reescritura que se empenha em recolher um material negligenciado, um assunto velado.

O estudo de Maria L. O. Andrade (2007) também merece destaque por analisar a questão da mulher e da memória em Vozes do deserto. Apesar de serem distintas, essas categorias entrecruzam-se e justapõem-se no discurso da obra, bem como no discurso de autoria feminina, já que a tradição da narrativa deve muito à força criativa das mulheres de todas as épocas.

Partindo dessa premissa, nota-se que a obra de Nélida resgata as histórias de As mil e uma noites sob a sensibilidade de um olhar que diverge da visão estereotipada de mulher frágil e submissa que foi configurada na memória coletiva durante anos. É válido observar que o entrelaçamento entre memória, identidade e mulher perfaz e atualiza os discursos sobre gêneros, na medida em que esses fatores constituem o atual discurso de ficção literária produzida por mulheres.

Cabe ainda ressaltar o trabalho de Carine Isabel Reis (2008) intitulado "A magia da narrativa: uma leitura de Vozes do deserto, de Nélida Piñon”. No romance de Nélida, a estudiosa analisa a narrativa como uma forma de conhecimento humano, tema central da sua pesquisa. Ademais, faz-se necessário acrescentar que seu objetivo é difundir a concepção de leitura de narrativas enquanto uma atitude potencializadora no processo de formação e conhecimento na cultura humana.

Maria Teresa Horta (2004) escreveu um artigo intitulado "Xerazade, a dona das palavras que pronuncia". A autora revela que o romance Vozes do deserto pode ser visto como uma homenagem à literatura e à sua sedução, através da visitaçãoredescoberta das ficcionistas-contadoras de histórias. Então, tem-se uma inventiva recriação de As mil e uma noites, a qual vislumbra a personagem Xerazade como uma nova heroína que, com o poder da arte narrativa, liberta-se das interdições impostas ao destino de mulher que ela almeja transformar. Assim, pode-se dizer que ao leitor está reservado o direito de viajar em um tapete mágico e percorrer os dois universos narrativos para assimilar uma melhor compreensão das particularidades, aproximações e diferenças estabelecidas entre ambas as histórias.

Considerando, ainda, os fios das pesquisas existentes, reportamos ao trabalho "Eros da fala, o mito da criação e a identidade do feminino em Vozes do deserto"(2005) 
de Maria Alice Aguiar. A pesquisadora apresenta um estudo intertextual a partir do tema de As mil e uma noites, assinalando a importância do mito na realidade presente, pois se institui como matriz fundamental de toda essência humana capaz de promover saberes, impulsos, afetos, gestos, emoções, sofrimentos, desejos, sonhos e fantasias. Sem dúvida, o processo de criação literária é restaurado através do mito, da fala, em especial, da feminina e sua universalidade, pois perpassa as diversas culturas históricas e sociais ao reviver conteúdos arquetípicos atemporais. Nesse sentido, somente uma autêntica obra de arte é capaz de reviver e suscitar, no âmago do ser humano, as mais inusitadas sensações e experiências num mundo sem fronteiras para a imaginação, como está configurado no romance estudado.

Para finalizar esta parte, vamos ressaltar o trabalho de Lúcia Regina Lucas Rosa (2008) sobre os contadores de histórias em dois romances: $A$ república dos sonhos e Vozes do deserto, de Nélida Piñon.

A pesquisa de Rosa permite evidenciar, nos respectivos romances, as marcas de oralidade e a atuação dos contadores de histórias. Apesar de essas obras terem sido publicadas em épocas diferentes, elas priorizam a narrativa sob a influência de um narrador-contador que domina a estrutura, bem como a vida das personagens envolvidas nesse contexto. Além disso, garantem a discussão sobre a perpetuação de clãs familiares e de costumes de determinados grupos sociais por meio de histórias inventadas e outras lembradas.

Portanto, neste capítulo tratamos, cronologicamente, a vida e obra de Nélida Piñon como representação de escritora no século XXI, enfatizando aspectos que vão desde a arte da criação literária até as repercussões e críticas que envolveram a sua trajetória no âmbito nacional e internacional. E, a partir daí, resenhamos alguns estudos críticos sobre o romance Vozes do deserto, para comprovar a significação desta obra no universo literário brasileiro bem como garantir a perpetuação do mito de Scherezade na história, conforme está abordado no próximo capítulo. 


\section{CAPÍTULO 2}

\section{A PERPETUAÇÃO DE UM MITO:}

DA SCHEREZADE ORIENTAL ATÉ A SCHEREZADE BRASILEIRA

Eu penso em As mil e uma noites: falava-se, narrava-se até o amanhecer para afastar a morte, para adiar o prazo deste desenlace que deveria fechar a boca do narrador. 


\title{
2.1 DE VOLTA AO TÚNEL DO TEMPO: REVENDO O PASSADO DA ARTE MILENAR DE CONTAR HISTÓRIAS
}

Durante anos de nossa existência, viajamos como peregrinas "anônimas" por terras distantes e desconhecidas, sussurrando palavras que emanam de corações andarilhos em busca de visibilidade e reconhecimento na história literária.

No entanto, entre resistir e identificar-se, persistimos nesta longa trajetória e aportamos em um universo fantástico e maravilhoso, onde tudo ocorre ao mesmo tempo, agora. Então, percebe-se que não há mais a dimensão temporal e o espaço territorial é desvelado por um mundo de mulheres audaciosas que, apesar de ainda pouco explorado pela crítica literária, possibilitou propagar a arte da palavra como um instrumento mágico capaz de transmitir valores e atribuir novos sentidos à humanidade.

Neste âmbito, buscar-se-á elucidar as vozes de mulheres que, desde outrora, se fizeram presentes e que se constituem como corpus de pesquisa nas universidades, bem como nas diversas áreas do conhecimento, embora muitas delas ainda continuem desconhecidas no tempo e no espaço. Desse modo, Schmidt (1993) complementa o assunto ao afirmar:

\begin{abstract}
A teoria e a crítica feminista situam-se no quadro de Reconceptualização do campo epistemológico das Ciências Humanas através de paradigmas teóricos e discursivos que desconstroem a concepção normativa da cultura e seus códigos, uma vez que se ocupam das relações de poder e das amarras ideológicas embutidas nos mesmos, reivindicando a construção do sujeito feminino como sujeito do saber, da história, da produção cultural. (SCHMIDT, 1993, p. 180)
\end{abstract}

A partir desse pressuposto, nota-se a relevância dada pela contemporaneidade a tudo aquilo que diz respeito à mulher, pois ela trouxe a lume não somente o conhecimento quer seja da história, política e cultura, mas o tom, o ritmo e a dicção da 
voz feminina na literatura e, consequentemente, no mundo, apesar de ter sido severamente criticada pelo poder dominante ideológico patriarcal.

Observando essa trajetória, pode-se dizer que foram as vozes de contadores de histórias, especificamente, vozes femininas, que fizeram circular histórias que estimulavam o imaginário, na medida em que funcionavam como antídoto para o corpo/alma das pessoas que as ouviam, inserindo-as no mundo das letras ou, por melhor dizer, no mundo literário desde a mais tenra idade.

A apresentação desse aspecto é primordial para que possamos compreender que a arte de narrar/contar histórias tem séculos de existência, pois o ato de contar e ouvir histórias faz parte da existência do ser humano e pode-se dizer que é o que nos distingue dos outros animais.

Entretanto, faz-se necessário saber que mulheres (vozes) são estas que, desde os tempos primórdios, já contavam/narravam histórias? Que atualizações fizeram (fazem) na tessitura do texto que as inscreveram (inscrevem) na contemporaneidade? Que público tenciona buscar tal narrativa? E qual a finalidade de (re)contar uma história clássica?

Com base nessas indagações que atingem até mesmo os pesquisadores e especialistas da área, entramos no túnel do tempo, no qual pudemos evidenciar que a mais remota referência à atividade de contar histórias encontra-se no Górgias, de Platão, que se refere, de forma depreciativa, a um tipo de conto - mythos graós, que significa conto das velhas - narrado pelas amas com o intuito de divertir e/ou assustar as crianças (WARNER, 1999).

Por esse viés, aspergimos focos de luzes sobre as imagens femininas, ou melhor, sobre as deusas, Musas do Olimpo, filhas de Zeus que se predispunham a dizer as primeiras palavras ao poeta Hesíodo: "Pastores, habitantes dos campos, tristes opróbrios da terra que nada sois além de ventres! Sabemos contar mentiras exatamente iguais à realidade; mas sabemos também, quando queremos, proclamar verdades" (COSTA, 2004, p. 10). Eis a arte que compõe o mundo ficcional.

Para Tattar (2004), contar histórias, até o século XVII, filia-se a uma tradição narrativa que fluía especialmente pela fala das mulheres camponesas que, reproduzindo histórias do folclore, manifestavam sua inconformidade com os valores 
feudais. Assim, contar histórias aproximava-se do universo feminino cerceado por enigmas, mistérios e fantasias.

Nesta perspectiva, Walter Benjamin (1994) contrapõe a visão anterior e ressalta que o material a ser narrado provém essencialmente de acontecimentos vivenciados na vida concreta ou imaginária. Então, da origem do material a ser contado, advêm dois tipos de narradores: o camponês sedentário e o marinheiro ou comerciante, isto é, os contadores de histórias dividem-se entre aqueles que permanecem em casa e aqueles que perambulam. Desta maneira, camponeses e marujos foram os primeiros mestres em narrar e os artífices aperfeiçoaram a técnica.

Convém salientar, ainda, que o estudo de Benjamin sobre o narrador na obra de Leskov trouxe reflexões que direcionaram vários trabalhos acerca da oralidade, pois a voz do narrador é o elemento primordial para dar vida ao universo ficcional narrado, bem como a uma linguagem subjetiva.

Seguindo a linha tênue desse pensamento, Warner (1999) afirma que Walter Benjamin ignora as mulheres como contadoras de histórias, desconsiderando a figura da fiandeira. No entanto, esta figura, a partir dos contos publicados por Charles Perrault, tornou-se um ícone da narrativa dos contos de fadas, por ser associada, analogicamente, ao costume europeu de as mulheres contarem histórias enquanto "fiavam e/ou desfiavam", durante os longos serões. Então, quanto à fiandeira pode-se atribuir suas raízes às Parcas da mitologia pagã, as deusas encarregadas de tecer a vida dos homens.

Nesse sentido, é interessante notar, ainda, que a imagem da fiandeira está configurada desde antes da Idade Média, pois o ato de fiar, com roca e fuso, foi sempre associado à mulher, isto é, vinculado ao poder feminino de tecer novas vidas e garantir o abrigo dos corpos.

Diante desses pressupostos, pode-se dizer que é de outrora o interesse pela revelação dessas vozes que, a priori, enalteciam o dom de difundir a palavra com o intuito de marcar presença na história.

Assim, a natureza feminina compunha o cenário de investigações, ligadas ao âmbito literário ou não, que alçavam, gradativamente, patamares superiores, ao 
instaurar a mulher como sujeito ativo e participativo na história e isso, seguramente, incomodava o universo masculino.

Desta maneira, a ideia de transitar na herança cultural do Oriente ao Ocidente possibilitou uma compreensão do orientalismo, configurado por Said (2001) como o estudo do Ocidente sobre o Oriente para o esclarecimento de aspectos como a formação de identidade, cultura e história.

Para Said (2001, p. 33), o Oriente é uma ideia que tem história e uma tradição de pensamento, imagística e vocabulário que Ihe deram realidade e presença no e para o Ocidente. Portanto, a relação entre Ocidente e o Oriente é uma relação de poder, de dominação, apresentando graus variados de uma complexa hegemonia. O autor esclarece, também, que o Oriente foi um terreno fértil de investimentos, pesquisas e teorias, com o intuito de desvendá-lo de uma forma que pudesse fortalecer e/ou favorecer o poder ocidental.

Nesta âmbito, Said (2001, p. 35) propõe fazer com que o orientalismo atual faça o estudo de alternativas contemporâneas, isto é, "que investigue como se podem estudar outras culturas e outros povos a partir de uma perspectiva libertária, ou não representativa e não manipulativa".

Adentramos justamente na cultura desses povos por meio da voz de uma peregrina (Scherezade), para entender as vivências humanas porque, de outra forma, não poderíamos alcançar entendimento/conhecimento e, ao mesmo tempo, desmistificar preconceitos sobre a mulher naquela cultura e na nossa, em especial, na literatura produzida por mulheres.

Nesta perspectiva, na literatura brasileira, pode-se dizer que foram as negras que se tornaram, entre nós, as grandes contadoras de histórias (FREYRE, 1998, p. 330), tendo em vista que habitavam as senzalas ou as casas grandes, onde desempenhavam o papel de "amas-de-leite" ou "mães criadeiras", cuja função era de difusora e perpetuadora da literatura oral para as crianças.

Segundo Gilberto Freyre, as amas negras eram contadoras hábeis e criativas, pois possuíam um amplo repertório de contos orais, desde as histórias européias trazidas pelos colonizadores portugueses, passando pelas tradições indígenas e 
africanas até as histórias que elas mesmas inventavam ou simplesmente adaptavam à cor local ou regional.

O crítico literário Silvio Romero (1985), no final do século XIX, ressalta em seus estudos, a presença das contadoras de histórias e homenageia a sua ama negra chamada Antônia, ao recordar o seu tempo de menino num engenho do Norte.

[...] Devo isso à mucama de estimação a que foram, em casa de meus avós, encarregados os desvelos de minha meninice. Ainda hoje existe, nonagenária, no Lagarto, ao lado de minha mãe, essa adorada Antônia, a quem me acostumei a chamar também de mãe. (ROMERO, 1985, p. 354)

Apesar dessas reminiscências, o crítico menciona a dificuldade de precisão sobre a origem étnica das histórias orais que estavam em circulação no Brasil, devido à mistura e alteração que elas sofreram quando foram transplantadas para a nossa terra (ROMERO, 1985).

É interessante notar que outros brasileiros da geração de Silvio Romero também ressaltaram a presença das velhas contadoras de histórias ou rezadeiras, como é o caso do próprio Joaquim Nabuco que, porventura, aprendera com a sua velha ama negra de Maçangana o padre-nosso que, no fim da vida, voltou a rezar na Igreja do Oratório, em Londres.

Convém lembrar, ainda, o escritor José Lins do Rego que, na sua obra Menino de engenho (1991), fala das velhas estranhas que apareciam pelos banguês da Paraíba: contavam histórias e depois iam-se embora. Ademais, o autor faz referência à apropriação criativa das histórias orais européias por meio de uma das mais antigas contadoras de histórias de sua infância, a velha Totônia:

Ainda me lembro hoje da velha Totônia, bem velha e bem magra, andando, de engenho a engenho, contando as suas histórias de Trancoso. Não havia menino que não lhe quisesse um bem muito grande, que não esperasse, com o coração batendo de alegria, a visita da boa velhinha, de voz tão mansa e de vontade tão fraca aos pedidos dos seus ouvintes. (REGO, 1991, p. XI) 
De acordo com as palavras do escritor, esta personagem andava "léguas e léguas a pé, de engenho a engenho, como uma edição viva de As mil e uma noites. $\mathrm{Na}$ verdade, era "o que fazia a velha Totonha mais curiosa", conforme explicita o autor:

[...] era a cor local que punha nos seus descritivos. Quando ela queria pintar um reino era como se estivesse falando de um engenho fabuloso. Os rios e a floresta por onde andavam os seus personagens se pareciam muito com o Paraíba e a mata do Rolo. O seu Barba-Azul era um senhor de engenho de Pernambuco. (REGO, 1991, p. 38-39)

Aliás, é a partir da voz dessa personagem, bem como de suas histórias, que o autor enfatiza a importância de ouvir e contar histórias, revelando um reino encantado repleto de imaginação e fantasia, que fascina as futuras gerações. Assim, abrir-se-ão os caminhos para o mundo literário infantil através da leitura e publicação da obra Histórias da Velha Totônia (1981).

Considerando este posicionamento, Freyre também mencionara, em CasaGrande \& Senzala, a personagem Scherezade como aquela negra e sem dentes da infância do escritor e amigo Lins do Rego, a qual, na sua opinião, era uma versão brasileira do "Akpalô".

O vocábulo Akpalô nos remete à ideia de fazedor de alô ou conto. Na verdade, foi uma instituição africana que floresceu no Brasil, representada por negras velhas que viviam indo de engenho em engenho, contando histórias às outras pretas, criadeiras (amas) dos meninos brancos.

Assim, pode-se dizer que as narrativas orais/escritas possibilitam ao ouvinte/leitor compreender e, ao mesmo tempo, resgatar histórias de experiências passadas, tendo suas matrizes inseridas tanto na tradição quanto no cotidiano e salientando o processo de luta pela maior visibilidade de um grupo cultural, em especial, o feminino. Desse modo, buscar-se-á esclarecer os fatos "camuflados" que ficaram registrados na memória e que nem sempre são perceptíveis, mas sempre têm algo a acrescentar, quer seja uma informação, uma dica, uma sugestão, um conselho e até uma crítica diante desse processo silencioso de interpretação. Por isso, não há 
como não repensar a importância da presença feminina nas narrativas orais tradicionais nas culturas atuais, tendo em vista que colaboraram para a conscientização e formação do ser humano, ao atribuir um novo sentido para a vida.

Atrás dessa percepção, retomamos uma reflexão de Wolfgang Iser (1979), que salienta que a obra literária mais eficiente é aquela que força o leitor a uma nova consciência crítica de seus códigos e expectativas habituais, pois, se modificamos o texto com nossas estratégias de leitura, ele simultaneamente nos modifica: como os objetos de um experimento científico, ele pode dar uma "resposta" imprevisível às nossas "perguntas". Por isso, toda a função da leitura é levar-nos a uma autoconsciência mais profunda, catalisando uma visão mais crítica de nossas identidades e da própria experiência humana.

Para complementar este aspecto, citamos Benjamin (1994) que afirma que o narrar implica intercâmbio de experiências, pois o ato de contar é vital para a constituição tanto de quem fala como de quem escuta:

\begin{abstract}
A experiência que passa de pessoa a pessoa é a fonte a que recorreram todos os narradores. E, entre as narrativas escritas, as melhores são as que menos se distinguem das histórias orais contadas pelos inúmeros narradores anônimos. (BENJAMIN, 1994, p. 198)
\end{abstract}

Benjamin salienta, ainda, que "narrar uma história implica em descontração e o ouvinte quanto mais se esquece de si mesmo, mais profundamente se grava nele o que é ouvido" (BENJAMIN, 1994, 205).

De acordo com Costa (2000), narrar é uma forma de exteriorizar a existência individual e coletiva, é a expressão da temporalidade humana (COSTA, 2000, p. 43), pois a narrativa constrói uma história, integra duração e temporalidade de maneira que todos os seres humanos possuem a mesma capacidade de narrar seu cotidiano, sua existência, seus percalços, seus desejos e suas vontades de mudança. E, assim, ao realizar isso, constroem suas identidades individuais e, como estão inseridos juntos no mesmo contexto, em uma mesma cultura, passam a edificar as identidades coletivas. 
Desta maneira, quando os indivíduos narram, ou até mesmo, escutam narrativas, acionam suas memórias, resgatam tradições, questionam valores, crenças, ideologias e ética e, ao mesmo tempo, exercem o poder de construir múltiplas identidades individuais e coletivas.

A construção dessa visão individual e, simultaneamente, coletiva nos remete a explicação fornecida pelo escritor e crítico Antonio Candido (2000), que considera a maneira de narrar a existência do eu no mundo particularizadora, de um lado, na medida em que destaca o indivíduo e seus casos, mas, de outro, generalizadora, porque é simultaneamente descrição de lugar e biografia de grupo.

Segundo Forster (1969), a questão do narrar é uma característica humana muito antiga, que envolve processos mentais complexos como compreender o sistema simbólico, as reminiscências e a imaginação. Cabe lembrar que todo esse processo desencadeado na compreensão de uma narrativa instiga sentimentos subjetivos, pois faz parte de um processo maior que é o da criação, produto da própria experiência humana do autor. Por isso, muitas vezes, o leitor mergulhado no mundo das palavras se identifica, ou melhor, se encontra na história, o que exige dele uma nova visão e interpretação do mundo no qual está inserido. Desta maneira, o autor conclui que "a sufocante qualidade humana do romance não deve ser evitada; o romance está encharcado de humanidade" (FORSTER, 1969, p.17), aspecto que contribui para fisgar o leitor e instigá-lo a interpretar a obra como um todo coerente e significativo.

Apesar disso, é interessante notar a visão de Walter Benjamin (1994) e Gilberto Freyre, os quais mencionam que tais narrativas estão cada vez mais escassas, ou seja, em vias de desaparecimento. Este posicionamento não se refere à quantidade de narrativas existentes, mas ao número de pessoas que sabem narrar bem e confirma que "é como se estivéssemos privados de uma faculdade que nos parecia segura e inalienável: a faculdade de intercambiar experiências", uma vez que "são cada vez mais raras as pessoas que sabem narrar devidamente" (BENJAMIN, 1994, p.198).

Nos dias atuais, é lamentável que o papel de contador de histórias se restrinja, muitas vezes, somente à escola e, consequentemente, às professoras, pois se sabe que muitas dessas vozes femininas já desempenharam tal papel em diversas épocas 
da História, tendo-se Scherezade como uma das figuras mais emblemáticas desta prática, em todos os tempos.

A esse respeito, Nélida Piñon tornou-se esteta ao apresentar em Vozes do deserto um mundo a ser explorado, uma abertura reflexiva na amplitude de visões futuras diante da vida que, por intermédio da sua prodigiosa imaginação, vem suprir, salvaguardar e, ao mesmo tempo, resgatar a velha presença das contadoras de histórias do "passado recente", que, incorporadas na imagem da mais ardilosa personagem da literatura universal chamada Scherezade, conseguiram também tocar a sensibilidade de diversos outros autores da literatura brasileira, conforme já foi abordado, bem como de outros da literatura estrangeira, que estão mencionados no próximo item.

Por outro lado, é válido lembrar que estudos mais recentes como os de Rowe e Schelling (1991) contestam a visão decadente da cultura oralizante mencionada anteriormente, apontando várias modalidades populares que permaneceram intactas, bem como outras que se modernizaram, sendo, inclusive, apropriadas e revitalizadas pela escrita e pela cultura de massa como é o caso do cinema, rádio, televisão e até a Internet.

Nesse sentido, pode-se dizer que, mesmo com todo o arsenal tecnológico e a difusão dos livros, o ofício do contador de histórias não desapareceu, manifestando-se sob diferentes perspectivas, tais como as canções de ninar cantadas por nossas mães e avós, as histórias transmitidas às crianças, as parlendas, adivinhas etc. (MEIRELLES, 1984).

Diante desse posicionamento, é plausível afirmar que, consciente e coerente com a visão da sociedade contemporânea, Nélida parece enfatizar a importância dessas contadoras/narradoras de histórias no universo literário brasileiro, como um fecundo desenvolvimento pessoal e intelectual que, com certeza, contribui para a formação da consciência feminina nacional deste país, bem como para estabelecer o vínculo entre outras mulheres do mundo, ao "pincelar" notas de fantasia na vida de cada uma delas.

Segundo Forster (1969), a personagem Scherezade desviou seu fado porque sabia manejar a rama do "suspense", o único instrumento literário que possui qualquer 
efeito sobre tiranos e selvagens. [...] Ela sobreviveu unicamente porque conseguiu manter o rei imaginando o que aconteceria depois. Cada vez que via o sol nascendo, ela parava no meio de uma frase, deixando-o boquiaberto: "Nesse momento, Scherezade viu a manhã surgindo e, prudentemente, silenciou" (FORSTER, 1969, p. 20-21).

Diante dessa afirmação, é possível admitir que a personagem referida tem em suas mãos o poder de conduzir a mente do ouvinte até o ponto de envolvê-lo e deixá-lo sem palavras, ou melhor, boquiaberto e preso à narração, pois "a cada noite Scherezade envolve o Califa em teia sutil. [...] mantendo o interesse do Califa até o amanhecer" (PIÑON, 2006, p. 35). Assim, "a matéria da imaginação, que estremece os seus sentidos, tem a voz como conduto. A cada noite, o seu timbre, milenar, repercute na fantasia e nas palavras que vão dando corpo a seus enredos" (PIÑON, 2006, p. 129).

Este ato pode guiar o ouvinte mais por um viés positivo do que negativo, ao suscitar as expectativas que mexem com seu intelecto e, ao mesmo tempo, aguçam a curiosidade de querer ouvir e saber sempre mais e mais. Por isso, a personagem decide suspender a história em pontos estratégicos, em pleno raiar do dia, para que ela consiga fisgar, 'olho no olho', a atenção do ouvinte, garantindo, assim, mais um dia de existência à narradora.

Dessa forma, Piñon, imbuída do papel de intelectual, propulsora, difusora e perpetuadora da tradição literária oral, consegue resgatar imagens femininas como eixo temporal e espacial, demarcando sua significação e posição ao longo de uma ideologia que tende a negá-las pela tradição. Assim, ressalta a figura da mãe, da filha, da irmã, da esposa, da amante, da empregada, da escrava, da narradora, da contadora, da escritora, da artista, da personagem, da leitora e, acima de tudo, da mulher que estabelece o vínculo entre outras mulheres, mantendo um elo de importante ligação entre gerações.

Em concordância com este pensamento, Ecléa Bosi (1987), em Memória e sociedade, afirma que "a história deve reproduzir-se de geração a geração, gerar muitas outras, cujos fios se cruzem, prolongando o original, puxado por outros dedos", que, no nosso caso, são os dedos de fada da escritora Nélida. 
Portanto, diante das novas exigências e conquistas sociopolíticas e culturais, a mulher precisa se libertar das amarras patriarcais para validar sua posição de sujeito enunciador da palavra em prol de uma vida digna e de maior visibilidade, afastando-se das imposições absurdas configuradas por uma sociedade estereotipada que delegara à mulher um lugar "restrito e incerto" na história da humanidade.

\subsection{O ETERNO RETORNO: AS MIL E UMA NOITES}

No limiar do século $\mathrm{XXI}$, o momento é oportuno para retornar ao livro As mil e uma noites, narrativa de aventuras fantásticas e sedutoras que se eternizou no tempo e no espaço, em prol de uma maior reflexão do ser humano, visando novos paradigmas.

Nesse sentido, o sucesso dessa obra possibilitou vislumbrar, além das mil e uma histórias, um eixo fulcral que gira em torno da relação homem-mulher, por ela abordar temas arraigados à natureza humana, em especial, no que diz respeito à mulher. Assim, atribuir-se-á à mulher o poder da palavra como ato vital para sua sobrevivência física e espiritual, bem como para a realização socioeconômica e afetiva. Juntamente com essa percepção, outros temas vêm à tona como o amor, o ódio, a morte, a vingança, a inveja, a traição, a injustiça, o casamento, sexo, exaltação do erotismo, entre outros, para que o leitor possa buscar um nexo mais profundo por detrás das palavras escritas, uma vez que estas se eternizaram no tempo com o intuito de propiciar o verdadeiro sentido da vida.

Considerando este posicionamento, pode-se dizer que esta obra serviu como referência e fonte de inspiração para diversas obras literárias, teatrais, cinematográficas e artísticas, bem como para inúmeros escritores de todas as partes do mundo: na França, Antoine Hamilton, Thomas Simon Guellette, Crébilon Fils, Denis Diderot, Jacques Cazotte Voltaire; na Inglaterra, Joseph Addison, Samuel Johnson, William Beckford, Horace Walpole, Robert Southey, Samuel Coleridge, Thomas De Quincey, George Meredith e Robert Louis Stevenson; na Alemanha, Wilhelm Heinrich Wackenroder, Friedrich Schiller, Wilhelm Hauff e Hugo Von Hofmannsthal e, finalmente, 
na América, Washington Irving, Marcel Proust (SIC), Machado de Assis, Edgar Allan Poe, Herman Melville, Jean Potocki, Jorge Luis Borges e, finalmente, Nélida Piñon (ZIPES, 2007).

De acordo com o filósofo francês Michel Foucault, essa narrativa é "o avesso encarniçado do assassínio, é o esforço de noite após noite para conseguir manter a morte fora do ciclo da existência" (JAROUCHE, 2006, p. 9).

Acompanhando essa árdua trajetória, observa-se que o livro de As mil e uma noites é fruto dos decoros das épocas em que foi elaborado ou reelaborado. Por isso, grandes são as especulações referentes às origens (árabe, síria, persa, india, grega, egípcia etc.) e também as supostas alterações que permitiram o florescimento das mais inusitadas histórias e os finais mais surpreendentes dessa obra.

Convém enfatizar que As mil e uma noites é uma das primazias do fabulário Oriental e deve ter sido completada em fins do século $X V$, mas chegou ao conhecimento do mundo Ocidental somente no início do século XVIII, conforme explicita Coelho em sua obra O conto de fadas: símbolos, mitos, arquétipos (COELHO, 2008, p. 40).

Segundo Zipes (2007, p. 53), esta obra foi traduzida, primeiramente, para o francês, entre 1704 e 1717, pelo orientalista francês Jean-Antoine Galland (1646-1715). Essa tradução, desde então, repercutiu em toda a Europa e, posteriormente, na América do Norte e no restante do mundo.

Em consonância com o referido autor, Wajnberg (1997) salienta que Antoine Galland realizou essa primeira tradução para o francês a partir de uma adaptação de um manuscrito árabe do final do século XIII, ou talvez, do início do século XIV.

É válido observar que, para Wajnberg, a maioria dos contos presentes nesta obra têm raízes nas culturas hindu e persa. Esta afirmação se justifica devido ao fato de o historiador e antologista Mas'ûdi, que viveu entre os anos de 896-956, ter mencionado, nos seus estudos sobre a cultura muçulmana na Idade Média, um livro árabe chamado Hasar Afsanah (As mil histórias extraordinárias). Apesar de as histórias nele contidas serem de origem persa, este livro foi traduzido em árabe, ficando conhecido como Alf laylah wa-laylah, ou melhor, As mil e uma noites. 
De acordo com Wajnberg, este exemplar apresenta um conto-moldura como o de As mil e uma noites e, portanto, convém resumir o entrecho nas palavras de Zipes:

[...] story of a caliph who kills his wife because she betrays him. Then, for the next three years, he takes a new wife and slays her each night after taking her maidenhead to avenge himself on women. He is finally diverted from this cruel custom by a vizier's daughter, assisted by her slave-girl (ZIPES, 2007, p. 56)

[...] a história de um califa que mata sua esposa porque ela o traiu. Então, no decorrer de três anos, ele toma uma nova esposa toda noite matandoa após tirar sua virgindade para vingar-se das mulheres. Ele é, finalmente, interrompido deste hábito cruel pela filha do Vizir, assistida por sua escrava. (ZIPES, 2007, p. 56, tradução nossa).

O autor referido salienta que, no percurso de longos séculos, vários contadores de histórias, escritores e estudiosos fizeram uso dessa estrutura e, desde então, começaram a registrar os contos desta coleção e outros, moldando-os isoladamente ou dentro da narrativa de Scheherezade/Shahriyâr. Desta maneira, os contadores e autores das histórias eram anônimos e seus estilos e linguagem divergiam muito. Todavia, a característica comum é o fato de que foram contadas em uma linguagem coloquial chamada médio árabe, com gramática e sintaxe peculiar.

É válido notar que, por volta do século XV, havia três camadas distintas que podiam ser detectados na coleção daquelas histórias que formaram o núcleo do que ficou conhecido como as As mil e uma noites: (1) contos persas, em que havia alguns elementos da Índia que foram adaptados para o árabe no século $X$; (2) contos registrados em Bagdá entre os séculos X e XII; e (3) histórias escritas no Egito, entre o XI e XIV século.

Wajnberg (1997, p. 70) afirma, ainda, que o livro As mil e uma noites apresenta uma pluralidade pela influência de diferentes povos (origens), culturas, conteúdos e, ou até mesmo, adaptações ao longo dos anos, deixando-se a critério daquele que conta/narra as devidas alterações na narrativa. Nesse sentido, pode-se dizer que essa 
"demiurgia" nos remete ao velho ditado de que "quem conta um conto aumenta um ponto".

[...] as Noites seriam uma obra anônima, construída por diversas camadas sobrepostas, num processo de muitas e várias passagens, que implicam em remanejamentos e adaptações nos seus vários momentos. Esta hipótese parece sustentar com suficiente verossimilhança a evidente heterogeneidade de elementos e estilos, correspondentes a diversas épocas, onde a existência de muitos manuscritos acusaria inclusive a pluralidade das pátrias do Livro. (WAJNBERG, 1997, p. 65)

Ademais, a autora revela que essa narrativa denota uma dupla compilação, oral e escrita, e que esse encadeamento de histórias dentro de outras, ou melhor, contos dentro de outros, é uma característica dos povos islâmicos, conforme exemplifica a seguir:

[...] as Noites seriam uma obra de compilação de dupla origem, para a qual concorrem narrativas transmitidas oralmente pelos contadores de histórias e, por outro lado, obras escritas que posteriormente foram integradas à coleção. A tradição de escritura desse gênero de narrativas - seja ela inaugurada pelos persas... é retomada pelos árabes, ou melhor pelos seus autores já reconhecidos e confirmados como mestres da língua. Teremos, a partir desse primeiro remanejamento pelos árabes entre a metade do século VIII e o início do século IX, um tipo de "romance" designado pelo termo ajzá, literalmente traduzido como "partes" caracterizado por tomos separados que comporiam uma soma de contos numa obra comum. (WAJNBERG, 1997, p. 70)

Com base no fragmento acima, observa-se uma combinação da narração (oral/escrita) que foi compilada ao longo da história pelos vários autores, em especial, entre os séculos VIII e IX, período este que nos permite vislumbrar a literatura de pura invenção, imaginação e criação, configurada tanto no reinado do lendário califa Harum Al-Rashid, quanto em Vozes do deserto. 
Considerando a trajetória de As mil e uma noites, Wajnberg faz uma síntese em relação à composição textual dessa obra:

\begin{abstract}
[...] 1) surgimento do mercado cultural árabe de contos de origem persa ou transmitidos pelo Irã, a partir do meio do século VIII; 2) atividade registro, paralela à de inúmeras outras obras, durante as próximas décadas, com a intervenção da figura de Harum alRachid e a devida atestação histórica desta atividade para o início do século IX; 3) aclimatação definitiva dos contos durante todo o século IX, com a participação dos árabes desde o seu tesouro cultural com o acréscimo de outras histórias, como a aventura marítima de Sindbad; 4) adaptação potente e bem sucedida destes contos para o universo árabe-islâmico, de forma que figurem escritos, lidos e conhecidos - na adad do homem civilizado do século X. (WAJNBERG, 1997, p. 66)
\end{abstract}

Evidentemente, as palavras da autora vêm comprovar as influências das diversas origens e das diferentes edições ao longo da história. Com certeza, estes aspectos propiciaram as devidas transformações (cultura, personagens, geografia etc.) da história tida como "original ou moldura", para que pudesse perdurar até hoje como fonte de referência e inspiração na narrativa oral e/ou escrita. Assim, as histórias estão de volta, lançadas no tempo e no espaço fértil para verterem novos olhares e perspectivas, em especial, na literatura produzida por mulheres.

Neste âmbito, dentre as inúmeras coletâneas que circularam ao longo dos séculos, merecem destaque as cinco principais edições árabes do livro As mil e uma noites, que comentamos a seguir.

1 - A primeira edição, denominada Calcutá, foi publicada, respectivamente, em dois volumes, entre 1814 e 1818, pelo editor Ahmad Bin Mahmûd Sirwâni Alyamãnî. Era baseada no manuscrito Arabic 6299, do Índia Office Library, em Londres. Trata-se de uma edição raríssima, com uma introdução escrita em persa, que ainda pode ser consultada. É uma primazia para quem almeja aprender árabe e imergir nessa cultura.

2 - Já a segunda edição recebeu o nome da própria cidade alemã em que fora publicada, Breslau. Assim, foram totalizados doze volumes entre 1825 e 1843, sendo os oito primeiros sob a responsabilidade de Maximilian Habicht e os outros quatro sob a 
responsabilidade do Heinrich Fleischer. Essa edição apresenta a peculiaridade de ser a primeira "completa", isto é, composta de mil e uma noites. Todavia, foi considerada uma "falsificação" e suas variantes serviram de base para que Jean-Antoine Galland pudesse realizar os acréscimos e modificações em sua tradução, no início do século XVIII. A edição foi republicada em fac-símile no Cairo, em 1998.

3 - Outra edição a ser mencionada é a de Bulaq (Bulak), publicada em 1835 no Cairo, em dois volumes. Na verdade, trata-se da primeira edição baseada em um único manuscrito falho e sem revisão do ramo egípcio tardio, com os mesmos 'defeitos' apresentados nos próprios originais. Entretanto, uma obra importantíssima para o estudo das transformações operadas no livro de As mil e uma noites, que aliás, foi republicada em edição fac-similar em Beirute, em 1997.

4 - Neste âmbito, convém lembrar, ainda, a segunda edição de Calcutá (Calcutá II) composta de 4 volumes, publicados, entre 1839 e 1842, por William H. Macnaghten. Apesar de essa edição ser baseada no ramo egípcio tardio, não tem nenhuma relação com a primeira já mencionada, exceto a cidade em que fora impressa. Além disso, foi republicada em fac-símile no Cairo, entre 1996 e 1997, em oito volumes.

5 - Por fim, há uma edição crítica do ramo sírio denominada Leiden. Foi publicada em 1984, em dois volumes, sob a responsabilidade do crítico e filólogo Muhsin Mahdi. A edição é referência obrigatória para os pesquisadores do assunto. $O$ referido crítico fez uso tanto do manuscrito mais antigo baseado em Galland, quanto dos demais manuscritos do ramo sírio e egípcio, destacando os níveis de linguagem para a verossimilhança da narrativa.

De acordo com os estudos de Gomes (2000), o esforço de traduzir As mil e uma noites gerou diversas versões da narrativa árabe, repercutindo no Ocidente, de maneira que é possível identificar as principais versões em ordem cronológica.

Primeiramente, Hammer-Purgstall (1774-1856), na Alemanha, encontrou um manuscrito em que o sultão Schariar arrepende-se da suas ações e perdoa sua esposa Scherezade. Pode-se dizer que este é o final mais conhecido de todas as histórias, embora estejam perdidos o manuscrito e a tradução alemã.

Depois, Edward Lane, inglês, desenvolveu um trabalho que consta de um vasto detalhamento do cotidiano e do vocabulário árabe, no período de 1828 a 1849. 
Posteriormente, surge outro inglês chamado John Pane (1842-1906), que traduziu versos e alguns contos eróticos.

Outro estudioso que merece ser destacado é Richard Burton, que pesquisou de forma aprofundada as diferentes culturas orientais e também possuía um domínio de várias línguas tribais. Ademais, sua obra é considerada erudita e apresenta muitas notas explicativas que contribuem para uma melhor compreensão do contexto.

No que concerne ainda à tradução, cabe lembrar tanto o francês Mardrus (18681949), que reforçou e aprimorou o caráter erótico do texto, quanto o alemão Enno Littmann (1875-1958), que apresentou uma tradução em que não constam os poemas do original, mas é considerada uma obra de boa qualidade.

Para finalizar, convém mencionar um estudo realizado por Jorge Luis Borges (1999) sobre as traduções de As mil e uma noites, uma vez que, para ele, essas diferentes versões e traduções são provenientes de textos árabes que sofreram influências e modificações ao longo dos anos. Portanto, "As mil e uma noites não são uma coisa morta. Trata-se de um livro tão vasto que nem é preciso lê-lo. Ele é parte prévia de nossa memória" (BORGES, 1983, p.88).

Diante do exposto, nota-se a contribuição de inúmeros pesquisadores e tradutores para abrilhantar a magia da criação narrativa de As mil e uma noites, ao manterem em chamas a fascinação de adentrar nesse mundo fictício e vivenciar novas aventuras e experiências que, com certeza, enriquecerão a vida cotidiana, na busca de transformação do próprio ser, pautado ou não por dados da história, pois esta é cíclica e nos remete ao eterno retorno, marcado por novas visões e interpretações, em um tempo infinito.

Nesta perspectiva, passamos a refletir de maneira meticulosa sobre a representação da personagem Scherezade e isto nos instigou a ir além dessa leitura e a transgredir a realidade, visto que "a gente tem vontade de perder-se em As mil e uma noites, pois sabe que, se entrar nesse livro, é capaz de esquecer nosso pobre destino humano" (BORGES, 1983, p. 81). 


\subsection{AS RECRIAÇÕES DE SCHEREZADE}

Apesar de existir uma apreciável quantidade de histórias nos séculos IX, X, XII, XIV, XV, XVIII, XIX e, inclusive, o século XXI sobre Xerezade, Sherazade, ou ainda, Scherezade, Sahrazad, há muita polêmica entre pesquisadores, historiadores e tradutores acerca de diversos fatos referentes a aparição dessa princesa contadora das Mil e uma noites, entre os quais a revelação da grafia do seu nome, a precisão do local e o ano de seu surgimento e sua autoria, uma série de lacunas, questionamentos enigmáticos e misteriosos que sugerem outras e novas interpretações.

Ademais, já lhe atribuíram as origens árabe, síria, grega, indiana e, inclusive, persa. Assim, essa repercussão resultou do enorme interesse e curiosidade para averiguar a construção da personagem Sahrazad (grafia do ramo sírio, traduzida por Jarouche, 2006) e descobrir um mundo feminino oculto a ser descortinado pela humanidade. Desta maneira, as pesquisas e investigações contribuíram para disseminar a popularidade de narrativas produzidas por mulheres, ao retomarem uma das obras clássica da literatura universal intitulada As mil e uma noites.

Faz-se necessário enfatizar que as histórias sobre a princesa e um rei circularam de boca em boca do Oriente ao Ocidente, durante centenas de anos, antes de serem escritas. Na verdade, essas histórias orais preenchiam o imaginário, tornando-se fonte inesgotável de conhecimento e inspiração para enfrentar a realidade cotidiana.

Então, ao percorrer um panorama histórico sobre as narrativas de As mil e uma noites, deparamo-nos com a tradução de Mamede Mustafá Jarouche (2006), uma obra vertida do ramo sírio que reúne "fábulas de terror e de piedade, de amor e ódio, de medos e de paixões desenfreadas, de atitudes generosas e de comportamentos cruéis, de delicadeza e sutilidade" (JAROUCHE, 2006, p. 9) e que já sofreu inúmeras transformações, constando ser uma obra escrita por muitos e que não pode ser de ninguém (JAROUCHE, 2006, p.11).

Desta maneira, o tradutor compilou várias versões manuscritas e impressas em árabe para captar o ritmo, a melodia, o tom e a dicção da fala dos personagens e 
manter viva a questão da originalidade, evidenciando seu profundo conhecimento da língua árabe e da cultura oriental.

É uma história surpreendente que comunica ao leitor os fatos acontecidos antes mesmo de ele adentrar na primeira noite. Assim, numa espécie de "prólogo", o leitor toma ciência da traição da esposa do califa com um escravo do palácio. Ademais, revela-se que, entre as criadas, há homens disfarçados de mulheres para copular com as mulheres do califa na ausência deste.

O rei Sahriyar, desiludido e inconformado com semelhante desventura ocorrida ao seu irmão mais novo Sahzaman, entra em uma "paranóia desvairada" para saber se existe no mundo outro ser tão infeliz. Numa viagem, os irmãos frustrados com a infidelidade das esposas avistam um ifrit, espécie de entidade maligna, que carrega um baú de vidro com quatro cadeados de aço. No entanto, quando os cadeados são abertos, surge uma linda mulher que, com um pequeno sinal, faz adormecer o gigante e, posteriormente, obriga os dois irmãos a copularem com ela, exigindo os seus anéis como trunfo para poder contabilizar o número de homens que já havia seduzido e dominado, pois "quando a mulher deseja alguma coisa, ninguém pode impedi-la" (JAROUCHE, 2006, p. 48).

Diante dessa situação, ao retornar ao palácio, o califa decide casar-se cada noite com uma nova esposa, mandando-a para o verdugo na manhã seguinte, ou seja, para a morte, numa tentativa de "salvaguardar sua alma" dos pecados carnais cometidos por essas mulheres infiéis e pecaminosas, já que para ele "não é mesmo possível confiar nas mulheres!" (JAROUCHE, 2006, p. 40).

Então, neste ambiente sombrio e repleto de atrocidades, somente uma mulher sábia, resoluta e astuta como Sahrazad, filha do Vizir, cujo pai devia servidão ao poderoso Sultão, seria capaz de se sujeitar ao casamento para pôr fim a uma série de assassinatos que se instauraram no califado por causa da traição da Sultana. Apesar de ter decepcionado e contrariado a opinião do seu pai, Sahrazad diz: "Eu gostaria que você me casasse com o rei Sahriyar. Ou me converto em um motivo para a salvação das pessoas ou morro e me acabo, tornando-me igual a quem morreu e acabou" (JAROUCHE, 2006, p. 50). Então, como não houve meios para dissuadi-la dessa 
tomada de decisão, o ato se consuma. E, consequentemente, a vida de mais uma mulher parece estar por um "fio" tênue que pode the reservar um destino incerto.

Desta maneira, Sahrazad elaborou um plano meticuloso de contar histórias "sem fins" para garantir sua própria sobrevivência e das demais mulheres do reino. Essa "armação" foi colocada em prática graças ao auxílio de Dinarzada, sua irmã, que proporcionou a inserção da primeira história a ser contada durante a noite do enlace, bem como a continuidade dela(s) ao explicitar: "Minha irmãzinha, se você não estiver dormindo, conte-me uma de suas belas historinhas com as quais costumávamos atravessar nossos serões..." (JAROUCHE, 2006, p. 56).

É interessante notar que, noite após noite, Sahrazad tece os fios narrativos para consolidar sua trama e envolver, definitivamente, o Sultão na sua teia. Assim, ao contar as mais mirabolantes histórias, ela consegue deixar em suspenso algumas partes para entrelaçá-las no dia seguinte e, consequentemente, salvar a própria pele e manter viva e aguçada a curiosidade do ouvinte. Então, é o desejo de ouvir as histórias inacabadas que prorroga a vida da narradora e das demais jovens pelas quais ela se sacrifica.

Considerando todo esse percurso, nota-se que o foco recai sobre as histórias que Sahrazad conta ao Califa para entretê-lo e fazer com que se cumpra sua missão de contadora de histórias, pois, a cada narrativa, ela consegue validar a palavra que se perpetua e isto significa o adiamento da morte. Nota-se que as histórias tornaram-se fonte de prazer, de sensualidade, de ação, de aventura, de fantasia, de imaginação e de pura diversão (entretenimento) para ocupar parte do tempo ocioso.

Muito embora essas histórias façam parte da tradição oral e do imaginário coletivo, não há uma maior preocupação em retratar a personagem de uma forma mais íntima e aprofundada, apesar de esta promover o prazer, o encanto e o valor na arte de narrar histórias para o Califa e para seus descendentes.

Neste âmbito, não escapa às mãos do pesquisador e aos olhos do leitor o intento de visualizar a personagem Sahrazad por outro viés que a distingue daquele já exposto, para instaurá-la no mundo ficcional abordado por Nélida, disponibilizando um texto que percorre as veredas do feminismo, narra e apresenta um universo que particulariza e, ao mesmo tempo, pluraliza as mulheres de todos os tempos e lugares, tornando-as libertas das interdições impostas ao destino feminino que Nélida almeja 
transformar, afastando, desse modo, qualquer tipo de preconceito, submissão, opressão, violência e até a morte.

\subsection{SCHEREZADE EM VOZES DO DESERTO}

Vozes do deserto de Nélida Piñon se inscreve dentro da Literatura Brasileira de Autoria Feminina Contemporânea, possibilitando vislumbrar a mítica personagem Scherezade como o protótipo ativo mais recente de toda a eternidade humana, ou melhor, como a mulher-sujeito que transgride as fronteiras físicas e espirituais para encontrar a razão de ser e de estar no mundo, pois "[...] Quem tem ouvidos ouça - é a palavra que resta dizer ao leitor desta obra que reinventa o fascínio das Mil e uma noites" (BOSI, contra-capa de Vozes do Deserto, 2006).

É válido observar que, apesar de Nélida realizar uma re-leitura dessa história, ela não a menciona em nenhum dos 64 capítulos que totalizam as 351 páginas do romance. Nota-se apenas uma breve menção na contra-capa da obra, conforme citação acima, realizada pelo escritor e crítico Alfredo Bosi.

Neste âmbito, ao adentrarmos no romance, já embarcamos no tapete mágico guiado pelas mãos de Nélida, sem obter qualquer tipo de informações, dados ou fatos preliminares que ocorreram anteriormente à história do Califa. Então, aportamos no mundo Oriental, precisamente Bagdá, local onde a escritora faz renascer uma das mais ardilosas contadoras de histórias da humanidade, chamada Scherezade, em sua essência, mulher, e esta tem a oportunidade de desfrutar, sem medo e sem rodeios, a abertura da narrativa, bem como de conduzir o leitor ao mundo da imaginação e da fantasia.

Scherezade não teme a morte. Não acredita que o poder do Mundo, representado pelo Califa, a quem o pai serve, decrete por meio de sua morte o extermínio da sua imaginação... Quer opor-se à desdita que atinge os lares de Bagdá e arredores, oferecendo-se ao soberano em sedicioso holocausto. (PIÑON, 2006, p. 7) 
Neste contexto, Scherezade assume o papel de protagonista, narradora, personagem e até testemunha dos fatos e acontecimentos ocorridos no reino, de modo que as cenas giram em torno dela e do outro de forma direta ou indireta, como uma tentativa para protelar o quadro de morte e transformar o comportamento humano. É ela quem efetua a travessia do Califa para o mundo da fantasia e da sensatez, de valores morais, éticos e religiosos.

A personagem, desde as suas primeiras aparições, é apresentada como um ser humano comum e sensível diante da vida cotidiana. Aliás, está provida de todas as características femininas como a audácia, a ousadia, a coragem, a persistência e a força para lutar contra as formas de poderes estabelecidos por uma sociedade patriarcal, que é, nesse caso, representada pelo autoritário Califa.

É justamente dessa maneira que começamos a acompanhar a trajetória de Scherezade e notamos uma maior preocupação com a sua própria história de vida, por ela declarar ser a "única" capaz de pôr um fim à chacina que aterroriza todas as jovens de Bagdá. Então, toma a decisão de se oferecer ao soberano para salvar todas as mulheres do reino, inclusive, a si mesma.

A notícia do sacrifício de Scherezade se alastra pelo califado, perturbando a todos, em especial, o Vizir, seu pai, que discorda da ideia de viver sem a presença da filha. No entanto, tenta persuadi-la para que desista dessa 'insanidade' que a conduzirá, eternamente, a um reino frio e inerte.

Scherezade parece contrariar as imposições e regras estabelecidas pelo sagrado matrimônio e, consequentemente, do patriarcado, ao contrariar a vontade do pai para a consumação do seu enlace com o Sultão. A partir daí, observa-se o início de um embate contra o destino de mulher, aparentemente "frágil e objetificado", que se impõe perante a natureza do sexo oposto com uma voz que destoa daquelas que já se submeteram à mesma situação.

$\mathrm{Na}$ verdade, é um ser que comoveu toda a Medina, ao demonstrar os seus sentimentos pelo próximo, suas emoções, suas dores, enfim, seu sofrimento perante a vida/morte e morte/vida. Assim, a personagem é mais do que humanizada, assume uma significação expressiva de um ser supremo, uma deusa, ao postular as influências 
que esta exerce sobre os humanos ao deixá-los com os olhos prostrados e o corpo estremecido diante da realidade que a circunda.

É válido observar que tudo é revelado intencionalmente: seus sentimentos, suas angústias, paixões, dores, alegrias, tristezas, fantasias, sonhos, sexualidade e, inclusive, seu corpo. Não sente constrangimento ao mostrar os relatos picantes, nem se envergonha das minúcias sexuais. Portanto, não há segredos e tudo é escancarado de tal forma que a autora parece incorporar a imagem da própria personagem, pois fala sobre ela, tanto quanto através dela, ou permite que possamos ouvi-la por intermédio de outras vozes que sussurram em nossos ouvidos, tornando a vida privada/íntima mais convincente e verossímil.

Assim, Nélida tece sua surpreeendente obra-prima ao revelar a vida oculta, íntima e cotidiana na sua fonte mais profunda: conta-nos, sobre a mulher em si e sobre Scherezade, mais do que esta poderia saber e imaginar, como fazer sexo sem amor, obscenamente mecânico e repugnante, imposto à jovem de tal maneira que elucida o abuso de poder, violência e exploração do próprio corpo como algo fútil e efêmero, além da opressão e obsessão conflituosa entre vida/morte. Perante essa situação de confinamento e enclausuramento, Nélida soube extrair da essência feminina a seiva para que se pudesse modificar o efeito da história e, com certeza, garantir a liberdade de expressão e ação, mediante a transformação do ser feminino no tempo e no espaço.

Nesse percurso narrativo, nota-se que o poder decisório de Scherezade é descrito longamente. Assim, ela assume para si o peso de toda uma responsabilidade, sem medir o resultado das consequências que decorrerão deste ato, "talvez" impensado, que se impõe mediante tal decisão, uma vez que ela tem a árdua tarefa de 'suportar' este fardo que o destino ainda lhe reserva. Desta maneira, a sina de Scherezade ganhara notoriedade, refletindo sobre a própria desdita, pois "em torno da jovem floresciam sentimentos na iminência de desembocar em um desfecho trágico" (PIÑON, 2006, p.9) ou, ainda, "próxima vítima da tirania do Califa, ela abstrai-se de tão grave ameaça (PIÑON, 2006, p. 10).

Scherezade não se intimida perante o leito de morte e enfrenta a realidade com a astúcia de quem comanda um cortejo humano, atiçando o poder de fogo de sua 
imaginação uma vez que "sua sina não era vencê-lo na cama, mas superá-lo ao iniciar a primeira história" (PIÑON, 2006, p.19). Aliás, pode-se dizer que a filha do Vizir

[...] descerra para um Califa fatigado o tapete de trama suntuosa, cujos nós e pontas lhe chegam da psique coletiva do povo que ele governa. De uma fonte originária do cruzamento de culturas nômades que atravessam o deserto, as tundras, o espaço geográficos. (PIÑON, 2006, p. 215)

Vale ressaltar que a intenção da personagem é aniquilar o Califa, pois ela sabe melhor do que ninguém o perigo da empreitada de aguçar a curiosidade do ouvinte por meio do ato de narrar, mantendo afastado o medo da morte. No entanto, passa a vivenciar o conflito existencial de servir à vida e à morte.

De acordo com Benjamin (1994, p. 207), é no momento da morte que o saber e a sabedoria do ser humano e sobretudo sua existência vivida findam as histórias, pois "a morte é a sanção de tudo o que o narrador pode contar. É da morte que ele deriva sua autoridade" (BENJAMIN, 1994, p. 208). Neste caso, a concepção de morte pode estar relacionada a um novo renascimento de Scherezade na história, uma vez que, nessa dualidade, 'morte e vida' convivem lado a lado e lutam por espaço na tessitura textual, assim como a personagem Scherezade luta por um espaço de liberdade no mundo.

Então, essa relação angustiante da personagem com a certeza de que a morte se aproxima, a cada dia, um pouco mais faz com que ela vislumbre que a vida e a morte são inseparáveis: são a totalidade que acena para a eternidade, conforme menciona Paz (1982, p. 182):

[...] a morte é inseparável de nós. Não está fora: a morte é nós. Viver é morrer. [...] o viver consiste em termos sido jogados para o morrer, mas esse morrer só se cumpre no e pelo viver. Se o nascer envolve o morrer, também o morrer envolve o nascer; se o nascer está banhado de negatividade, o morrer adquire uma tonalidade positiva porque é determinado pelo nascer. [...] Vida e Morte, ser ou nada, não constituem substâncias separadas. Negação e afirmação, falta e plenitude coexistem em nós. São nós. 
Considerando, ainda, esse viés interpretativo, Morin (1995) salienta que, quando o ser humano descobre a morte, percebe a vida real e imaginária e, consequentemente, precisa aprender a lidar com o tempo, pois é um ser finito na infinitude do tempo e do universo.

Partindo desse pressuposto, pode-se dizer que Scherezade é uma fonte de energia revitalizante, pois tem plena consciência para agilizar, cronometrar e manipular o tempo a seu favor, revelando como personagem e/ou narradora tudo aquilo que lhe convém em prol de uma melhor compreensão da essência humana feminina. Assim, aguça, no sexo oposto, o conhecimento pelo deslumbramento da mente, corpo e espírito, afiançando, com o poder de sua voz inebriante, as virtudes da esposa "perfeita" que, longe de trair o esposo, busca alegrar seu espírito com extraordinárias inovações narrativas. Com certeza, este aspecto despertaria o prazer de ouví-las e, consequentemente, de elevar à eternidade o gosto pela literatura.

Então, vai à luta ajudada pela sua irmã Dinazarda, que leva como prioridade o desenvolvimento de seu projeto de contar histórias ininterruptas para libertar todas as mulheres do sacrifício imposto pelo Califa e, assim, redimir as ações desse soberano, pois as palavras têm o poder de cristalizar e desestabilizar a realidade sobre a qual o Califa governa, vislumbrando outros olhares, outros mundos imaginários.

Nota-se que o poder de concentração exigido naquela primeira noite, "depende da atuação de Dinazarda, pois ambas as irmãs estão enlaçadas pelo mesmo destino e esperam a própria salvação" (PIÑON, 2006, p. 12). A verdade é que Dinazarda "não pode falhar em cumprir a missão de despertar a sonolenta Scherezade após a cópula e convencer o soberano da necessidade de ouvir a história da irmã antes de ordenar sua decapitação" (PIÑON, 2006, p. 15).

Paralelamente, podemos trilhar a participação de mais duas mulheres, Jasmine e Fátima, pois juntas anunciam a união do sexo feminino sob a imensidão do deserto. $\mathrm{Na}$ verdade, todas são mulheres dotadas de poderes, não os sobrenaturais, mas aqueles explicáveis pelas leis naturais em que se faz uso da palavra para alçar voos de liberdade e de sonhos de transgressão, numa realidade que, em parte, as aproxima e distancia do misterioso universo masculino, porém, mantendo as mulheres numa posição privilegiada e de diferença. 
Desta maneira, Scherezade parece estar configurada numa espécie de primeiro plano e converte seu mundo de sonhos, imaginação e fantasia na mais pura realidade, ao dar lugar a outras histórias prestes a desabrochar sob o impulso de seu engenho, inclusive sua história de vida pessoal, que está camuflada sob os véus de uma sociedade famigerada e cheia de barbáries contra as mulheres.

É necessário salientar que, embora as histórias contadas por Scherezade tenham sido herdadas em parte da mãe, de Fátima, e de uma educação esmerada, e sejam também fruto de sua fértil imaginação, tais histórias não têm uma maior repercussão no contexto atual da obra, pois só servem para protelar, ou melhor, adiar mais um dia o risco iminente da morte que ronda o seu ser.

Então, importa salientar que as histórias funcionam como um 'engodo' para aprisionar aquele que pensa que a faz prisioneira, envolvendo-o em suas histórias fantásticas e, consequentemente, libertando-se de seu destino: "A verdade é que o Califa vinha se desligando da administração do califado para viver em função da jovem" (PIÑON, 2006, p. 237).

Nesse percurso narrativo, ao leitor é dado o privilégio de conhecer e compartilhar a realidade que circunda Scherezade, evidenciando a experiência de vida íntima nos seus mínimos detalhes, pois as cenas denotam um erotismo explícito que vai se matizando com força advinda do sexo, como uma rede de revitalidade que deveria surgir da união dos corpos.

[...] O soberano prefere fornicar no escuro. Guia-se pela lamparina que justamente distraí Scherezade das funções amorosas. [...] No entanto, o corpo Ihe arde. Discreta apalpa o sexo, a brecha provida pela passagem do Califa, caído ao seu lado, ambas genitálias em fragalhos. (PIÑON, 2006, p. 103)

Nestas circunstancias, então, seria natural que as coxas de Dinazarda se molhassem com o líquido a escorrer da vulva, fonte inesgotável de prazer, e que, no curso de tal empreitada, friccionasse o sexo na expectativa de Ihe aflorarem estremecimentos, descargas elétricas. (PIÑON, 2006, 20) 
[...] engolfada em poderosa experiência. [...] enquanto a carne, ferida. Parece-lhe gotejar secreções, esperma, em meio a lamúrias suas e do amante imaginário, que se entrecruzam, caóticas. [...] O gosto do sangue, provindo da vulva dilatada, vem-lhe em golfadas. (PIÑN, 2006, p. 22)

Desta maneira, não há pudor de mostrar a "verdade nua e crua", ou seja, a "carne na carne", latejando e pulsando as vibrações do coração e do corpo para elevação do espírito. Então, percebe-se que aquilo que era algo ponderado, aos olhos das pessoas mais conservadoras, como um assunto restrito, sigiloso e privado torna-se público para a sociedade. A partir daí, as mulheres se revelam como sujeitos ativos e participativos na vida masculina e cotidiana, pois sabem o que querem e até aonde podem chegar.

Nessa concepção, Fontes (1995) ressalta que os homens ganham elevação de espírito por intermédio das mulheres:

[...] É assim que a mulher, ao mesmo tempo em que busca sua própria ascensão, funciona como guia no crescimento do homem. Seja como mãe, amante, prostituta ou mestra espiritual, ela é a sacerdotisa que revela, tanto nos ritos, como nos simples gestos cotidianos, sua dimensão mítica. (FONTES, 1995, s/p.)

Scherezade é humanizada a tal ponto que se sente exaurida das suas ações do dia a dia que ganham forma, corpo e alma para resistir nessa trajetória. É uma mulher de fibra e personalidade forte, pois, mesmo com o fardo de se deitar com um homem frio, que não lhe proporciona prazer, consente apenas em fazer cumprir a rotina do sexo sem amor e em servi-lo como uma escrava, conforme descrição abaixo:

[...] A serenidade de Scherezade impressiona-a. Confrontada com aquele corpo que se esvaziara para o cumprimento do seu dever, Dinazarda rejeita a visão do Califa brandir o membro como instrumento de conquista. (PIÑON, 2006, p. 13) 
[...] Scherezade acompanhou o gesto do Califa a desnudá-la da cintura para baixo, com visível desapreço pelos seios. Uma cena cuja evolução, mantendo-a fria a despeito do Califa Ihe arranhar o ventre com as unhas, tanta cautela não lhe protegia o corpo. (PIÑON, 2006, p. 20)

[...] Com o rosto ensombreado, ela enfrenta a tensa pugna, luta por restaurar os tecidos da vida tomando seus personagens como exemplo. Sofre em pensar que seu valor consiste em servi-lo como uma escrava na masmorra, que só existe legitimada pelo soberano. (PIÑON, 2006, p.39)

Neste âmbito, pode-se dizer que as histórias entrarão num segundo plano e sem êxito, uma vez que funcionam apenas para afastar a morte e tentar sorver, até a última gota, o sangue do soberano, a pretexto de aliviá-lo de seu "carma":

[...] Sem ele perceber que a meta da jovem era jamais deixar os fios soltos do relato no ar, de modo a poder atá-los na noite seguinte. Pois sua função, afim de salvar-se, previa considerar o peso de cada palavra na frase, sem esquecer, para isto, de acrescentar ossos, gorduras, paixões aos personagens, fruto de sua invenção. A eles confinando o encargo de abrandar o coração empedernido daquele homem. (PIÑON, 2006, p. 27)

Assim, sofre na própria pele as dores e os desatinos de um destino e futuro incertos, pois luta apenas pela vida, obedecendo ao instinto da aventura narrativa que regava palavras e ativava a sua imaginação para a salvação e/ou transformação.

É certo que Scherezade provou sua engenhosidade verbal ao escolher o mais surdo dos ouvintes, pois estava convencida do poder da palavra, ou melhor, da literatura dando vida a personagens que parecem não se fixar nem no tempo nem no espaço abarcando, porém, as proezas da vida humana.

Possuidora de uma beleza incomum, ressente-se do peso do cativeiro em que vive confinada no palácio, sob a constante ameaça de morte. Esse enfoque a respeito do cativeiro e/ou prisão será retomado no terceiro capítulo deste trabalho. 
[...] Resguardada e ciosa, ela se ressente do cativeiro em que vive no palácio. Razão de sua desabrida imaginação semear ilusões e mentiras. Mas é da prisão também que ela semeia falsas esperanças. Dando a ele motivo diário para ameaçá-la com a morte. (PIÑON, 2006, p.60)

[...] Apregoa-lhe ainda que tenha cuidado, se não der seguidas provas de engenho, ele arranca-lhe o coração, como já fizera com outras. [...] Insinua-lhe que, se falhar, já ao amanhecer a entregará ao verdugo. (PIÑON, 2006, p. 74-149)

[...] Quanto a Scherezade, confinada ao palácio, seu campo afetivo estreitara-se naqueles meses. [...] Escrava de uma morte programada, aguarda que o Califa the recorde a cada aurora que, conquanto possa matá-la, preserva-lhe a vida por breves horas, para ameaçá-la de novo no futuro imediato. (PIÑON, 2006, p. 213)

Scherezade é a dona da palavra que pronuncia, portanto, define a seu bel prazer a trajetória de cada ação, ato e gesto, receando que a vida fuja ao seu controle, pois o menor sinal de descuido pode levá-la a uma execução fatal. Reconhece a importância de sua atividade como contadora de histórias, porém, comunica que se trata de um ofício relegado à obscuridade, não rendoso e, muitas vezes, desprezado pela elite literária. No entanto, esta contadora sabe melhor do que ninguém, brandir os distúrbios e os devaneios que acossam os seus personagens e que afugentam, a cada dia, a vida do Califa, ameaçando encarcerá-lo na eternidade.

Nesse percurso narrativo, nota-se que a sexualidade aparece apenas como um traço distintivo, tendo em vista que a relação que a princesa mantém com o Califa é bem "corriqueira", centrada apenas no "fazer por fazer", sem maiores pretensões, pois não há sentimento afetivo e o amor não passa de uma representação teatral, conforme fica evidenciado no fragmento abaixo.

O amor é teatral, intui Scherezade, que, à mercê do Califa, jamais se apaixonou. O espectáculo amoroso, como o concebe agora, junto ao leito do Califa, requer ilusão, artifício, máscaras coladas aos rostos dos amantes enquanto copulam. (PIÑON, 2006, p. 191) 
Desse modo, cabe dizer que ambos copulam por obrigação e, embora o soberano imponha tirania e demonstre insatisfação, a personagem sai vitoriosa a cada manhã, causando certa decepção ao sexo oposto.

Assim, age e reage com presteza e eficácia ao utilizar a palavra como uma arma, ou melhor, instrumento de poder para asfixiá-lo com as agruras humanas que corroem seu corpo e alma, almejando devolvê-lo à apatia habitual. Além disso, ela não se esquiva de sua feminilidade, abarcando um lado bom, de mulher anjo e um outro lado de mulher meio feiticeira.

Reconhecidamente, perante os olhos do tirano, Scherezade passa a ser a mulher ideal, cuja vida ele poupara a cada amanhecer, cumprindo "em partes" os rituais do matrimônio. Desta maneira, observa-se que ele abandonara o alforje do poder em troca de fantasia, aspirando a ser outro que não ele, usurpando, assim, a identidade alheia por meio do ardil da ilusão, pois "a verdade é que o Califa vinha se desligando da administração do califado para viver em função da jovem" (PIÑON, 2006, p. 237).

Podemos constatar que Scherezade seduz e encanta não pela voluptuosidade do corpo, mas pelo uso que faz da palavra ao dominar entonação, ritmo, cadência e as duas grandes metáforas presentes na história: a relação entre autor e leitor e a própria formação do escritor, ao conceber a sua obra de arte com o poder da imaginação e criação, visto que contribuem para enfeitiçar os amantes das histórias maravilhosas. Desta maneira, a peregrinação verbal leva Scherezade à liberdade sua, do Califa e de muitas mulheres do reino.

Scherezade fora a primeira mulher a pôr fim às atrocidades cometidas no palácio, pois acredita no seu instinto e no poder do discurso feminino. Aliás, aprendera a sobreviver diante das mais diversas situações, conquistando seguidores e leitores, pois ela se tornou mestre no ofício de narrar, fantasiar e fabular. No entanto, é nítido o seu esgotamento físico e mental para dar um fecho às histórias inconclusas. A luta pela sobrevivência é comovente e mostra a trajetória sufocante dessa mulher na vida cotidiana, que acaba por integrar, no próprio ser, uma comunhão de opostos feminino e masculino para atenuar o sofrimento do corpo e da alma na recriação desta personagem. 
Scherezade assume alternadamente papéis femininos e masculinos. Sente-se à vontade em descrever o falo e a vulva. Seu corpo absorve em igual intensidade as proporções de cada qual. Lateja, pulsa, incha, cresce, endurece, segundo a anatomia que representa seus relatos. Quando se cansa de ser homem, esquecida do que é ser mulher na corte de Bagdá, sente desprezo por uma humanidade imersa na sujeira e nas falsas ilusões. (PIÑON, 2006, p. 307)

Desta maneira, ao conviver com essa duplicidade, ela não consegue mais suportar e até mesmo esconder o confinamento em que vive, uma vez que não há nem amor nem prazer, ou seja, nada que a prenda àquele homem do mal, em especial, no coito. A dimensão que toma a situação exige ações e mudanças bruscas para reverter não somente o quadro de matança, a perseguição em relação às mulheres e as constantes ameaças, mas para conseguir a conquista do bem supremo, a liberdade. A partir daí, instaura-se a idealização de um outro projeto em que pode haver perdas e ganhos, mas que poderia libertar Scherezade, de uma vez por todas, do reino da morte.

A ideia de Scherezade colocar outra moça no seu lugar reafirma sua condição de mulher-objeto na relação com o Califa.

[...] Após entrevistar a jovem de nome Djauara, que tremia de medo diante de um destino cruel, aprovou-a mediante recapitulações contínuas do que deveria fazer na presença do Califa. [...] foi introduzida nos aposentos reais, que pisava pela primeira vez. Mostrou-lhe o leito que em que iria copular com o Califa, repassando com ela rapidamente os detalhes finais. [...] E encerrou o rol de conselhos enfatizando como agir agora que se tornara a princesa Scherezade. (PIÑON, 2006, p. 322)

Ao abandonar o palácio, Scherezade tem consciência de poder ser substituída nas suas funções de amante e contadora de histórias. Chegou o momento do Califa viver sem ela, pois para o Sultão pouco Ihe importaria quem estivesse no leito. $\mathrm{Na}$ verdade, ele só queria de Scherezade, o pedaço específico do coração que lhe contava histórias intermináveis.

O surpreendente é que as histórias contadas por Scherezade funcionaram como uma terapia, ou melhor, uma espécie de cura e salvação para a alma daquele ser impiedoso. Neste sentido, o Califa se redime com o poder das palavras que 
transformaram e abrandaram o seu coração, assumindo, em parte, a culpa pelos excessos cometidos, na medida em que deixa Scherezade livre da sentença de morte, para escolher a seu bel prazer, o próprio caminho.

[...] pouco antes do amanhecer, enquanto ela ainda the falava, que, a partir daquela noite, estaria dispensada do seu veredicto. Isto é, não haveria castigo para ela. Estava livre para deixá-lo, seguir para onde quisesse, levando consigo a garantia de nunca mais punir uma jovem de Bagdá. (PIÑON, 2006, p. 341)

Uma vez que Dinazarda e Jasmine tomaram o lugar de Scherezade, ela pode partir em busca de seus sonhos, reencontrar a ama Fátima, enfim, de se libertar, de uma vez por todas, daquele pesadelo que a atormentou por vários anos e que quase a consumiu, para embarcar em uma nova aventura constituída pelo poder da imaginação, uma vez que este nunca se apagaria e deixaria vivenciar novas relações fora da atmosfera masculina.

Portanto, a Scherezade de Nélida diverge daquela concebida pelas recriações anteriores em que está dominada e confinada pela fatalidade imposta pela ideologia arcaica dominante. Esta personagem nova postula a visibilidade de tornar-se, a cada dia, mulher que triunfa sobre o poder, sobre a imaginação e, inclusive, sobre a morte, pois é a voz incomum, mantenedora da literatura e a mulher sujeito de todos os tempos, da arte da criação à arte da palavra, que ousa buscar a sua valorização e transformação em prol de um mundo melhor e mais digno de se viver no futuro. 


\section{CAPÍTULO 3}

OS ENTRELAÇAMENTOS DE PODER, EROTISMO E FEMINISMO

EM VOZES DO DESERTO

A escrita constitui uma prova e como que uma pedra de toque:

ao trazer à luz os movimentos do pensamento, dissipa a sombra anterior onde se tecem as tramas do inimigo. 


\subsection{OLHARES SOBRE A CRÍTICA FEMINISTA: UMA REVISÃO}

Desde as décadas anteriores (60, 70 e 80 ), os debates em torno da condição feminina, ou melhor, questões de mulheres vêm ganhando força e repercussão nas diversas áreas do conhecimento. Isto permitiu que as experiências pessoais e sociais envolvendo a questão de gênero (masculino $x$ feminino) fossem meticulosamente repensadas.

Então, deparamos com o campo da literatura que abriu espaço para que essa temática fosse abordada com prioridade neste trabalho, em especial, a da crítica feminista que questiona a prática acadêmica patriarcal nas suas várias dimensões sociopolítica e cultural.

Nesse sentido, a proposta da crítica literária feminista é realizar uma leitura do texto literário de modo que se possa desconstruir o caráter discriminatório das ideologias de gênero configurado ao longo dos anos. Assim, ao utilizar a terminologia "crítica feminista", faz-se necessário esclarecer, sucintamente, a significação dos termos feminino e feminismo para um melhor discernimento sobre o assunto. No primeiro termo, podem-se evidenciar duas concepções: um sentido puramente biológico e um outro mais complexo como oposição ao masculino, com referência a características atribuídas, culturalmente, à mulher. Já o termo feminismo, que será enfocado de uma forma mais ampla no próximo item, se refere a um movimento que busca alcançar os direitos civis e políticos das mulheres.

Observando essa trajetória, pode-se notar que o feminismo apresenta várias vertentes como a existencialista, a radical, a socialista, a liberal e a política, conforme evidenciado em Feminist Politics and Human Nature, de Alison M. Jaggar (1993).

Neste âmbito, as ideias disseminadas por Simone de Beauvoir (1967) acerca do feminismo existencialista contribuem, de forma sistemática, com os estudos de gêneros empreendidos pela nova geração de feministas, por contemplar, de um lado, um estudo da opressão da mulher na sociedade e, de outro, sugerir formas de emancipá-la dessa situação. Entretanto, a autora salienta que não existe uma essência feminina, responsável pela discriminação da mulher. A discriminação deve-se, segundo esta 
autora, ao fato de que, ao dar à luz e ao manter os cuidados com o bebê e os afazeres domésticos, a mulher vivia em um ambiente social restrito, condição que favoreceu o fortalecimento do estereótipo da superioridade masculina atribuido ao sexo que mata e não àquele que gera a vida.

É interessante notar que o feminismo radical traz duas visões: a primeira é a busca da libertação da mulher por meio da desconstrução de seu papel como reprodutora. A segunda pretende combater os binarismos hierarquizados responsáveis pelo domínio masculino sobre as mulheres, a fim de substituí-los pelo andrógino, um ser humano que está acima das diferenças de sexo.

Por outro lado, cabe lembrar, ainda, que a concepção socialista do feminismo enfatiza que é possível a libertação feminina numa sociedade socialista, de maneira que os princípios de igualdade sejam para todos sem distinção de sexo, cor e raça. No entanto, a tendência liberal do feminismo acredita que essa igualdade de direitos entre homens e mulheres só pode ser garantida por meio da legislação, tendo em vista que a mulher sofrera 'calada e sem direito' ao longo de séculos.

No que concerne à abordagem do feminismo político e, em concordância com Sartre e Beauvoir, Kate Millet (1970) acredita que toda manifestação de poder exige consentimento por parte do oprimido. Para a referida autora, no caso específico das mulheres, as instituições como a família e o Estado seriam os detentores de poder, na medida em que acabaram afirmando, ainda que de maneira contraditória, o poder masculino.

A crítica feminista contemporânea investiga a literatura produzida por mulheres sob quatro enfoques: o biológico, o linguístico, o psicanalítico e o político-cultural, que, embora estejam articulados em torno de investigação e contestação do sistema patriarcal, colaboram para destruir a dominação de um gênero sobre outro.

Considerando o posicionamento de Showalter (1994, p.44) a respeito dos enfoques abordados, pode-se dizer que o enfoque cultural é abordado de forma mais completa devido ao fato de ele atender o contexto sócio-histórico-cultural em que a literatura produzida por mulheres está instituída na sociedade, ao englobar suas experiências e idéias referentes ao corpo, à linguagem e à psique feminina. Paralelamente a este enfoque, não se devem descartar as questões abordadas por 
Julia Kristeva, Hélène Cixous e Luce Irigaray no que concerne à sexualidade, identidade e escrita, pois o diálogo entre as duas vertentes norte-americana e francesa contribuiu tanto para integrar o universo literário feminino, no sentido da investigação e contestação da estrutura patriarcal dominante, quanto para o crescimento do interesse em relação às teorias.

Assim, é possível delinear nosso corpus de pesquisa na proposta de Showalter de uma crítica feminista "ginocrítica", na qual se tem mais a oportunidade de aprender a partir dos estudos da mulher, especificamente da mulher como escritora, mediante a abordagem de diversos aspectos:

[...] a história, os estilos, os temas, os gêneros e as estruturas dos escritos de mulheres; a psicodinâmica da criatividade feminina; a trajetória da carreira feminina individual ou coletiva; e a evolução e as leis de uma tradição literária de mulheres. (SHOWALTER, 1994, p. 12)

Partindo dessa premissa, pode-se dizer que essa proposta expressa o desejo de milhares de mulheres de constituir "uma crítica feminista que seja genuinamente centrada na mulher, independente e intelectualmente coerente" (SHOWALTER, 1994, p. 28). É exatamente neste ponto que será buscado uma maior compreensão da construção das personagens femininas, em especial, Scherezade no romance Vozes do deserto. Assim, confirma-se o desejo tanto por parte da escritora Nélida Piñon quanto da ginocrítica de dar voz àquelas que ficaram silenciadas por muito tempo na historia, buscando-se encontrar na mulher significados e respostas para as suas "próprias verdades" imersas na realidade na qual está ela inserida.

Convém, ainda, enfatizar que Showalter influenciou novas perspectivas nas narrativas de autoria feminina, apresentando três fases: a feminina (1859 a 1944), com ênfase na repetição dos padrões culturais dominantes patriarcais, imitação e internalização dos valores desses padrões vigentes; a feminista (1944 a 1990 aproximadamente), com protesto e ruptura em relação ao modelo patriarcal e, 
finalmente, a mulher (a partir da década de 1990) com autodescoberta feminina e busca de identidade, além de perspectiva existencial ampla.

Portanto, como essas fases serão retomadas no quarto capítulo e não são consideradas categorias rígidas, pode-se dizer que as três permeiam o universo nelidiano com maior e/ou menor grau de intensidade e também podem ser identificadas em literaturas de diferentes tipos e nacionalidades, em especial, na literatura de autoria feminina brasileira.

\subsection{DO FEMINISMO AO PÓS-MODERNISMO: UMA ARTICULAÇÃO}

Atualmente vêm ganhando expressão as pesquisas sobre o mundo feminino, em particular a literatura que contempla as mulheres, as narrativas de autoria feminina. Tal interesse resultou das transformações políticas, econômicas e sociais que se aceleraram, na passagem do século XIX para o século XXI, e deixaram marcas profundas em uma sociedade considerada arcaica e patriarcal, como menciona Nádia Batella Gotlib (2003, p. 21-22) em seu artigo "A literatura feita por mulheres no Brasir":

A condição de subordinação da mulher brasileira, numa sociedade patriarcal de passado colonial, tal como noutros países da América Latina colonizadas por europeus, deixou as sua marcas. Talvez a mais evidente delas seja o silêncio e a de uma ausência, notada tanto no cenário público da vida cultural literária, quanto no registro de nossa literatura. [...] alguns [...] textos referem-se ao isolamento da mulher no meio doméstico, se mulher branca; e os vários ofícios que exercia, se mulher negra. Realçam, em ambos os casos, pelo menos em início do século XIX, o baixo rendimento cultural, já que não tinham acesso à educação que Ihes garantisse a leitura e a escrita.

Considerando tal fragmento, não há mais a necessidade de se reportar aos anos anteriores (digo, de passagem, os anos 60 e 70), quando o apogeu do movimento 
feminista provocou inúmeras discussões, críticas e ataques porque a presença da mulher vinha ganhando espaço e voz em diversas áreas de conhecimento. A constatação de que a mulher assumiu novos papéis sociais, dedicando-se integralmente, por exemplo, à arte da criação literária, enquanto escritora ou leitora, implicou significativas mudanças na estrutura familiar e no campo profissional e intelectual.

A mulher, apesar de estar em um território "nebuloso", "movediço" e talvez "incômodo", transpôs inúmeras barreiras para ingressar e garantir um espaço privilegiado não somente no mercado de trabalho, mas no mundo, com uma voz marcante que ecoa com maior visibilidade nas práticas discursivas de autoria feminina e, sobretudo, nas relações sociais que foram ocultadas durante anos por um caráter androcêntrico.

Convém lembrar que o vocábulo "androcentrismo" nos remete a um "sistema de pensamento centrado nos valores e identidade masculinos, no qual a mulher é vista como um desvio à norma, tomando como referência o masculino" (MACEDO e AMARAL, 2005, p.3)

Diante desta explanação, será introduzido um novo pensamento crítico e inovador que aguça e, ao mesmo tempo, incomoda por meio de uma linguagem que subverte, constrói e desconstrói os valores de dominação, submissão, espoliação, injustiça e discriminação de um ser ainda considerado, por certos olhares, subalterno, secundário, inferior e até como "sexo frágil".

Apesar de continuarem sendo a parte "invisível" da humanidade, as mulheres conseguiram avançar mesmo aos "trancos e barrancos" e lutaram com garras, sem derramar uma gota de sangue, em prol do feminismo revolucionário.

Nesta perspectiva, Heloisa Buarque de Hollanda (1994, p. 7) enfatiza que o pensamento feminista surge como novidade no campo acadêmico e impõe-se como uma tendência teórica inovadora com forte potencial crítico e político. Na verdade, o que se vê é um interesse crescente em relação às teorias feministas e a identificação recorrente de uma "insistente presença da voz feminista" como um dos traços mais salientes da cultura pós-moderna. 
Em consonância com este pensamento, Lucia Zolin (2007, p. 15) afirma que o feminismo é um movimento civil, político e social que luta pela conquista da igualdade, na diferença, entre mulheres e homens. Tem por objetivo promover uma maior visibilidade da mulher como sujeito-produtor de um discurso que se quer novo e dissonante em relação àquele arraigado por toda uma tradição.

Então, essa perspectiva pressupõe que a mulher busca (re)afirmar-se com autonomia no tempo e no espaço, reconhecer-se e autorreconhecer-se em posições diferentes quanto ao grau de complexidade e importância da identidade em uma sociedade em plena evolução, e destaca o modo como a mulher age em prol de uma luta digna pela significação de um lugar privilegiado da/na diferença historiográfica literária.

A respeito ainda desse posicionamento, é interessante observar o estudo da ensaísta norte-americana Elaine Showalter (1985, p. 385) no que concerne à ideia de "uma cultura feminina enquanto uma experiência coletiva no interior da cultura lato sensu e que promoveria uma ligação entre mulheres para além dos limites do tempo e do espaço".

Para complementar o assunto, Edward Said (2000) diz que os estudos feministas promovem um deslocamento radical de perspectiva ao assumirem como ponto de partida de suas análises o direito dos grupos marginalizados de falar e representar-se nos domínios políticos e intelectuais que, normalmente, os excluem, usurpam suas funções de significação e representação e falseiam suas realidades históricas. Mediante tal posicionamento, convém ainda lembrar os demais filósofos franceses pós-estruturalistas como Foucault, Deleuze, Barthes, Derrida e Kristeva que introduziram como assunto inovador (recente) as ideias de marginalidade, alteridade e diferença.

Assim, o panorama da crítica literária feminista pode ser visualizado desde as suas origens até os dias atuais, levando-se em conta as duas tendências, a francesa e a anglo-americana, que passaram a investigar a literatura de autoria feminina por meio de diversos enfoques como o biológico, o linguístico, o psicanalítico e o político-cultural, conforme fora contemplado no capitulo anterior. No entanto, cabe uma reflexão e 
reformulação dessas vertentes, tendo em vista as particularidades, as especificidades e as diversidades de pesquisas existentes nas diversas áreas de conhecimento.

É exatamente neste ponto que o "feminismo" pode estar articulado ao "pósmodernismo", por serem "conceitos" instigantes, relativamente recentes entre nós e ubíquos, possibilitando, assim, a inserção do sujeito-feminino na composição da história, pois este é sujeito na história, que está sujeito à história de sua própria história, à subversão da estrutura arcaica e patriarcal dominante, às reminiscências como rito de passagem de um "passado já passado" vertendo para emancipação futura, à descentralização do tempo/espaço, à fragmentação da narração, ao desdobramento da personagem, à multiplicidade de vozes narrativas, assim como à qualidade estéticoliterária que envolve a tríade proeminente: autor, obra e leitor. Então, faz-se necessário refletir sobre todo o processo de escrita, na medida em que o escritor comprometido e atento a uma dada realidade, particular e ou universal, utiliza as estratégias discursivas necessárias não só para validá-lo, mas para que, a partir daí, possa transcender os limites físicos e culturais do território "tradicional" ao qual pertence e aportar numa outra dimensão, a da criação, da invenção e da imaginação, ao apropriar-se de fatos e personagens já conhecidos como marcas de uma renovação estética, tendo em vista que "cada obra cultural é a visão de um momento, e devemos justapor essa visão às várias revisões que ela gerou" (SAID, 2000, p. 105).

A (re)escritura de Nélida merece destaque ao explorar como referência as histórias de As mil e uma noites como a forma "perfeita" para reverenciar a mulher não só na literatura pós-moderna, mas no mundo, marcando, assim, sua trajetória e autoria na história ao tentar modificar a consciência de um povo.

Por conseguinte, acreditamos que este campo "fértil" que se abre a novas descobertas tende a ser mais uma característica da literatura pós-moderna, concebida por Linda Hutcheon (1991) como metaficção historiográfica ou intertextualidade paródica. Com este conceito, a autora designa obras de ficção que refletem conscientemente sobre a sua condição de ficção, acentuando a figura do autor e o ato de escrever ao expor a ficcionalidade da própria história.

Faz-se necessário, ainda, acrescentar que a metaficção historiográfica preocupase tanto em apresentar fatos e motivos que levaram a eles, quanto em propor uma 
reflexão e/ou uma (re)leitura da história através dos "espaços em branco" deixados pelos discursos oficiais, e inscreve também outros pontos de vista como o da mulher, do empregado, do escravo etc.

A respeito desse assunto, Linda Hutcheon (1991, p. 21-22) tece o seguinte comentário:

Com esse termo, refiro-me àqueles romances famosos e populares que, ao mesmo tempo, são intensamente autorreflexivos e mesmo assim, de maneira paradoxal, também se apropriam de acontecimentos e personagens históricos [...]. Na maior parte dos trabalhos de crítica sobre o pós-modernismo, é a narrativa - seja na literatura, na história ou na teoria - que tem constituído o principal foco de atenção. A metaficção historiográfica incorpora todos esses três domínios, ou seja, sua autoconsciência teórica sobre a história e a ficção como criações humanas (metaficção historiográfica) passa a ser a base para seu repensar e sua reelaboração das formas e dos conteúdos do passado.

Nota-se que a metaficção historiográfica permite uma interpretação de obras do passado de uma forma mais construtiva, ao abordar questionamentos e reflexões tanto para a ficção quanto para a história. A partir daí, Hutcheon estabelece a noção de pósmodernismo como um fenômeno que "usa e abusa, instala e depois subverte, os próprios conceitos que desafia", destacando três características inerentes ao período: "fundamentalmente contraditório, deliberadamente histórico e inevitavelmente político" (HUTCHEON, 1991, p. 19), ao observar como estas características se manifestam. No entanto, para chegar a essa concepção, ela se apoia no conceito pós-moderno de "presença do passado". É interessante lembrar que tal conceito é bem definido em Ensaios de doutrina poética, de T.S. Eliot (1962) no sentido que essa tradição deve ser obtida com muito trabalho, por meio do "sentido histórico" que compreende, além da percepção do passado já passado, a percepção da "presença do passado", tornando o escritor mais consciente de seu lugar no tempo/espaço, ou melhor, de sua contemporaneidade. Por isso, Eliot ressalta que, quando um artista cria uma obra de arte, influencia, simultaneamente, todas as que a precederam. 
Os monumentos existentes formam uma obra ideal, a qual é modificada pela introdução da nova, da verdadeiramente nova, obra de arte. A ordem existente está completa antes da chegada da nova obra; para que ele persista após o acréscimo da novidade, deve a sua totalidade ser alterada, embora ligeiramente e, assim, se reajustam a esta as relações, as proporções, os valores de cada obra de arte: e isto é a concordância entre o velho e o novo. (ELIOT, 1962, p. 24)

Pode-se dizer, então, que há a consciência de um espírito do tempo, em alemão Zeitgeist, ideia que vem à mente na medida em que o passado pode ser alterado pelo presente, tanto quanto o presente é influenciado pelo passado e este repensado no futuro, perfazendo-se assim, uma junção temporal (presente, passado e futuro) ao analisar uma obra de forma mais sistemática e crítica.

Nesta perspectiva, Hutcheon (1991, p. 191) afirma que a paródia seria uma "forma pós-moderna perfeita" porque, ao mesmo tempo em que incorpora, desafia aquilo que parodia, além de questionar a ideia de "origem e/ou originalidade". Então, pode-se dizer que desse posicionamento deriva a natureza da subjetividade pósmoderna, em que a alteração de perspectiva desafia as noções tradicionais de sujeito tanto na literatura quanto na pintura, conforme demonstrado por Anatol Rosenfeld em suas Reflexões sobre o romance moderno (1985). Desta maneira, o pós-modernismo contesta os "pressupostos universalizantes" do humanismo liberal que separam a arte e a vida em compartimentos estanques. Todavia, não os nega, aproveita-os para desmistificar e desfazer as noções de referências, atribuindo novos valores e significados, como aqueles encontrados no romance em análise.

Vale ressaltar que é justamente nesse período (anos 60 e 70) que as "certezas absolutas" caíram por terra, eclodindo com o movimento do feminismo. Portanto, estas ditas "verdades" serviram de base para que muitos teóricos, escritores, críticos e intelectuais repensassem sua condição (posição) e contribuíssem, de forma atuante, para modificar a consciência da sociedade.

Para Hutcheon, essa época forneceu os fundamentos necessários para sua análise: 


\begin{abstract}
A experiência política, social e intelectual dos anos 60 ajudou a permitir que o pós-modernismo fosse considerado como aquilo que Kristeva chama de "escrita-como-experiência-dos limites": os limites da linguagem, da subjetividade e da identidade sexual, bem como - poderíamos também acrescentar - da sistematização e da uniformização. Esse questionamento (e até ampliação) dos limites contribuiu para a "crise da legitimização" que Lyotard e Habermas consideram (cada a um a seu modo) como parte da situação pós-moderna. Indiscutivelmente, ela significou um repensar e um questionamento das bases de nossas maneiras ocidentais de pensar, que costumamos classificar, talvez com demasiada generalização, como humanismo liberal. (HUTCHEON, 1991, p. 25)
\end{abstract}

Trata-se de um período de certezas relativas, "provisórias", e de desafio aos limites das criações humanas, porém, com ênfase na responsabilidade de rever as implicações daquilo que praticamos na nossa cultura e da produção de sentido que nela visualizamos e da qual acreditamos fazer parte como cidadãos.

Nélida Piñon tende a se instituir nesse campo considerado como "pós-moderno", resgatando, por meio da escrita consciente, uma posição que, durante muito tempo, foi negada e negligenciada às mulheres, que passaram a reivindicar a uma sociedade mais justa, humana e igualitária, e conquistaram seus direitos essenciais de cidadã, principalmente, no que concerne à educação, ao combate à violência e, acima de tudo, ao tornar-se mulher. Com isso, a mulher passa a desenvolver competências e habilidades para compreender, interpretar e atuar de forma mais ativa, participativa e crítica num mundo fragmentário, permeado por um olhar sob novas perspectivas: o da diferença em constante vigília ou, ainda, pelo olhar observador e atento à tradição nacional e estrangeira, buscando revalorizar aquilo que é próprio das mulheres, suas raízes, sua identidade, seu modo de pensar, de ser, de estar e de agir no mundo, abrindo-se, assim, para o futuro promissor.

$\mathrm{Na}$ verdade, é dentro deste contexto em estudo e em transformação que pode ser inserida a figura de Nélida Piñon, que foi além dessas indagações e expectativas e brindou os leitores com a questão emergente de gênero, em especial, o feminismo, em consonância com o pós-modernismo configurado por Linda Hutcheon, revelando, assim, um verdadeiro tratado sobre o exercício da criação literária no romance Vozes do deserto, que se destaca não só pelo emprego de grandes metáforas presentes na 
história, mas também pelo poder questionador de fomentar a participação ativa do autor e leitor que são elementos imprescindíveis para a compreensão da obra, conforme arrolados nos estudos desenvolvidos por Jauss e Iser (1979) no campo da Estética da Recepção, ao considerar a literatura um sistema que se define por produção, recepção e comunicação, ou seja, pela tríade proeminente autor, obra e leitor.

A ideia de "feminismo" que se pretendeu esboçar migra para a complexidade e as mudanças dos tempos pós-modernos; ela emergiu quando as mulheres tentaram restabelecer-se e firmar-se como mulheres "diferentes", ousadas, independentes (autônomas) e críticas, capazes de reverter/revolucionar a situação feminina no mundo. Por isso, esse tipo de narrativa pós-moderna funciona como uma confluência de olhares, visões, palavras, um verdadeiro convite à reflexão e não uma mera exposição de ideias prontas e acabadas. Com certeza, como já dizia Hutcheon (1991, p. 19), "usa e abusa" dos recursos narrativos para mostrar que tudo faz parte de um imenso "quebra-cabeça", onde as peças vão se encaixando, de maneira a elucidar que tais experiências, pessoais (particulares) e alheias, tornam-se um material amorfo que cabe a nós, meros leitores, pesquisadores e críticos, moldar de forma mais consciente para criar uma nova realidade.

Nélida Piñon representa a figura feminina do escritor pós-moderno legitimada pela sociedade, pela universidade, pelas inúmeras entrevistas, palestras, conferências, jornadas literárias e constantes prêmios de caráter acadêmico e literário que registram o valor inestimável de suas obras no contexto cultural nacional e internacional.

$E$, para encerrar esta parte de nosso trabalho, enfatizamos que tudo isso só é possível, ou seja, se concretiza graças à literatura que desenvolve em nós a quota da humanidade na medida em que nos torna mais abertos para a sociedade, a natureza, o semelhante e o mundo (CANDIDO, 2000). Portanto, a literatura é uma forma de expressar a visão de mundo de quem escreve, exercendo um papel transformador e dignificante na sociedade. 


\section{3 SOB O JUGO DO PODER, EROTISMO E FEMINISMO}

Pretendemos, neste item, demarcar o espaço da literatura de autoria feminina através da escritora Nélida Piñon, refletindo sobre as vias de acesso que se abriram quando ela retomou uma das personagens mais conhecidas da história da literatura universal chamada Scherezade, no romance Vozes do deserto.

Então, é chegado o momento de mostrar como são construídas as personagens femininas, em especial, Scherezade, desvendando pontos que envolvem a vertente feminina/feminista, bem como de visualizar os conceitos advindos de poder que, junto com a questão do erotismo, contribuíram para promover não somente a libertação das mulheres, mas para estabelecer um vínculo entre elas para além dos limites do tempo e espaço.

Antes de mergulharmos na análise propriamente dita, faz-se necessário salientar que poder, erotismo e feminismo não são mundos distintos um do outro, mas estão entrelaçados entre si e geram polêmicas e controvérsias na sociedade contemporânea, na qual percebemos um conjunto de proibições e tabus, inclusive, de aceitações que têm a finalidade de regular ou controlar o instinto sexual feminino e, consequentemente, a vida alheia. Assim, Nélida torna público a privacidade da mulher no que diz respeito ao corpo e ao sentimento: a intimidade feminina, que deveria ser algo (res)guardado e velado, torna-se assunto de investigação, desde o século XIX para pesquisadores e críticos literários.

Ademais, é um livro que aguça o leitor a ir mais além da escritura e a desvendar os mistérios e enigmas que envolvem a mulher dentro e fora do contexto da literatura brasileira porque promove, com propriedade, a questão da ética, moral, religião e cultura.

Assim, a autora compartilha com o leitor a realidade "nua e crua", ou seja, a visualização de um erotismo direto, sem restrição e preconceito.

De acordo com Nunes (1976), o prazer sexual, que nada tem de obscuro ou de pecaminoso, marca um começo, o início de uma trajetória. E é exatamente esta 
trajetória delineada pelas mãos de Nélida que faz com que as mulheres possam ser vistas, ouvidas e compreendidas sob novos olhares e perspectivas.

Nota-se que a abertura do romance dá-se com a personagem feminina e principal protagonista da história, Scherezade, que demonstra ser corajosa, determinada e consciente ao tentar sobrepor a imaginação à morte, em uma dimensão atemporal, mesclando presente, passado e futuro.

Nesta perspectiva, não há como retratar a personagem acima sem mencionar Anatol Rosenfeld (CANDIDO, 1972, p. 21), quando faz a seguinte colocação:

É a personagem que com mais nitidez torna patente a ficção e, através dela, a camada imaginária se adensa e se cristaliza. [...] E em todas as artes literárias e nas que exprimem, narram ou representam um estado ou estória, a personagem realmente "constitui" a ficção.

Desta maneira, ao refletir melhor sobre a personagem, faz-se necessário salientar ainda as palavras do crítico Antonio Candido (1972), quando ele afirma que "O enredo existe através das personagens; as personagens vivem no enredo. Enredo e personagem exprimem, ligados, os intuitos do romance, a visão da vida que decorre dele, os significados e valores que o animam" (CANDIDO, 1972, p. 53-54).

Pode-se dizer que é "a personagem que representa a possibilidade de adesão afetiva e intelectual do leitor, pelos mecanismos de identificações, projeção, transferência... A personagem vive o enredo e as idéias, os torna vivos" (CANDIDO, 1972 , p. 54). Ademais, o renomado crítico ainda menciona que "o nosso romance tem fome de espaço e uma ânsia topográfica de apalpar todo o país".

Nessa concepção, Nélida vai mais longe e aporta no Oriente Médio, precisamente em Bagdá, tendo em vista que não há fronteiras para o exercício da criação, pois projeta nessa outra geografia uma Scherezade mais guerreira que a da história tradicional.

A força de Scherezade concentra-se em uma das artes mais antigas da literatura: a arte de narrar histórias. No entanto, sua irmã Dinazarda é quem abre o 
caminho para que a primeira narrativa ganhe forma e proporção nos lábios de Scherezade.

Apesar de Dinazarda demonstrar temor pela situação, ela se predispõe a lutar junto a irmã, pois, ao vê-la prostrada na cama, rendida após o coito da primeira noite com o Califa, surpreende-o com a sua presença, exatamente, na hora em que

[...] murmura sons que o Califa mal registra, mas cujas palavras, corajosas, despertam-Ihe a vontade de ouvi-la. Dinazarda aumenta o tom da voz, para só emudecer depois de arrancar do Califa a promessa de ouvir Scherezade. Só então, ajuda a irmã a contar sua primeira história. (PIÑON, 2006, p. 23)

Desde a abertura do romance, observa-se a presença de um narrador em terceira pessoa, heterodiegético, que se reveste de um poder para falar o que the convém sobre a personagem. A partir daí, assume pleno domínio e autoridade de voz, ressaltando a sobrevivência do imaginário sobre o reino da morte.

A personagem parece estar submetida a uma situação sem saída, situação limite de 'confinamento' irreversível para salvar a si mesma, salvar Dinazarda, para salvar Jasmine, para salvar, inclusive, a narrativa das garras do poderoso Califa.

Considerando, ainda, a ideia inicial de "morte" inserida na narrativa como algo inerente do ser humano, Forster (1969, p. 37) salienta que a relação vida e morte é conjetural e move-nos entre duas obscuridades que permanecem abertas para que possamos 'rastrear' as personagens com uso da imaginação, em um tempo cíclico que acena para a eternidade. E se, por acaso, a morte se confirmasse na vida da personagem, seria apenas uma 'passagem' para uma outra dimensão, já que ela não a teme.

Durand (1995, p. 99), ao se referir à imaginação, comenta:

A função da imaginação é, acima de tudo, uma função de 'eufemização', mas não simplesmente ópio negativo, máscara que a consciência ergue diante da hedionda figura da morte, mas pelo contrário, dinamismo 
prospectivo que através de todas as estruturas do projeto imaginário, tenta melhorar a situação do homem no mundo. (DURAND, 1995, p. 99)

A respeito da imaginação, o narrador de Vozes do deserto explica que ela “jamais repousa. É onerosa, promíscua, prisioneira de ilimitados recursos. Com suas combinações inverossímeis e infinitas, ela circula por um território ocupado pelos mestres dos disparates" (PIÑON, 2006, p. 161). Esta observação pode ser válida tanto para Scherezade, que usa e abusa do poder imaginativo, quanto para o Califa que vê a imaginação ganhando forma e corpo a cada dia, pois ele reconhece que é algo, ou melhor, um poder que ele não possui, uma vez que nunca tivera acesso a ele, deixando-o surpreso e boquiaberto com as artimanhas de seu povo.

Seguindo na trilha do poder da imaginação, nota-se que há na personagem feminina, um imaginário inesgotável que vitaliza, dissemina, ressemantiza imagens, criando paradigmas e diretrizes que se fortalecem na estruturação de sua condição de mulher ativa no mundo. Nessa mesma ordem reflexiva, Swain (1994, p. 49) tece a seguinte afirmação:

[...] A posse do controle do imaginário é [...] uma peça essencial do dispositivo do poder e, portanto, os paradigmas criados pelo imaginário são manipulados de forma a dominar e organizar a sociedade de acordo com os interesses dos que detêm o poder.

A personagem Scherezade encarna, no seu estado de espiritualidade, de identidade pessoal e social, grande parte das mulheres que almejam novas perspectivas na sociedade na qual estão inseridas. Todavia, a personagem encontra-se presa à ideologia dominante, nesse caso, representada pelo poder de um ser considerado soberano e prepotente. Uma vez submetida às regras que the foram impostas, deveria obedecer e submeter-se aos papéis convencionais de mulheresposa-amante-objeto, até a chegada da hora do descarte final. 
Segundo Lúcia Zolin, um dos temas principais da obra nelidiana é a condição feminina ou a discriminação social da mulher. Crítica e contestadora, Nélida incomoda a mentalidade patriarcal sem ser panfletária, partidária do sexo feminino ou contaminada por qualquer ideologia radical, porque retrata figuras femininas

[...] inscritas em situações que fazem eclodir essas discussões, seja por meio dos questionamentos das próprias personagens acerca do espaço que lhes é reservado na sociedade, seja por meio de um discurso irônico que, ao retratar a mulher enredada nas relações de gênero, desperta o leitor para o absurdo de certas leis que regulam o comportamento feminino. (ZOLIN, 2003, p. 259)

Desta maneira, Scherezade assume para si o peso de toda uma responsabilidade, sem medir o resultado de todas as consequências que decorrerão deste ato "imprudente", que se impõe mediante tal decisão.

Scherezade, porém, vítima voluntária desta cadeia interminável de jovens assassinadas, fica à espreita. [...] $\bigcirc$ Califa a quer vergada pelo medo, vencida. Procura nas pupilas de Scherezade sinal de angústia pelo seu veredicto, que não capta. [...] O Califa impõe-lhe a tirania dos dias que se seguem. (PIÑON, 2006, p. 72-74-139)

É neste contexto que a personagem "aparentemente" vai sendo construída na narrativa conforme o patriarcalismo dominante, manifestado pela fase feminina da literatura escrita por mulheres, estabelecida por Elaine Showalter (1985). Portanto, com sua Scherezade, Nélida rompe com esse "modelo" vigente da fase feminista ao buscar a sua independência no mundo, libertando-se das amarras e dos papéis arquetípicos, tradicionais ou ainda arcaicos. Com certeza, a última fase "fêmea", determinada pela ensaísta norte-americana e retomada por Nélida, enfatiza a autodescoberta da mulher e a busca da sua identidade, sob uma perspectiva mais ampla.

O espaço que a personagem percorre desde o início é descrito como "câmara da morte", lugar frio, obscuro, de penumbras e impregnado de poder e violência, que se 
confirma e prolifera nos vocábulos "morte", "extermínio", "cadafalso", "mortiços" entre outros que seguem nos capítulos subsequentes do romance.

O personagem Califa, desde as suas primeiras "aparições", é apresentado como um ser "Poderoso", um "Soberano" que tem e detém a seu favor o poder. Poder este de ordenar a morte de seus inimigos, assim como de suas futuras esposas-amantes e vice-versa.

[...] Não acredita que o poder do mundo representado pelo Califa, a quem o pai serve, decrete por meio de sua morte o extermínio de sua imaginação. [...] Não suporta ver o triunfo do mal que se estampa no rosto do Califa. [...] A qualquer instante, sujeitas ao arbítrio do soberano, as filhas seriam levadas ao ara do sacrifício sem tempo de expressar ele a sua revolta. (PIÑON, 2006, p. 7-11)

[...] Havendo seu comportamento se transformado a partir da traição da Sultana, que the infligira severa dor, tudo se podia esperar dele, inclusive a aplicação indiscriminada de pena de morte contra jovens inocentes. [...] Scherezade, porém, vítima voluntária desta cadeia interminável de jovens assassinadas. (PIÑON, 2006, p. 62-72)

Este "poder" também é evidenciado e reforçado pelo tesouro, pelas vestimentas e pelos luxuosos acessórios (jóias), representando a monarquia/nobreza.

[...] os suntuosos adereços do Califa, em meio aos quais se destaca seu turbante branco. Assim como as jóias que integram o tesouro abássida, exibidas por ele sem constrangimento, e que reverberam à luz do sol. [...] Seu traje, imponente, traz na parte frontal um bordado de inspiração estrangeira, cujos detalhes meticulosos registram a evolução da caça ao cervo. (PIÑON, 2006, p. 10-15)

Entretanto, convém enfatizar que o vocábulo "poder" nos remete às palavras de Michel Foucault: "[...] Poder... esta coisa tão enigmática ao mesmo tempo visível e invisível, presente e oculta, investida em toda parte. Onde há poder, ele se exerce... 
não se sabe ao certo quem o detém; mas se sabe quem não o possui" (FOUCAULT, 2003, p. 75).

Por outro lado, é interessante lembrar a observação de Guacira Lopes Louro (1997), que constata que o poder não deve ser percebido apenas como coercivo e negativo, mas também como algo produtivo e positivo:

[...] O poder não apenas nega, impede, coíbe, mas também 'faz', produz, incita. Chamando a atenção para as minúcias, para os detalhes, para táticas ou técnicas aparentemente banais, Foucault nos faz observar que o poder produz sujeitos, fabrica corpos dóceis, induz comportamentos, 'aumenta a utilidade econômica' e 'diminui a força política' dos indivíduos [...]. (LOURO, 1997, p. 40)

Nesse caso, sabe-se que o poder se exerce "sim" e que se encontra, até certo ponto, nas mãos do Califa e em um espaço onde para a mulher era proibido movimentar-se e sobressair-se com êxito. No entanto, é por intermédio do poder da palavra que a personagem Scherezade sonha libertar o reino do maldito decreto que aterroriza toda uma classe marginalizada, desprezada e desfavorecida. Desta maneira, ela consegue falar dentro do mundo masculino sobre seu mundo, abrindo reflexões e debates consigo mesma e até com o leitor sobre a situação feminina e sua adaptação no espaço público. Isto denota que o feminismo se revela como [...] a procura da identidade feminina que substitui a da igualdade com os homens. É, sobretudo, o desejo de dar voz a essa identidade, de fazer existir o Feminino como presença na cultura, que se insinua na literatura (OLIVEIRA, 1999, p. 43).

É válido observar que o poder do Califa se concentra apenas em ações de repressão, violência e exploração do corpo da personagem, conforme se pode comprovar nas seguintes passagens:

[...] em breve o Califa viria cobrar seu corpo. [...] Confrontada com aquele corpo que se esvaziara para o cumprimento do seu dever, Dinazarda rejeita a visão do Califa brandir o membro como instrumento de conquista.

(PIÑON, 2006, p. 12-13) 
[...] Embora ele encarne o califado de Bagdá, ela não controla sua repulsa pelo homem na iminência de invadir a vulva da irmã (Scherezade) com o ar de dono... cede ao Califa partes do seu corpo... a noção do corpo pertence somente a ele e mais ninguém. (PIÑON, 2006, p. 14)

Assim, a virilidade masculina torna-se mais um instrumento, uma espécie de conquista nas mãos do Sultão, que tem o poder de usar e manipular o corpo alheio como objeto, sem demonstrar nenhuma forma de afeto, mas somente de brutalidade e violência.

[...] Scherezade retornou ao Califa "de seu devaneio" justo no instante em que ele, arrancando-lhe a peça íntima, expunha, à luz da lamparina, seu púbis escuro, em cuja fenda cerrada introduziu, de um só golpe, o membro autoritário. (PIÑON, 2006, p. 20)

Nota-se que para a personagem, a vida de represália obriga-a a reprimir "momentaneamente" seus instintos de liberdade e de prazer e, consequentemente, a conviver com os dissabores, frustrações e sofrimentos que são próprios do ser humano.

$\mathrm{Na}$ verdade, percebe-se que há resistência por parte da personagem, porém o poder se exerce em uma manifestação de obediência que também prolifera nas relações entre mulheres.

A partir do momento em que o indivíduo está em uma situação de não fazer aquilo que deseja, utiliza as relações de poder. Muitas vezes, a resistência pode sobressair-se como uma força superior desse processo, obrigando a mudar as relações de poder e repensar essa questão como algo positivo que faz parte do processo de criação, recriação, podendo transformar a situação e o próprio sujeito.

Nota-se que as cenas de sexo são visualizadas pelo leitor de forma explícita, ou seja, são "escancaradas" e o leitor pode, assim, estabelecer o entrelaçamento entre a questão do poder, as ocorrências eróticas que primam pela realização do próprio ato em si e a violência, reforçando o caráter de crueldade, hostilidade e de conquista, quando se verificam a submissão e a posse da mulher pelo homem, sem qualquer tipo de sentimento. 
[...] membro empedrado do Califa forçando-lhe a entrada do sexo, sem levar em consideração que tinha ainda as paredes secas. [...] Forçada, porém, a ceder ao jogo sexual do soberano, Scherezade aproveita-se da alcova para imprimir erotismo às suas tramas... para isto domestica sua dor, torna-a inexpressiva. (PIÑON, 2006, p. 17-42)

[...] Scherezade ressente-se de que, forçados à intimidade imposta pelos exíguos aposentos, Ihes falte cerimônia. Aflita, ela cerra os olhos mesmo à luz do dia [...] Uma promiscuidade [...] Prestes a copular, ele livra-se apenas de partes dos trajes, só deixando a genitália escura à mostra. (PIÑON, 2006, p 103)

Ainda percebe-se que a questão do sexo aparece como um ato de sacrifício, pois, quando o ato sexual não é sinônimo de doação, quando não há cumplicidade, "não se pode, em rigor, falar de união, mas sim de dois indivíduos dominados pela violência, associados pelos reflexos ordenados da conexão sexual, que partilham um estado de crise em que um e outro estão fora de si" (BATAILLE, 1980, p. 34). Assim, o Califa não compartilha nem com Scherezade nem com nenhuma outra mulher o prazer almejado. Ao apossar-se do corpo feminino com o ar de dono, explora suas entranhas com o ímpeto de sacrificador, e um e outro, no decurso da consumação, perdem-se na continuidade estabelecida por um primeiro ato de destruição (BATAILLE, 1980, p. 36). Desta maneira, constata-se que o amor carnal não foi o início de uma aprendizagem, porque não houve envolvimento mais profundo, apenas o deflorar, o devorar de vulvas virgens.

Nesta concepção, ao refletir sobre o ato propriamente dito, nota-se que quando ocorre uma entrega de corpos ardentes entre o homem e a mulher, estes celebram juntos e de forma integral a cerimônia dionísica, aceitando sem oposição a força erótica da existência nesse processo de explosão e renovação de Eros. Então, há uma projeção de uma força recíproca que se revigora, projetando luz e vida.

Posteriormente, na força imagética dessa "exposição" atualiza-se o próprio prazer, prazer de saber, de exibir as fantasias escondidas, de descobrir, de fascinar e de dizer as "verdades", as revelações dos impulsos, os desejos secretos e até mesmo uma curiosidade capaz de vincular ou, até mesmo, acumular conhecimentos sobre o 
assunto em questão, embora ainda seja controlado nesse deserto, um espaço "infértil" onde o prazer erótico é corroído por uma ideologia dominante patriarcal.

Nesta perspectiva, pode-se inferir que Nélida Piñon, assim como outras escritoras do século $X X$, descreve de que maneira as experiências sexuais são vividas por uma mulher, denotando a exteriorização de uma sexualidade em chamas, num domínio que, até então, fora reservado aos homens.

Desta forma, a representação erótica vai afirmando-se intensamente na narrativa, a partir do conflito entre a instância repressiva/ opressiva e a necessidade de expansão do desejo de autonomia, emancipação e liberdade.

Nesse sentido, evidenciam-se inúmeras passagens em que se mostra como Scherezade tira proveito da alcova para fixar erotismo à sua urdidura, fazendo uso de seus sentimentos e desejos para "emprestar a príncipes e plebeus, escolhidos a esmo, as palavras apaixonadas que intensificam a vulva de Zoneida e o falo de Simbad" (PIÑON, 2006, p. 42).

Apesar de ser exímia narradora e contadora de histórias, a personagem Scherezade tem como objetivo "perturbar o Califa por meio de emoções contraditórias, em deslocá-lo do sexo para as palavras, impingir-lhe a lenta agonia advinda da sua manha narrativa" (PIÑON, 2006, p. 43).

Segundo o escritor e crítico Otávio Paz (1994, p. 16), o erotismo pode ser abordado como uma metáfora da sexualidade; é exclusivamente humano: é sexualidade socializada e transfigurada pela imaginação e vontade dos homens. $O$ erotismo é invenção, variação incessante; o sexo é sempre o mesmo. Todavia, sexo e erotismo fazem parte do mesmo fenômeno, ou seja, são manifestações. A intenção não é estabelecer um aprofundamento desse tema complexo. Embora o erotismo faça parte do mesmo fenômeno do sexo, o intuito é que possa ser visto como uma manifestação natural da vida, conforme está expresso no romance de Nélida.

Neste âmbito, Bataille (1987) salienta que o erotismo reside, justamente, em uma forma particular de atividade sexual, só se manifestando quando o sexo ultrapassa a função meramente reprodutiva e se estabelece como busca de autoconhecimento, de completude. Ademais, o escritor revela que há três tipos de erotismo: o erotismo dos corpos, o dos corações e, por fim, o sagrado, em que se substitui a descontinuidade por 
uma continuidade conforme menciona: "Falarei dessas três formas a fim de deixar bem claro que nelas o que está sempre em questão é substituir o isolamento do ser, a sua descontinuidade, por um sentimento de continuidade profunda" (BATAILLE, 1987, p. 15).

Desta maneira, Scherezade ou, ainda, essa representação de mulher tenta ganhar um pouco de tempo e tece novas informações acerca da intimidade do ser humano, referindo-se a si mesma, a outros seres e personagens já conhecidos como Ali-Babá e Simbad, o Marujo, para promover um efeito de "remissão" e, consequentemente, salvaguardar tanto a alma feminina quanto a masculina.

Nota-se que a intimidade pode ser evidenciada em vários episódios da narrativa, em especial, nos momentos em que o Califa desnuda a princesa com certo toque de voracidade ao arrancar suas peças íntimas, denotando poder e violência.

Em relação a essa visão (da intimidade) e a partir do desnudamento, esses corpos se fundem, se dissolvem na continuidade do sexo em que, mesmo sem amor, há a manifestação da violência. A esse respeito, Bataille (1987) reforça:

Toda a atividade do erotismo tem por fim atingir o ser no mais íntimo, no ponto onde ficamos sem forças. [...] No movimento da dissolução dos seres, o parceiro masculino tem princípio ativo; a parte feminina é passiva. É essencialmente, a parte feminina que é desagregada como ser constituído. Mas, para um parceiro masculino, a dissolução da parte passiva só tem um sentido: ela prepara uma fusão na qual se misturam dois seres que, no fim, chegam juntos ao mesmo ponto de dissolução. Toda realização erótica tem por princípio uma destruição do ser fechado que, no estado normal, é um parceiro do jogo. (BATAILLE, 1987, p. 16-17)

Diante do exposto e em se tratando de observar uma relação hierarquizada entre os gêneros e fortemente enraizada na sociedade, torna-se difícil para as mulheres conscientes não olhar o mundo segundo os binarismos criados a partir do masculino/feminino, todavia, voltados para uma nova percepção da realidade que está instaurada na narrativa.

Esse posicionamento nos remete à análise de Pierre Bourdieu expressa em $A$ dominação masculina (1999, p. 50), em que o princípio de inferioridade e exclusão da 
mulher é ratificado por um sistema mítico-ritual que rege a divisão do mundo. Trata-se de uma dissimetria fundamental, a do sujeito/objeto, agente/instrumento, que está presente em todas as relações de produção e de reprodução do capital simbólico, com a função de perpetuar o poder dos homens.

Partindo desse pressuposto, às mulheres não cabe mais a imposição de disciplina relativa a mente/corpo como resultado de submissão, opressão, repressão e até de violência. Prova maior é a valorização da personagem Scherezade que, apesar de perambular por uma zona de perigo, cumpre seu papel de heroína e guerreira destemida para transformar-se na mulher sagaz e dona do próprio destino. Desse modo, passa a vislumbrar as minúcias da vida cotidiana, ao observar "o pássaro que pousara nos jardins... A imagem do pássaro realça a liberdade que ela perdera" (PIÑON, 2006, p. 191).

De acordo com o Dicionário de símbolos de Cirlot (1984, p. 446), o pássaro é, em si, um símbolo fálico, mas dotado de poder ascendente, sublimação e espiritualização, ao representar os estados superiores do ser. Então, ao associá-lo à figura de Scherezade, notamos que é como se sua alma estivesse configurada dentro do pássaro, voasse do seu corpo e aportasse em uma outra dimensão inebriada pela liberdade de desfrutar um novo dia, cantarolando e falando como uma mensageira da palavra. Daí, ao pássaro pode ser atribuído o significado de mensageiro, uma divindade criadora.

Assim, à parte, pode-se dizer que a imagem do pássaro vem aludida à da natureza, ou melhor, ao jardim, uma vez que a personagem sente-se "presa" neste ambiente em que floresciam sentimentos na iminência de desembocar em um desfecho trágico ou não. A partir daí, Scherezade se entrega a sua fantasia habitual e o jardim se revela como um símbolo do poder da mulher e, em particular, do seu poder sobre a natureza domesticada por oposição à natureza selvagem. Desse modo, o jardim representa um sonho do mundo que transporta para fora do mundo, como a expressão de um desejo puro de qualquer ansiedade. É ele o sítio do crescimento, do cultivo de fenômenos vitais e interiores (CHEVALIER \& GHEERBRANT, 2002).

Para Cirlot (1984, p. 320), o jardim é o âmbito em que a natureza aparece submetida, ordenada, selecionada, cercada, podendo corresponder ao simbolismo da 
paisagem. Desta maneira, por ser um atributo feminino desde os séculos XVI e XVII, constitui um símbolo da consciência diante da inconsciência.

Cabe lembrar que a ideia da consciência de Scherezade está associada ao símbolo da janela, pois sempre, quando está agoniada ou desesperada, ela procura uma "via" de abertura ou, ainda, um rito de passagem para a eternidade, na medida em que a personagem penetra no âmago de sua consciência para refletir e adicionar histórias ao seu repertório, tendo a possibilidade de aproximá-la e distanciá-la da situação e, consequentemente, de permitir a transgressão da realidade da qual faz parte. Portanto, a janela simboliza a receptividade e possibilita ver a mudança através da diferença (CHEVALIER \& GHEERBRANT, 2002).

Outro ícone que merece ser destacado é a fonte, pois é o local onde a personagem busca energia para reviver o passado, revigorar-se e inspirar-se no futuro.

[...] À beira da fonte, cujo jorro de água ia-lhe salpicando o rosto, Scherezade, ao lado de Fátima, revivia o mercado de Bagdá, cenário real das histórias que fabulava... Uma turbulência, graças à qual ia tocando o coração da arte de inventar. (PIÑON, 2006, p. 248)

De acordo com Cirlot $(1984,261)$, a fonte, água que brota, apesar de ocupar o lugar central, simboliza a força vital do ser humano e de todas as substancias, cujas águas podem assimilar-se à "bebida da imortalidade". Jung liga a fonte a uma imagem da anima como origem da vida interior e da energia espiritual (CIRLOT, 1984, p. 262). Daí justificar-se-á a presença da personagem na fonte, pois, até na Bíblia, nota-se a vasta utilização desse líquido transparente como um dos elementos purificadores. Nesse sentido, a água se torna o símbolo da vida espiritual como exemplificado em João, capítulo 4, versículo 4: "Aquele que beber da água que eu vou dar, esse nunca mais terá sede. E a água que eu lhe darei, vai se tornar dentro dele uma fonte de água que jorra para a vida eterna" (BIBLIA SAGRADA, 1990).

Podemos associar também a imagem da ave que renasce das cinzas, a Fênix, à Scherezade, na medida em que lhe é permitido sobreviver a cada instante e a vencer cada uma das mortes parciais chamadas sonho, mudança ou transformação. 
É preciso acrescentar que, no ocidente cristão, essa ave mítica significa o triunfo da vida eterna sobre a morte (CIRLOT, 1984, p. 252), ou seja, é o próprio reviver/ renascer desta nova mulher que desponta no horizonte.

Assim, alçando voos ainda mais longos e enredados em poderes supranormais da alma humana, atribuímos à Scherezade a imagem das fadas, no sentido de que, mesmo sem a "varinha mágica de condão", ela tem o poder de fazer surgir personagens, palácios, objetos maravilhosos etc. No sentido tradicional, as fadas são consideradas fiandeiras como as parcas. Além disso, pode-se atribuir a elas o símbolo da sabedoria.

Por outro lado, faz-se necessário lembrar, ainda que, o suplício pela vida é uma constante manifestada pela personagem Scherezade, que tem a função de fazer brilhar a verdade, que está "oculta" aos olhos de todos: revela a mulher que sofre, sente e chora as atrocidades da vida cotidiana.

Para Foucault (1987, p. 30), "o suplício repousa na arte quantitativa do sofrimento". Essa ideia de suplício vinculada ao sofrimento nos permite correlacionar o tipo de submissão, repressão, opressão e a intensidade da violência mantida pelo Califa sobre a personagem Scherezade. Desta maneira, torna-se visível para o leitor a situação desta mulher que, aparentemente, não consegue se livrar desse tormento que marca a sua vida, gerando, assim, uma profunda cicatriz no seu imaginário pela barbárie e crueldade sofrida durante todos esses anos de existência e convivência ao lado de um ser que jamais a mereceu.

Diante do exposto, percebe-se que a trajetória de Scherezade é árdua, uma vez que ela é mantida como "refém", isto é, "prisioneira" numa espécie de cativeiro, ou melhor, de uma prisão.

[...] Resguardada e ciosa, ela se ressente do cativeiro em que vive no palácio. Razão de sua desabrida imaginação semear ilusões, mentiras. Mas é da prisão também que ela semeia falsas esperanças. Dando a ele motivo diário para ameaçá-la com a morte. (PIÑON, 2006, p. 60) 
[...] Os aposentos oferecem a Scherezade a única geografia ao seu alcance. Como prisioneira do Califa. [...] A irmã aceita o cativeiro como querendo esquecer as formas do mundo para descrevê-la a seu jeito. [...] Promete um dia livrá-la daquela prisão. (PIÑON, 2006, p. 144-148-263)

Nesse sentido, a prisão atua como uma "força superior" capaz de reprimir, punir, dominar e até redimir uma pessoa, nesse caso, a personagem Scherezade. É uma das forma mais arcaicas de manifestar o poder do tirano sobre a figura feminina "mulher", com os mais íntimos e escancarados detalhes pela supressão da sua liberdade.

No que concerne a essa observação acerca da prisão, faz-se necessário ressaltar o que Michel Foucault afirma a este respeito:

[...] Prender alguém, mantê-lo na prisão, privá-lo de sua liberdade, impedilo de sair etc... é a manifestação de poder mais delirante que se possa imaginar... [...] A prisão é o único lugar onde o poder pode se manifestar em estado puro em suas dimensões mais excessivas e se justificar como poder moral. (FOUCAULT, 2003, p. 72-73)

É válido ressaltar que, nesse ambiente sórdido em que Scherezade se encontra, origina-se um tipo de 'isolamento' em que transparecem a solidão e a angústia asseguradas pelo poder que se exerce sobre ela. Essa espécie de isolamento absoluto suscita uma reflexão da personagem com sua própria consciência e com aquilo que pode iluminá-la de dentro, pois o referido autor ainda salienta que:

Sozinho [o indivíduo] em sua cela está entregue a si mesmo; no silêncio de suas paixões e do mundo que o cerca, ele desce à sua consciência, interroga-a e sente despertar em si o sentimento moral que nunca perece inteiramente no coração do ser humano. (FOUCAULT, 1987, p. 201)

Então, como se não bastassem as inúmeras emoções de cadafalso ou, ainda, desse sepulcro provisório, surge a figura estarrecedora do carrasco para reafirmar a questão do poder e aterrorizar ainda mais o espírito humano. Dessa forma, o processo 
de punição, pouco a pouco, vai sendo instaurado como uma consistência negativa nas mãos deste ser cruel para dar um "fecho" à vida apenas pelo prazer de punir e cumprir ordens.

[...] O cadafalso, de construção esmerada, fora erguido com a finalidade única de servir às jovens esposas do Califa, condenadas ao amanhecer. Por ordem do soberano... a execução das esposas. Uma função para qual os carrascos, designados para este fim, mantinham-se em permanente vigília. [...] O pavor da morte causa-lhe calafrios. (PIÑON, 2006, p. 11-68)

Neste âmbito, pode-se dizer que somente quem passa por situação semelhante, nesse caso, as vítimas (Scherezade, Dinazarda e Jasmine), consegue descrever os tipos de pressões e torturas sofridas neste local "aparentemente" de recuperação, salvação, ou até mesmo, perdição.

Para Gilles Deleuze (2009, p.19), um dos maiores filósofos da contemporaneidade, os carrascos necessariamente empregam a linguagem hipócrita da ordem e do poder estabelecidos:

[...] Como regra geral, o carrasco não emprega a linguagem da violência que ele exerce em nome de um poder estabelecido, emprega a do poder, que aparentemente o desculpa, o justifica e fundamenta sua posição. $O$ violento é levado a se calar e se adapta à trapaça. (DELEUZE, 2009, p.19)

Vale mencionar que é nesse ambiente sórdido que ocorrem as "coisas à revelia" e sem máscaras, podendo germinar entre outras coisas a "morte" consciente e inconsciente, física e espiritual, reduzindo a vida a um fio tênue e, muitas vezes, quase sem volta.

Apesar de todas essas formas de poder manifestadas pelo Califa, ele parece ser repudiado pelo narrador, narrador que se desdobra em personagem, personagem que é personagem da própria história e que dá voz a outros personagens, constatando-se uma polifonia de vozes narrativas que também serão retomadas no quarto capítulo. 
Por isso, no decorrer da narrativa, nota-se, ainda, a preocupação tanto por parte do escritor quanto do leitor, de investigar e refletir sobre o processo de criação exposto na ficcionalidade da própria obra. Desta maneira, o leitor é convidado a assumir sua posição na narrativa e desvendar uma série de dilemas que envolvem não somente o sujeito feminino representado por Scherezade, mas a mulher em si, o papel do escritor e a obra de uma forma mais crítica.

Assim, a atenção do leitor é despertada desde a abertura do romance, quando a personagem feminina Scherezade enfrenta e desafia com coragem a tirania (prepotência) e a violência do poderoso Califa com a ousadia da imaginação, representada neste contexto, pela palavra que se sobrepõe ao poder. "Scherezade não teme a morte. Não acredita que o poder do mundo, representado pelo Califa, a quem o pai serve, decrete por meio de sua morte o extermínio da sua imaginação" (PIÑON, 2006, p. 7).

A partir daí, configura-se uma verdadeira inversão de poder, de papéis e valores, pois a palavra narrada é uma maneira de conscientizar, enfrentar e lutar contra todas as mazelas que afetam a figura feminina, ou melhor, a mulher numa sociedade ainda considerada arcaica e patriarcal.

Quanto a esta inversão, nota-se que este "poder" centra-se nos lábios de Scherezade, personagem audaciosa, astuta, sedutora e confiante.

[...] Scherezade seduz a imaginação do soberano. [...] com desenvoltura o Califa troca os prazeres da cópula pelas histórias, pois ela exerce com vigor a emérita arte da sedução. [...] Confia que sua força narrativa assombre o Califa, suscite nele encanto, dobre-lhe o espírito. (PIÑON, 2006, p. 185-216-263)

O poder está representado por essa mulher que engendra nas "veias" o dom da palavra, da imaginação, da invenção, da criação e da fabulação. É uma guardiã da palavra, pois tem o poder de proferi-las ao contar e narrar, fiar e desfiar histórias ininterruptas para manter-se viva e garantir a sobrevivência das demais jovens do reino. 
[...] E de sua vocação de inventar e de viver muitas vidas ao mesmo tempo. Scherezade fora a primeira a interromper a sequência das execuções. [...] Scherezade sabe-se instrumento da sua raça. Deus Ihe concedera a colheita das palavras, que são o seu trigo. (PIÑON, 2006, p. 171)

Scherezade aprende a sobreviver. As regras da vida não estão escritas. Cabe-Ihe inventá-las a cada aurora. [...] Confia em sua arte, que se tem mostrado superior aos folguedos da carne. Sempre contara histórias de forma ininterrupta. (PIÑON, 2006, p. 255)

No decorrer da narrativa, Scherezade assume inúmeros papéis como o de irmã, filha, princesa, esposa, personagem, contadora de histórias, narradora, mestra e, acima de tudo, mulher.

[...] No dia previsto, Scherezade aprontou-se, indiferente ao sofrimento do pai. A filha deixou a casa do Vizir sem olhar para trás. [...] Dinazarda anima a irmã a resistir ao Califa, que logo virá dar posse ao seu corpo. (PIÑON, 2006, p. 9-13)

[...] $\mathrm{Na}$ condição de princesa, Scherezade é uma ardorosa filha do deserto, herdeira da medina. [...] No papel de narradora, não lhe é alheio o destino dos que empunham armas e matam. [...] mas por que haveria ele de criticar sua mestra na arte das peripécias? [...] Na qualidade de singela contadora de histórias, estava, isto sim, a serviço da adversidade e do inusitado. (PIÑON, 2006, 69-290-295)

É válido observar que essa visão de mulher total que se desdobra em múltiplas imagens, reforça uma perspectiva revolucionária e de liderança feminina futura, ao exercer várias posições na sociedade. Nesse sentido, Nélida não hesita em projetar as diferentes classes sociais na narrativa, envolvendo desde a aparição de uma simples escrava como representação de uma classe marginalizada até a incorporação de uma outra estirpe - a princesa Scherezade. Aliás, permite evidenciar uma mulher que possui uma espécie de "vocação" para engendrar estratégias e artimanhas necessárias para 
manter o sexo oposto [o Califa] sob seu poder narrativo, explorando os mais variados temas como a questão feminina, o amor, o sexo, a traição, o ódio, a inveja, a morte etc.

Com certeza, esse procedimento possibilitou que a personagem Scherezade neutralizasse as ações, atitudes e comportamentos nefastos deste homem que promulgou o extermínio de todas as mulheres.

[...] Para isto orquestrando frases, dando-Ihes suntuosidade, captando as peripécias que hipnotizavam o Califa. [...] Scherezade atiça a imaginação do Califa jamais o seu desejo. [...] o brilho está nas palavras com que conta as histórias. (PIÑON, 2006, p. 75-105)

[...] Um saber único, com o qual imprime rumo à história... Aquela contadora sabe como ninguém brandir os distúrbios e os devaneios que acossam seus personagens diante do rosto imutável do Califa, fazendoIhe ver que também ele corre o risco de perecer com a morte de cada ser que ela inventa. (PIÑON, 2006, p. 97)

A personagem masculina do Califa é apresentada ao leitor por um viés que não Ihe é muito favorável, ou seja, "negativo" e "ruim", pois é visto como "tirano", "cruel", "repugnante", "impaciente", "insatisfeito", "prepotente", "frio", "calculista", "macho desajeitado" e "indolente", "obsessivo" e até "desprezível". Com certeza, essa proliferação de adjetivos contribui para a sua derrocada do pedestal, destituindo-o de toda e qualquer forma de poder. Contrariamente, Scherezade recebe todas as adjetivações que a enaltecem e a idolatram como um ser que detém e se apodera de um conhecimento inimaginável e inestimável que nem as marcas do tempo podem apagar.

[...] impressionava mestres e ouvintes... Scherezade cobrava dos mestres as chaves com as quais abrir as portas da percepção e da sabedoria. Nada Ihe satisfazia a ambição intelectual, para a perplexidade dos professores. (PIÑON, 2006, p. 112) 
[...] Um saber único, com o qual imprime rumo à história. [...] Uma edificação verbal mais poderosa que qualquer mesquita ou palácio erigidos com pedra, cal e suor. O que Scherezade semeara nos aposentos, através dele, nunca se apagaria. (PIÑON, 2006, 97-351)

Scherezade tem a seu favor uma "teoria" que foi conquistada ao longo dos anos por meio de educação refinada, a imaginação herdada da mãe que the propicia a "arte de narrar e fabular", os recursos da memória, as lendas por meio de culturas nômades que atravessaram o deserto, as tundras, o espaço geográfico e a mística.

Vale ressaltar que a voz de Scherezade ecoa como um "alucinógeno", uma espécie de "antídoto" capaz de afugentar o temor, dissipar a dor e banir todo o sofrimento que corrói e devasta a alma. Além disso, provoca "prazer" imediato e, ao mesmo tempo, suscita uma transformação consciente, ao resgatar valores que possam estar "perdidos" para a humanidade.

[...] Deus the concedera a colheitas das palavras, que são o seu trigo, pois sabe como ninguém brandir os distúrbios e os devaneios que hipnotizavam o Califa. [...] a jovem lhe reserva às noites para atiçar o fogo da imaginação. [...] Scherezade fora a primeira a interromper a sequência das execuções. [...] Cabe-Ihe inventá-las a cada aurora Sempre contara histórias de forma ininterrupta. (PIÑON, 2006, p. 171-216-236-255)

Cabe lembrar que, nas palavras de Scherezade, se inscreve o poder de transgredir os limites da imaginação e fixar-se nas minúcias da vida cotidiana, evidenciando uma constante preocupação e similaridade com o ofício do escritor, assim como do leitor na narrativa. Ambos são, conforme já observamos, imprescindíveis e foram amplamente abordados pela estética da recepção, e visam a uma reflexão mais acurada sobre o "processo de criação" e compreensão da obra e do mundo, conforme deixa evidente o narrador nas passagens que seguem:

[...] Aprendera que para seduzir o ouvinte convinha obedecer a pausas respiratórias, dar às palavras dosagem do pecado. [...] Preocupa-se agora conceder prazer aos ouvintes, adotar ritmo compatível com o volume das emoções concentrada em cada episódio. (PIÑON, 2006, p. 97-257) 
Essa preocupação desemboca nas práticas discursivas feministas, configurando um tom, um ritmo, uma respiração e uma dicção própria ao almejar mudanças significativas na situação feminina. Ademais, pode-se dizer que é através da linguagem que a personagem assumiu todo o poder da situação, propiciando a imposição de uma outra realidade para si e para o outro, num processo revolucionário para reafirmar-se no tempo e no espaço enquanto mulher e com uma voz que ecoa nos lugares mais longínguos, visando ao seu reconhecimento, autonomia e liberdade.

[...] Como resultado de seu engenho, o soberano ia-se descobrindo detentor da habilidade de reproduzir mulheres com autonomia. A ponto de este procedimento ficcional dar-lhe, e pela primeira vez, entrada ao mundo de Scherezade. (PIÑON, 2006, p. 59)

[...] Assim a conjugação das palavras da jovem [...] arranca o Califa das amarras da realidade. [...] Modelaram nele praticamente um outro ser [...] [...] Comove-se com a jovem empenhada em apreender o mundo com suas palavras. [...] $O$ que Scherezade semeara nos aposentos através dele nunca se apagaria. (PIÑON, 2006, p. 235-287-333-351)

A partir daí, nota-se uma maior valorização da figura feminina e da força motriz de uma linguagem consciente que almeja novos rumos, viabilizando a transgressão da mulher na cultura contemporânea, ao dar visibilidade a sua voz e identidade ao próprio ser, visto que fora projetada no reino das palavras, ganhando um novo sentido à sua existência, bem como à vida.

Portanto, Scherezade é a afirmação do protótipo feminino, pois ela não pode ser desviada de seu destino original de ser uma via de acesso ao território feminino para conquista da liberdade e autonomia. Assim, ela utiliza o seu lado fecundo e fértil para engendrar conhecimento, luz e sabedoria, pois o discurso sobre a mulher contribui para a construção da própria mulher no tempo e no espaço. 


\subsection{VISÕES PROJETIVAS DA CULTURA CONTEMPORÂNEA: A REPRESENTAÇÂO DE SCHEREZADE NO ARQUÉTIPO DA GRANDE MÃE E PENÉLOPE}

Apesar de a mulher continuar sendo a parte invisível da humanidade, abrimos este item com o "Princípio Ativo Feminino", personificado pela "Divindade Suprema de a Grande Mãe" para abrilhantar a representação de Scherezade na cultura contemporânea.

A Grande Mãe representa a totalidade da criação e a unidade da vida, pois ela existe e reside em todos os seres e em todo o universo. Desta maneira, seus múltiplos aspectos e manifestações recriam o eterno ciclo de nascimento, crescimento, florescimento, decadência, morte e renascimento no perpétuo movimento da vida.

Esta premissa nos remete aos "arquétipos", no sentido de modelos construídos durante milênios para projetar essa imagem em nosso insconsciente, tornando-a comum a toda a humanidade.

Segundo o mitólogo Erich Neumann, em sua obra $A$ Grande Mãe (2006), a definição de arquétipo pode ser compreendida como "[...] um fenômeno nuclear que transcende a consciência, e cuja presença eterna é não visível” (NEUMANN, 2006, p. 21), ou ainda, [...] um modelo, primordial e eterno, de impulsos ou comportamentos humanos, instintivos, que se formaram na origem dos tempos e permanecem latentes no espírito humano. (NEUMANN, 2006, p. 22)

Carl Gustav Jung (1875-1961) afirma que

[...] Arquétipo é um motivo mitológico (mítico) e que, como conteúdo, está eternamente presente no inconsciente coletivo - ou seja, comum a todos os homens - e pode aparecer tanto na teologia egípcia como nos mistérios helenísticos de Miltra; no simbolismo cristão da Idade Média e nas visões de um doente mental, nos dias de hoje. (APUD COELHO, 2008, p. 97)

Nise Silveira, retomando as idéias de Jung, afirma que: 
Arquétipos são matrizes arcaicas que dão forma a impulsos psíquicos comuns ou naturais nos seres humanos. São uma espécie de depósito das impressões superpostas, deixadas por várias vivências fundamentais, comum a todos os humanos, repetidas incontavelmente, através dos milênios. Emoções e fantasias suscitadas por fenômenos da natureza, como medo, prazer, experiências com a mãe ou da mulher com o homem, situações difíceis como a travessia de mares, grandes rios, montanhas etc. Seja qual for a sua origem, o arquétipo funciona como um nódulo de concentração de energia psíquica. Quando esta energia gerada toma forma, temos a "imagem arquetípica" [...] pois o arquétipo é apenas uma virtualidade. (SILVEIRA, 1981, p. 79 )

De acordo com os estudos junguianos, pode-se dizer que arquétipos são modelos de comportamentos universais, ou melhor, estruturas básicas de comportamento existentes na psique humana, que permanecem através dos tempos. Trata-se, portanto, de um conjunto de características que constituem a maneira de ser, expressar-se, comportar-se e sentir do indivíduo. Ademais, os arquétipos não apenas moldam o comportamento, mas também transformam totalmente nossos sentimentos e percepções.

Diante desse pressuposto, observamos no mundo o ressurgimento dos valores e da busca do feminino, simbolizando a necessidade de uma profunda consciência individual e coletiva para renovar a visão de ser, pensar e agir deste ser que se torna cada vez mais mulher.

Nessa concepção, moldada à semelhança da Grande Mãe, a figura da Scherezade piñoniana se torna idêntica à mãe, embora esta já tivesse falecido. Mãe e filha, juntas, se completam na sua transformação como se incorporassem Demeter e Core. É exatamente nesses pólos arquetípicos do Eterno Feminino que a mulher se torna capaz de estabelecer uma renovação infinita, pois o princípio do mistério feminino não diz respeito somente à mulher que descende da própria mulher, mas do homem que está contido nela. E, nesse caso, o Califa representa apenas o elemento masculino indispensável para a fertilidade, pois Scherezade tem o poder de exauri-lo, tendo em vista que a concupiscência manifestada por ele promove, paulatinamente, a perda da sua vitalidade e de seu poder. 
O retorno à Grande Mãe torna-se o prenúncio de uma nova forma de conscientizar, valorizar e validar os valores femininos, podendo estar instaurada entre dois opostos, bem e mal, ou ainda, deusa ou bruxa.

Por outro lado, pode-se dizer, ainda, que Scherezade pode ser considerada uma tecelã, na medida em que entrelaça regularmente palavra por palavra para criar seu repertório. Assim, tece os fios narrativos das histórias para ganhar tempo ao protelar, noite após noite, a morte e, consequentemente, poder libertar-se da situação a que parece estar confinada.

É necessário salientar que se fiar simboliza a construção do destino, então, supõe-se que o desfiar seja um retorno ao passado, com o intuito de refazer o caminho, modificando este destino e, ao mesmo tempo, revelando sentidos múltiplos e inovadores.

Scherezade está configurada na imagem de uma das mais famosas fiandeiras da mitologia grega, conhecida como Penélope, esposa de Ulisses, que, além de tecer, também destecia. Nota-se que o trabalho que era realizado durante o dia era desfeito à noite e, assim, ela mantinha-se protegida dos pretendentes inconvenientes, pois somente se casaria novamente quando terminasse de tecer a sagrada mortalha de seu sogro chamado Laerte. Por isso, não se importava com as censuras dos homens e tecia com fios frágeis e com pontos miúdos, e esta é a razão da demora em virtude do processo lento que durou anos e anos.

Martha Robles (2008, p. 201) ressalta que Scherezade é a fiandeira que entrelaça com a mais perfeita poesia os fios do proibido e do permitido, do profano e do religioso, do quotidiano e do sobrenatural, da prosa e do verso, da dor e da felicidade, a fim de oferecê-los a todas as gerações como um ato de amor.

Então, como as grandes mulheres da humanidade, a Scherezade de Piñon passa a incorporar o mito de Penélope, na medida em que tece com palavras:

Com o tear e o algodão entre os dedos, ela ia afinando os fios para fazer com eles, ao final, um tipo de manta capaz de proteger os ouvintes do frio das noites no deserto. Scherezade, porém, afligia-se sob a pressão dos méritos que lhe eram atribuídos. Pouco afeita às homenagens, recusava ser a tecelã que Fátima lhe atribuía. (PIÑON, 2006, p. 37) 
Convém enfatizar que tal artimanha é analisada por Pierre Brunel (1997) como uma forma de defesa arquitetada pela mitológica personagem, salientando que

[...] a escolha de Penélope por esse trabalho feminino singular, a fim de acalmar seus pretendentes, torna-a a nossos olhos diferente daquela que habitualmente reconhecemos como emblema de fidelidade conjugal. Tecer, fiar dão-lhe tempo para fabricar suas próprias defesas contra o homem, o esposo e o pai. Para ela, é o tempo de sublimar o medo. (BRUNEL,1997, p. 376).

Considerando que Penélope desfia para se instrumentalizar contra aquilo que a atemoriza, ela se fortalece, assim como a Scherezade de Nélida Piñon, ao (re)criar e/ou inventar as histórias para poder sobreviver e se manter viva, pois é a única capaz de vencer o poderoso Sultão e livrar as demais jovens do martírio.

Nota-se que tal fato é uma espécie de ruptura com o passado aprisionador e patriarcal, pois permite à personagem revisitar-se sem medo, uma vez que não teme a morte (PIÑON, 2006, p. 7), isto é, conhecer sua própria essência, vestindo-se inúmeras vezes com o véu no afã de ar puro.

De acordo com Chevalier \& Gheerbrant (2002, p. 68-69), a simbologia do ar, geralmente, encontra-se associada à espiritualização. É um símbolo sensível da vida invisível, um móbil universal e um purificador:

[...] o ar é o meio próprio da luz, do alçar voo, do perfume, da cor, das vibrações interplanetárias; é a via de comunicação entre a terra e o céu. $A$ trilogia do sonoro, do diáfano e do móbil é... uma produção da impressão íntima do alívio, de alijamento. Ela não nos é dada pelo mundo exterior. É conquista de um ser de outrora pesado e confuso que, graças ao movimento imaginário, e escutando as lições da imaginação aérea, se tornou leve, claro e vibrante.

Fica nítido em Vozes do deserto que a personagem, ao desvencilhar-se daquilo que lhe prendia, torna-se livre e leve como a configuração do tecido de um véu. 
Já para Cirlot (1984, p. 598), o véu significa ocultação de certos aspectos da verdade ou da divindade. Diante dessa percepção, Nélida descreve o mistério encerrado por trás dos véus, expondo o significado deles quanto ao uso pelas mulheres no cotidiano, como uma forma de proteção, de usar a imaginação, de estímulo ao jogo erótico, de disfarce, de pregar recato, de refúgio e de fuga da tirania masculina e da própria realidade que as circunda, conforme citação abaixo:

[...] os véus, para as irmãs, integraram-se imediatamente à esfera da imaginação. Persuasivos por natureza, eles guardavam e exibiam o que estivesse sob o foco da atenção masculina... preservavam as incertezas dos sentimentos femininos... escondiam, permitiam igualmente que as irmãs, ao resguardo deles, se refugiasse, mesmo em pensamento... serve de estímulo ao jogo erótico. (PIÑON, 2006, p. 31)

[...] Com eles nos rostos, certas de não serem reconhecidas, fogem à tirania do pai e do Califa. Como se, ancoradas em terras exóticas, cessasse o perigo de serem trazidas de volta ao serralho, enquanto confiam que os olhos, apesar de tão expressivos, confundam 0 observador, dizendo o contrário do que sentem. (PIÑON, 2006)

O véu pode adquirir uma outra configuração, o de vestimenta e, segundo o dicionário de símbolos de Chevalier \& Gheerbrant (2002), a vestimenta torna-se um símbolo externo, a forma (in)visível de a mulher instaurar a individualidade. Desta maneira, a mulher ao usar o véu como vestimenta reencontra, através de símbolos, o lugar que acredita ocupar no mundo, ou seja, o próprio ser da mulher, consciência de si mesma atingindo o seu ideal. Assim, a vestimenta apresenta-se como significação do caráter profundo daquele que a veste. Por isso, a troca de tecido anuncia a passagem de um mundo ao outro, ou melhor, representa as disposições interiores necessárias para progredir etapa por etapa, até a realização final - sua ascensão no mundo, em particular, no mundo dos homens.

É preciso acrescentar que o apreço pelos véus faz parte de uma cultura que os consagra, pois a falta do véu significa estar sem a devida proteção, sujeitando-se à 
claridade, expondo os sentimentos e permanecendo na mira, ou melhor, à mercê da cobiça masculina.

Nessa linha de reflexão, os símbolos relacionados com o mito e o arquétipo exprimem uma linguagem simbólica, mediadora entre o espaço imaginário e o espaço real, capaz de engendrar comportamentos humanos, situações e, acima de tudo, dar visibilidade à mulher e propagar a literatura pelo mundo todo. 


\section{CAPÍTULO 4}

O MUNDO DAS MULHERES

I have learned through the years that one voice alone is insufficient.

Nélida Piñon 


\subsection{O PODER DA PALAVRA: AS VOZES DO ROMANCE}

Neste item, e a partir dos estudos do narrador configurados por Oscar Tacca (1983), Walter Benjamin (1994) e Theodor Adorno (2003), serão analisadas as vozes que permeiam a narrativa de Vozes do deserto e que, associadas às investigações até aqui existentes, contribuíram para vislumbrar a construção da personagem feminina Scherezade, quanto para a compreensão da obra como um todo, pois "as palavras formam um amálgama inquebrantável” (PIÑON, 2006, p. 25).

Para Tacca (1983, p. 61), o mundo do romance é constituído por inúmeras vozes, em princípio, a do autor que dá voz para o narrador, que a empresta para as personagens e que, consequentemente, são viabilizadas ao público leitor. Então, uma vez que o leitor faz parte da tríade configurada pela estética da recepção, obra, autor e leitor, tem um papel primordial e deve estar atento às peripécias da narrativa, a fim de emitir ou não seu ponto de vista a respeito de uma história. Apesar de o narrador não ter sua origem revelada, ele mantém uma relação de proximidade e confiabilidade com o leitor.

O referido autor salienta que a função do narrador é informar. Ademais, não lhe é permitida a falsidade, nem a dúvida, nem a interrogação nesta informação. Apenas varia a quantidade de informação (TACCA, 1983, p. 64). Pode-se dizer que a voz do narrador constitui a realidade do relato, tornando-se o eixo do romance. Sua missão é contar, ou melhor, saber como contar, pois se situa no plano da audição e da consciência. Nesse sentido, o crítico mostra que, assim como existe uma livre seleção quanto ao "como contar", existe forçosamente uma decisão prévia quanto ao "como saber". E esse "como saber", a partir da perspectiva (ponto de vista) do narrador, é que vai gerar aquilo que saciará nossos anseios, desejos e expectativas: a criação literária.

Walter Benjamin (1994) salienta que o narrador é aquele que narra para que o outro possa retirar um proveito para sua própria vida. A esse propósito, Theodor Adorno, quando escreve "A posição do narrador no romance contemporâneo" (2003), visa estabelecer uma espécie de diálogo com os textos de Benjamin em que consta a figura do narrador como a entidade narrativa que se pergunta sobre si mesma, sem 
satisfazer-se com as respostas que encontra e, mais do que nunca, com as invenções tecnicistas, as descobertas psicanalíticas, as tendências filosóficas, o homem aprendeu a dominar os outros homens e a natureza em proveito próprio (ADORNO, 2003, p. 5564).

Vozes do deserto é um romance multifacetado, polifônico, na medida em que há a participação de várias vozes que se vão alternando na narrativa. Dentre elas, primeiramente, destacamos a do narrador onisciente e onipresente que predomina na maior parte narrativa. Então, é por meio dela que o leitor sabe tudo e a tudo consegue ver. Pode-se dizer que esse narrador é um profundo conhecedor das personagens, do enredo, dos pensamentos, sentimentos e emoções, enfim, da intimidade, por ele revelar a história visível e uma outra invisível que está camuflada. Assim, é uma voz que não nos dá trégua, deixando-nos tomar ciência de tudo aquilo que ocorre por detrás dos bastidores, revelando as reais circunstâncias e experiências vivenciadas pelo mundo feminino.

Desse modo, o narrador apresenta Scherezade como uma mulher destemida, guerreira e corajosa, capaz de lutar e solucionar todos os problemas para alcançar seus sonhos e objetivos. Assim, desde a abertura do romance, verifica-se o discurso indireto por meio do qual conseguimos conhecer os anseios de Scherezade a partir da tomada de decisão de se casar com o Califa; posteriormente, a desaprovação da família pelo ato consumado [enlace matrimonial], a repulsa sentida ao ser tocada por um homem que não ama e, acima de tudo, frio; o íntimo desejo de libertar-se do holocausto; o desejo da liberdade; o medo da morte que a aterroriza; a angústia de buscar o que contar toda a noite para garantir a luz e o brilho da manhã seguinte. Enfim, tomamos conhecimento de tudo aquilo que compete a esse narrador informar sobre a situação que envolve a personagem:

[Schrezade] Tenta convencer o pai de ser a única capaz de interromper a sequência de mortes dadas às donzelas do reino. Não suporta ver 0 triunfo do mal que se estampa no rosto do Califa. [...] (PIÑON, 2006. p. 07) 
O pai [...] sem envengonhar-se, lança mão de todos os recursos para convencê-la. Afinal, a filha lhe devia, além da vida, o luxo, a nobreza, a educação refinada. [...] Também Dinazarda, a irmã mais velha, tenta dissuadi-la. Previa-a incapaz de dobrar a vontade do soberano. (PIÑON, 2006, p. 07-08)

O narrador inicial [onisciente] nos fornece uma rápida contextualização da história, dando ao leitor as informações necessárias para que ele possa tomar ciência dos fatos, visualizando, assim, cada personagem na sua intimidade. Ademais, aproveita o ensejo para tecer descrições quanto às características físicas, à ambientação, ao uso de vestimentas, porém, não tece nenhum tipo de julgamento, isto é, apenas conta, cumprindo a função do narrador estabelecido por Tacca (1983).

Cabe lembrar, também, que esse narrador é objetivo e sabe aquilo que deseja contar e, nas palavras de Tacca, isto determina a perspectiva do romance, pois o que importa é o "como" ele conta, tornando-se indispensável para a compreensão da obra.

Desta maneira, o narrador não se exime de mostrar as fraquezas de Scherezade, talvez sob o pretexto de enaltecê-la, uma vez que ela sai vencedora a cada manhã.

Neste âmbito, Tacca enfatiza que a relação entre narrador e personagem pode ser definida, do ponto de vista do conhecimento ou da informação, por três tipos: onisciente, equisciente e deficiente. O primeiro se refere ao narrador que detém um conhecimento maior do que suas personagens. Já ao segundo é atribuído um nível de conhecimento igual ao de suas personagens. No terceiro, evidencia-se um saber do narrador inferior ao de suas personagens.

Então, vejamos algumas passagens em que o narrador onisciente deixa explícito o seu conhecimento sobre diversos fatos da história, como, por exemplo, revelar o pensamento da personagem Scherezade na hora do banho, uma vez que esta reflete sobre a situação em que se encontra após o coito e uma noite inteira de fabulação:

[...] O que a motiva a perguntar-se que sina a sua, de saber mais que os comuns dos mortais! De afligir-lhe com segredos, códigos, entraves, que os humanos foram engendrando como forma de criar civilização que coubesse integral dentro dos muros de Bagdá? (PIÑON, 2006, p. 53) 
Outro exemplo nítido diz respeito às inquietações que perturbam o Califa em relação a traição da sultana, no passado:

A respeito de reinar sobre o califado de Bagdá, a desonra, que ainda hoje o persegue, inflige-lhe noções distorcidas da realidade. Como confiar na figura feminina que, mesmo sob vigília, o envergonha diante dos súditos? Jurara que nenhuma mulher voltaria a traí-lo, mas para manter intacta a palavra havia que condenar à morte cada esposa que the aquecera o leito. (PIÑON, 2006, p. 71)

Observamos que este narrador tem livre arbítrio para transitar nos lugares mais longínquos, tecer informações e comentários sobre outras culturas, em especial, a cultura árabe e abássidas anteriores, explanando que o Califa age ao contrário do famoso e lendário Harum Al-Rachid, sultão lembrado por seus inúmeros disfarces, ou seja, "o nobre ancestral que, de tanto carecer de verdade e da mentira, ia ao mercado disfarçado de oleiro, de mendigo, de mercador, forçando os súditos a the denunciarem a prepotência e os erros" (PIÑON, 2006, p. 143). Nota-se que o sultão de Nélida se recusava a ter uma atitude semelhante, pois preferia ficar 'entocado' no ambiente palaciano sob o poder das palavras de Scherezade, uma vez que estas podiam transportá-lo para fora do palácio e/ou para qualquer outro lugar.

Seguindo essa trajetória cultural, o narrador ainda descreve o reino de Bagdá e, inclusive, menciona as reações das pessoas quando Scherezade toma a decisão de se casar com o Califa para evitar uma maior tragédia:

O debate deixara os limites dos aposentos, das dependências dos serviçais, para circular pelo submundo de Bagdá, constituído de mendigos, encantadores de serpentes, charlatães, mentirosos que no bazar adotavam formas obscenas e jocosas enquanto propagavam a notícia da filha do Vizir, a mais brilhante princesa da corte, que, tendo em mira salvar as jovens das garras do Califa, decidira casar-se com ele. (PIÑON, 2006, p. 08)

[...] Comovia a velha Medina que, de hábito, lidava com o engodo e a burla. Os sentimentos que a jovem inspirava faziam com que teólogos, filósofos, 
ilustres tradutores, aí incluindo seus mestres, se reunissem pesarosos diante das portas do palácio do Vizir, e ajoelhados, com os olhos postos em direção a Meca, escandissem versículos inteiros do Corão com o propósito de fazê-la desistir de semelhante ato. (PIÑON, 2006, p. 09)

Paulatinamente, a história vai sendo desvelada pelo leitor que busca assumir o seu papel na narrativa e estabelecer as devidas inferências para a compreensão da obra. A este exemplo, cabe lembrar o momento em que o Califa tem pensamentos sobre Scherezade e sobre as diversas personagens que nela habitam. A intenção é desvendar os segredos e mistérios que circundam o ser feminino. No entanto, ele não consegue penetrar nesse universo das mulheres, pois não confia na princesa. Ademais, acredita no poder de vingança do sexo feminino, pois, sem ao menos esperar e sem se despedir, ela poderia desaparecer do palácio. Então, eis a reflexão do Califa: "estaria ela amuada, disposta a deixar-Ihe um rastro de ódio, um legado que Dinazarda e Jasmine herdariam?" (PIÑON, 2006, p. 160). Nota-se que estas informações fornecidas pela voz narrativa do Califa servem como uma espécie de premonição para que o leitor atento possa tomar ciência daquilo que está prestes a acontecer no desfecho final: a fuga de Scherezade do palácio, cedendo a Dinazarda o seu lugar "na cama" do Sultão, enquanto a Jasmine reserva o papel de contadora de história.

Pode-se dizer, ainda, que o narrador é um demiurgo, pois nos fornece um panorama da história, informando os pensamentos e conversas das personagens, os costumes, as tradições, a cultura, os diálogos e os questionamentos internos como estratégias da voz narrativa, devido às pistas dos acontecimentos futuros que, atreladas ao passado, têm o poder de enlear o leitor no presente, mantendo-o preso e também cúmplice da narração.

Nesta perspectiva, Walter Benjamin (1994) afirma que o narrador é um ser comunicante que interage com seus ouvintes. Ademais, o autor associa essa entidade àquela de quem fala de modo a servir de exemplo a quem ouve. Portanto, o narrador figura entre os mestres e os sábios. Ele sabe dar conselhos, pois recorre ao acervo de toda uma vida de experiência própria e alheia. Além disso, é a figura na qual o justo se encontra consigo mesmo (BENJAMIN, 1994, p. 221). 
No romance, o poder da palavra está representado pelas vozes que engedram as histórias de que Scherezade se vale para dar conta da situação em que se encontra e poder libertar-se das amarras patriarcais dominantes:

[...] Pois sua função, a fim de salvar-se, previa considerar o peso de cada palavra na frase, sem esquecer, para isto, de acrescentar ossos, gorduras, paixões aos personagens, frutos de sua invenção. A eles confinando o encargo de abrandar o coração empedernido daquele homem. [...] Com voz de flauta de alaúde, ela cultua volutas verbais que desestabilizam a realidade sobre a qual o Califa governa. (PIÑON, 2006, p.27-28)

É válido observar que outras vozes fazem-se ecoar aos ouvidos dos leitores, cedendo espaço narrativo, nesse momento, para a personagem Scherezade, que encarna a figura do narrador, pois esta tem o verbo fácil e o dom da palavra, uma vez que sabe dar ouvidos ao passado e tem olhos voltados para o futuro. Então, pode-se dizer que nela se congregam os dois tipos de narradores propostos por Walter Benjamin na obra de Nikolai Leskov (1994, p. 199): a voz do camponês sedentário, pois ela possui o germe da sensibilidade para acolher a voz dos ancestrais que colaboraram com uma educação esmerada e todo um conhecimento que guardara na memória cultural; e a voz do marinheiro comerciante, que traz para casa o saber das terras distantes, adquirido por meio das mil e uma histórias sem fins que lhe permitem estar aqui e acolá. Assim, serão inseridos na sua narração tanto os fatos testemunhados quanto aqueles vivenciados pela própria experiência do embate corporal cotidiano.

Nesta concepção, Nélida parece utilizar a combinação desses dois tipos de narradores no mesmo ser para intuir o enlace do passado com o futuro, com vistas a compor o presente.

Esta personagem-narradora demonstra os mandos e desmandos não somente na arte de narrar, mas, sobretudo, no que concerne à personagem masculina [o Califa] como se ela detivesse o poder em suas mãos, pois a intenção é "[...] deslocá-lo do sexo para as palavras, em impingir-lhe a lenta agonia advinda da sua manha narrativa" (PIÑON, 2006, p. 43). 
A voz da personagem Dinazarda também torna-se marca irrefutável, pois é a partir de seus sussurros mal interpretados após a cópula do Califa com Scherezade que ela [Dinazarda] abre alas para a primeira narrativa da irmã, quando a vê prostada na cama. Disposta a lutar pela irmã, Dinazarda surpreende o Califa junto ao leito nupcial, hora em que:

Murmura sons que o Califa mal registra, mas cujas palavras, corajosas, despertam-lhe a vontade de ouvi-la. Dinazarda aumenta o tom da voz, para só emudecer depois de arrancar do Califa a promessa de ouvir Scherezade. Só então, ajuda a irmã a contar sua primeira história. (PIÑON, 2006, p. 23)

Na verdade, é Dinazarda quem efetua a coerência entre as histórias, enquanto Scherezade navega por um mar de imprevisibilidade, pois, "a cada palavra da jovem, [o Califa], esquece-se da humilhação infligida pela mulher que o traíra com o mais miserável dos serviçais" (PIÑON, 2006, p. 195). Ademais, "intui que seu poder, frente ao império narrativo de Scherezade, vale pouco, o que lhe dá motivo de ameaçá-la de novo com a morte aos primeiros sinais da aurora" (PIÑON, 2006, p. 197).

A verdade é que Scherezade "cultua volutas verbais que desestabilizam a realidade sobre a qual o Califa governa..." (PIÑON, 2006, p. 28) e isto faz com que ele vá perdendo a força e, consequentemente, a voz autoritária emudece para ceder lugar ao outro ser que subverte a ordem patriarcal e prova que o destino de uma mulher pode ser outro,

Pode-se dizer que, ao ouvir Dinazarda, o Califa passa a querer ouvir Scherezade, pois, no seu discurso, Dinazarda garante ao Califa que "a palavra da irmã era uma espécie de casulo, de onde sairia um dia, na hora certa, o bicho da seda" (PIÑON, 2006, p. 25).

As palavras de Dinazarda permitem inferir a existência de uma narrativa dentro da outra, porém, este não dito cabe à imaginação do leitor realizar, uma vez que este é convocado pelo narrador como um outro contador de histórias que dará a ela mais vigor interpretativo e crítico. 
Nota-se que, em Vozes do deserto, há inserção de outras formas narrativas como diálogos, bilhetes, fábulas e contos, configurando a metalinguagem, ou melhor, a ficção dentro da ficção. A este respeito, é válido observar as palavras de Marthe Robert a respeito da inserção de uma narrativa dentro de outras narrativas:

Da literatura, o romance faz rigorosamente o que ele quer: nada o impede de utilizar para seus próprios fins a descrição, a narração, o drama, o ensaio, o comentário, o monólogo, o discurso; nem de ser a seu bel prazer, pouco a pouco ou simplesmente, fábula, história, apólogo, idílio, crônica, conto, epopéia; nenhuma prescrição, nenhuma proibição pode delimitar a escolha de um sujeito, de um cenário, de um tempo, de um espaço; a única proibição à qual ele se submete, em geral, é aquela que determina sua vocação prosaica; porém, nada o obriga absolutamente a seguí-la rigidamente, ele pode, se julgar pertinente, inserir poemas ou simplesmente ser "poético". (ROBERT, 1981, p. 15)

É fato que, na presente escritura, a literatura torna-se um espaço amplo de liberdade, capaz de gerar uma força e todo um esforço para salvar a narrativa, as personagens, as contadoras, as narradoras, enfim, as vozes dessas mulheres que souberam fazer a diferença e eregir suas vidas pelos desígnios divinos da palavra em tempos pós-modernos. Então, por falar delas, ainda resta mencionar Jasmine, a criada, que, por saber tão bem esgueirar-se pelos corredores do palácio e pela Medina, estabelece-se como um ponto de equilíbrio entre as duas irmãs, ao trazer-lhes notícias auspiciosas para a futura narração:

À espreita, Jasmine vaga a esmo pela Medina, com dificuldades de selecionar os relatos que ouve. Mas, um pouco antes do anoitecer, tem tudo à mão. Com o farnel cheio de provisões, deposita diante de Dinazarda doces queijos, palavras, os produtos da terra, sob forma de histórias. (PIÑON, 2006, p. 182)

Jasmine, em sua condição de escrava, reconhece o valor da sabedoria contida no ato de narrar e, portanto, torna-se a voz mais recente como contadora de histórias. 
Por outro viés, ouvimos a voz do Califa que, aparentemente, concentra força, poder e violência. Porém, com o estrategema lançado por Scherezade de contar histórias ininterruptas, a estrutura masculina dominante cai por terra, ou seja, é desestabilizada pelo poder da palavra feminina.

A insistência de liderança do poder feminino configurado pelas mulheres pinõnianas ultrapassa os limites palaciano, permitindo que uma delas [Jasmine] consiga percorrer, livremente, as ruas do mercado. Então, deparamos com outras vozes, agora, a do derviche, um velho homem cego, cuja voz ressoa os uivos da imaginação, resultando a faculdade de contar histórias por horas sem dar prova de cansaço.

O derviche finge ignorar sua presença [Jasmine], mas, seguindo seu instinto apurado, demonstra conhecer a razão de sua visita. [...] Mas com que história agora cativar uma mulher que lhe pagara antes mesmo de estipular o valor do seu trabalho? (PIÑON, 2006, p. 242-243)

Atenta às comiserações do derviche, Jasmine controla a sede. Acompanha como cria um cotidiano ao qual ela deve associar-se se quer, de verdade, ouvir suas histórias. (PIÑON, 2006, p. 245)

Seguindo este percurso narrativo, visualizamos as vozes dos mercadores que, no trânsito de ir e vir à Medina, fabricam histórias que, muitas vezes, podem ser intercaladas com as das outras personagens como Harum al Rashid, Simbad, o Marujo, Aladim e o Gênio, entre outros que ajudaram a construir o enredo.

Essa diversidade de vozes narrativas faz com que o leitor consiga localizar o fio condutor que sustenta a trama do texto, sendo levado a participar e ampliar o horizonte de leitura a partir de uma nova visão da história de Scherezade.

Desta maneira, temos a representação de uma nova mulher no século XXI, graças aos plenos poderes das vozes narrativas, em especial, do narrador onisciente que permitiam-lhe o livre acesso entre o visível e o invisível, pois, todos os dados lhe eram lícitos tais como: fatos, pistas, informações, confidências, descobertas, sugestões e ou, até mesmo, suposições. 
Convém enfatizar, ainda, outros teóricos que nos auxiliaram a repensar e analisar as artimanhas do narrador de Vozes do deserto que, em consonância, com a atuação do leitor possibilitaram uma maior compreensão das personagens bem como da obra. Dentre eles, destacamos Salvatore D'Onófrio (2006), Wayne Booth (1980) e Silviano Santiago (1989).

Com certeza, a abordagem teórica sobre o estudo do narrador serviu para aprofundar a reflexão sobre o poder da palavra, da narrativa e, principalmente, o poder da imaginação como forma de liberdade do ser humano.

Para finalizar, pode-se dizer que essas vozes expressas no romance são aquelas vozes que ecoam no deserto da existência, buscando o sopro de vida para manter sua própria sobrevivência. São vozes que ecoam no deserto de uma linguagem talvez desgastada, ou até mesmo, silenciada pelas marcas do tempo, porém, é por intermédio da linguagem que podemos nos afirmar e reafirmar neste espaço tido como "infértil", mas capaz de germinar, com uma gota de otimismo, uma nova visão de mulher. Mulher que se torna mulher, sinônimo de imaginação, de força, de insubordinação, de insubmissão, de subversão e, acima de tudo, de transgressão, pois se nota nesta nova mulher um "ser saindo da imanência à transcendência, digo, uma consciência realizadora que deseja projetar-se no mundo, com o mundo e para mundo" (HEIDEGGER, 2005, p. 27). 


\subsection{MULHERES TRANSGRESSORAS: EM BUSCA DA VISIBILIDADE}

É com audácia que iniciamos este item dizendo: Bem Aventuradas sejam as mulheres que desafiaram o mundo da escrita e tiveram a coragem ou, melhor ainda, a ousadia de promulgar a palavra em um universo até então predominantemente masculino. Mulheres de todas as cores, de todas as formas, de várias idades, aquelas consideradas como deusas, anjos, fadas, demônios, enfim, mulheres que se arriscaram nessa aventura do saber/poder para revelar a sua condição à sociedade. Então, é por meio de uma imaginação prodigiosa e reveladora que buscar-se-á alçar voos em outros patamares: 0 da superioridade

Numa perspectiva histórica, a trajetória do movimento feminino legitimou muitas transformações sociais, políticas e culturais que, em certa medida, contribuíram para alterar o cenário nacional e internacional no que diz respeito às questões de mulheres.

Então, se voltarmos no túnel do tempo, perceberemos o quanto significou a luta das mulheres pelo direito ao voto e à vida política, posteriormente, ao acesso ao conhecimento, à informação, ao saber acumulado das mulheres sobre si mesmas, conforme se pode observar na ginocrítica de Elaine Showalter e nas políticas identitárias de Virgínia Woolf e Simone de Beauvoir, Susan Bordo, Judith Butler, Susan Standford Friedman, Donna Haraway, mulheres que, entre outras, ajudaram a reconhecer a 'outridade do paradigma da mulher', bem como sua alteridade 'positivamente outra', ao traduzirem a consciência de que o feminismo se instituiu como emergente e em uma 'nova fronteira', capaz de resistir aos discursos hegemônicos dominantes.

$\mathrm{Na}$ verdade, a luta das mulheres foi intensa, mas produtiva, porque ganhamos "paulatinamente" força e poder nas diversas áreas do conhecimento, demonstrando que essa relação saber/poder, utilizada num sentido foucaultiano, sempre esteve implicada, ou seja, que "não há relação de poder sem constituição correlata de um campo de saber, nem saber que não suponha e não constitua ao mesmo tempo relações de poder" (FOUCAULT, 2003, p. 27). 
$E$, assim, as mulheres transgrediram os limites das fronteiras do tempo e do espaço em busca de uma maior visibilidade e liberdade de decisão nos diversos assuntos relacionados a si mesmas, à questão da família, do trabalho, da reprodução, da sexualidade, da linguagem e do próprio corpo. Não cabe aqui, porém, definir em pormenores cada um desses conceitos, apenas associá-los à nossa pesquisa.

É válido observar que as mulheres firmaram uma premissa de autonomia, ou seja, a de que as mulheres podem e devem constituir-se e instituir-se como sujeitos na história, uma projeção/construção ancorada em suas emoções, sentimentos, necessidades e experiências da vida cotidiana.

Nessa direção, cabe destacar a relevância da escritora Nélida Piñon em narrativas de autoria feminina, por ela prestigiar mulheres que fizeram a diferença de ser e estar no mundo. Uma das representações pode-se dizer que provém da Scherezade oriental à Scherezade brasileira e se estende a todas as mulheres que sentiram na própria pele o que é nascer e tornar-se mulher.

Nesse sentido, Judith Butler esclarece:

Se há algo de certo na afirmação de Beauvoir de que ninguém nasce mulher e sim torna-se mulher decorre de que a mulher é um termo em processo, um devir, um construir de que não pode dizer com acerto que tenha uma origem ou um fim. (BUTLER, 2003, p. 58-59)

Percebe-se que a mulher é um ser em constante evolução e que, a partir daí, a criação de um sujeito particular possibilita uma reflexão para a caracterização do universal, pois permite vislumbrar que ela faz parte de um mundo que é das mulheres. No entanto, a afirmação "o mundo é das mulheres" torna-se polêmica, pois parece dizer tudo, mas é algo ainda muito complexo por se tratar de um universo feminino que busca libertar-se do fardo pesado deixado pelos resquícios de uma sociedade patriarcal e, acima de tudo, machista.

Então, temos a formação de uma sociedade de mulheres que vem substituindo paulatinamente o mundo dos homens em todas as áreas de conhecimento. Mulheres que já não são mais "vítimas" e, portanto, vistas como seres inferiores ou de sexo frágil. 
Compreende-se melhor que elas consolidaram suas forças para alçar voos de liberdade, de justiça e de direitos igualitários, eliminando a oposição binária entre homens e mulheres.

Nesse sentido, as mulheres são portadoras de uma nova representação do mundo e de uma experiência humana física e psíquica capaz de as transformar em sujeitos da história, descontruindo a visão estereotipada de mulher como 'Amélia' ou 'rainha do lar', confinada no ambiente doméstico ou entre "quatro paredes", reprodutora da vida e responsável pela educação dos filhos.

Segundo Alain Touraine (2007), as mulheres de hoje têm consciência de estar descobrindo e até construindo um mundo novo, de possuir uma subjetividade, de poder dizer eu e de construir-se como um sujeito.

Então, pode-se dizer que as vozes dessas mulheres já podem ser ouvidas nesse espaço fértil em que se reconhecem como uma pluralidade de identidades sociopolíticas e culturais, sem imposições de regras, normas e valores apregoados por uma sociedade patriarcal dominante durante longos anos.

Portanto, são mulheres mais conscientes de sua própria existência de ser e estar no mundo e que transgrediram a linha tênue do tempo e espaço em busca de sua liberdade, liberação e libertação, ou seja, da criação de uma nova cultura reservada ao mundo das mulheres.

A representação da personagem Scherezade, eleita por Nélida Piñon, muda o foco de luz que incide sobre as mulheres na cultura ocidental, buscando identificar dados de uma outra sensibilidade, de percepção da vida cotidiana, expressos literariamente nos textos e comuns à experiência delas, quer seja interior, corporal, social, político e cultural.

Ao pensar e questionar-se sobre essa nova visão, as mulheres se libertam e entram em cena para atuar em um espaço amplo, fértil e significativo na historiografia literária e produzem obras que trazem à lume a situação da mulher, que fora escamoteada pelo restrito mundo dos homens.

Então, no que concerne aos estudos sobre a literatura de autoria feminina, Almeida, baseada nas reflexões de Showalter, pondera que: 
A escrita se torna, então, um espaço alternativo através do qual se possa [...] retomar como uma área de questionamento o espaço do outro, as brechas, os silêncios e ausências do discurso e da representação aos quais o discurso feminino tem sido relegado. A escrita se transforma numa possibilidade, num espaço que serve de impulso subversivo para a expressão de uma voz feminina que encontra em sua própria alteridade os meios de evasão. Portanto, para essas escritoras, uma escrita através, sobre e proveniente destes "espaços de alteridade" se desenvolve como uma estratégia altamente transgressiva. (ALMEIDA apud ZOLIN, 2003, p.195-196)

Considerando o percurso trilhado pelas mulheres piñonianas e retratadas em Vozes do deserto, nossa leitura permite inferir o processo transgressor e emancipatório caracterizado pelo discurso da autora.

Assim, focalizamos a tríade composta por Scherezade, Dinazarda e Jasmine. Convém enfatizar que, a partir daí, Nélida Piñon nos propicia resgatar as características de cada uma das fases de narrativa de autoria feminina estabelecida por Showalter (1985), mencionadas brevemente no terceiro capítulo: as fases feminina, feminista e fêmea.

Embora haja murmúrios e desaprovações de toda a corte pela decisão de Scherezade de se casar com o poderoso Califa para salvar todas as jovens do reino, ela se sujeita ao papel de esposa submissa e, consequentemente, de mulher objeto que pode ser manuseada pelas mãos deste ser cruel, a seu bel prazer. Então, devido ao medo que a aterroriza, nesse primeiro momento, ainda não transparece a predominância de uma voz ativa. De acordo com as convenções tradicionais, este papel é atribuído ao sexo feminino, uma vez que está associado à primeira fase da narrativa de autoria feminina, ou seja, a fase feminina em que ocorre a repetição dos padrões culturais arraigados pelo poder dominante patriarcal.

Seguindo esta linha reflexiva, deparamos com uma outra personagem, Dinazarda, irmã de Scherezade, que aceitara ser cúmplice no projeto de contar histórias para garantir a sobrevivência delas mesmas e, inclusive, das demais mulheres, ludibriando o Califa e, consequentemente, humanizando-o. Já a personagem Jasmine, serva leal e companheira das irmãs, é quem estabelece o elo de ligação entre as irmãs. É a representante dos povos do deserto que têm as suas vozes caladas, mas ela 
aprende o ofício da arte de narrar com Scherezade. Ambas se enquadram nesta mesma fase por acompanharem a personagem Scherezade nessa trajetória. Portanto, estas mulheres se identificam umas com as outras e se unem por meio de uma "cumplicidade imanente", num espaço até então ocupado pelo poder masculino, mas que garante a atenção e a presença feminina.

Desse modo, é necessário acrescentar que a personagem Scherezade vai sofrendo na narrativa o processo de desnudamento. E a maneira como ela é construída nos remete ao modelo da segunda fase, isto é, a fase feminista, por trazer à tona discussões e reflexões sobre a mulher, seus sentimentos, emoções, enfim, sobre suas experiências nos diversos contextos em que protesta por uma vida melhor e mais digna, promovendo, assim, a ruptura em relação ao modelo patriarcal, ao tomar certas medidas e decisões para mudar seu destino e, posteriormente, sua vida.

Em relação às outras duas personagens, Dinazarda e Jasmine, não há manifestação de mudanças significativas, embora elas apresentem o desejo de substituir Scherezade algum dia em ações, gestos e palavras. Na verdade, uma vive em função da outra, pois elas se complementam e colaboram com a sua performance e construção. Ademais, juntas elas representam a união de perspectivas e ideais femininos, a coletividade, anunciando um caminho capaz de gerar força, luz e vida para todas as mulheres.

Diante do exposto, chegamos a última fase, ou melhor, a fase fêmea (mulher) tratada por Elaine Showalter, cuja predominância reincide sobre Scherezade. Assim, esta vem para corporificar o modelo de personagem feminina, ou melhor, da mulher contemporânea da literatura feita por mulheres no século XXI.

Pode-se dizer que é, exatamente, sobre esses aspectos que a personagem Scherezade se debruça na narrativa, ao demonstrar uma constante preocupação com a situação feminina na vida cotidiana. Assim, ela luta para firmar-se como mulher e poder aspirar a um novo lugar no mundo, bem como na historiografia literária. $E$ isto só é possível com o poder da palavra, uma vez que é nela que se inscreve o poder para edificar o mundo das mulheres.

$\mathrm{Na}$ verdade, o Califa é vencido pelo poder da palavra de Scherezade e, consequentemente, é destituído de seu poder imperial, passando a vivenciar outras 
situações, interiorizando valores primordiais à existência humana. Portanto, ela foge do jugo do Califa, ficando livre da ameaça de morte e do casamento para encontrar a tal liberdade. Vai viver com Fátima, ama de criação, em algum lugar do futuro, uma vez que se recusa a dizer seu itinerário para, supostamente, poder vivenciar outras relações afetivas e desfrutar de um final feliz.

O desfecho final marcou uma espécie de positividade não só para Scherezade como também para todas as demais personagens: Dinazarda ocupa o lugar de Scherezade na cama, como ela almejava desde o princípio; Jasmine passa a ter voz, o que não tinha como simples escrava; o Califa supera a traição:

[...] graças às suas suntuosas descrições recuperara o ânimo de viver. $\mathrm{O}$ califado já não Ihe parecendo tão enfadonho quanto antes. Sem mencionar que aprendera a perdoar as mulheres, graças às histórias de Scherezade considerar homens e mulheres parceiros narrativos. (PIÑON, 2006, p. 349)

Apesar de Dinazarda e Jasmine vivenciarem essa nova realidade, elas permanecem estáveis e sem perspectivas de maiores pretensões, pois ainda se encontram sob a mira do olhar e poder masculino. A estas personagens parece estar vedado daquilo que Ihes pertence de direito: a liberdade, pois mudarão os tempos, mas elas continuarão a fazer parte desse sistema coercitivo e patriarcal, de forma cíclica.

Por fim, pode-se dizer que o romance Vozes do deserto está situado na fase fêmea (mulher) da literatura de autoria feminina estabelecida por Elaine Showalter, pois se observa uma preocupação da mulher consigo mesma, de reconhecer-se e autorreconhecer-se como tal, ser diferente em relação ao sexo oposto, buscar sua própria identidade, autonomia, independência, liberdade e a razão de ser e estar no mundo. Além disso, essa fase possibilita afirmar a alteridade da mulher, promovendo interrogações sobre o outro, sobre o autor, sobre o leitor, enfim, sobre a obra como um todo, admitindo outras e novas perspectivas, pois "[...] nós temos uma espécie de teimosia do mundo referencial, temos uma espécie de permanência desse desejo de ver a literatura representando o mundo em que vivemos" (CANDIDO, 2002, p. 221), em especial, o Mundo das Mulheres! 


\subsection{O MOLDE: DE MULHER PARA MULHER, A REPETIÇÃO NA DIFERENÇA PELA LIBERDADE}

Geração após geração, se reconhece o nome da princesa Scherezade como uma das mais ardilosas contadoras de histórias que, com as artimanhas da palavra, se projeta no universo feminino para romper uma série de preconceitos e estereótipos advindos do mundo patriarcal.

Apesar de a personagem ser consciente do estado de dependência e submissão a que a ideologia dominante relegou a mulher durante anos, ela torna-se o molde, o protótipo ativo da mulher atual que vai se revelando aos poucos, em busca da sua própria identidade, autonomia e liberdade.

A Scherezade piñoniana é a única mulher corajosa e decidida, capaz de lutar contra o ciclo de matanças que vêm exterminando todas as jovens do reino, conforme já fora mencionado nos capítulos anteriores e, portanto, não há a necessidade de retomar os pormenores da história.

Aliás, o intuito é fazer com que transpareça a ruptura dessa tradição, a partir do momento em que ela deixara para trás seu pai, sua casa, parentes e amigos, bem como uma série de princípios, para vivenciar uma outra realidade repleta de sonhos, ilusões e fantasia junto a Fátima que a criara com amor e carinho.

Desta maneira, a personagem abriga em si mesma o desejo e o sonho de inúmeras mulheres em ter uma posição de prestígio, de se tornar esposa de um homem bem-sucedido, de ter a mesma vocação para contar histórias, fabricando ilusões e fantasias, de conseguir encontrar o príncipe encantado, rever amigos e poder "gozar", acima de tudo, de um bem supremo, a liberdade.

Nesta concepção, Bachelard (1988) diz que o sonho é algo imprescindível para que o homem se abra para uma nova vida; é no sonho ou no devaneio que o mundo surge pela imaginação.

Considerando este pensamento, denota-se que as personagens femininas piñonianas se fundem, se complementam e tendem a eternizar-se como as sequências das histórias, ou melhor, a Scherezade que herdara o dom de narrar da mãe se 
perpetua nesta figura já falecida que, posteriormente, se perpetua na ama de criação Fátima que, apesar de ausente, era exímia contadora de histórias. Dessa forma, Scherezade vivia repetindo situações e gestos, inspirada no modo de ser dessa mulher que tanto Ihe ensinara. $E$ tais ensinamentos acabaram sendo passados adiante, mesmo sem que houvesse esta intenção, para a irmã Dinazarda. Agora Scherezade, com exclusividade na arte de narrar, exerce seu ofício de contadora de histórias fantásticas e maravilhosas que aguçam a curiosidade do leitor ao salvaguardar "juntos" a próxima noite, numa espécie de circulo interminável de expectativas e forças renovadas.

Neste ponto, verifica-se que o discurso feminista se concretiza por meio do envolvimento do leitor, que se vê na posição de testemunha das ações da personagem, reconhecendo os objetivos implícitos destas ações, dada a situação insustentável em que será efetuado o rompimento das imposições sociais que almejam tirá-la de cena, ou seja, aniquilá-la.

Verifica-se a inserção de sua irmã, Dinazarda, que, de tanto ouvir as histórias contadas por Scherezade, desejava aprendê-las e contá-las para poder substituí-la nos momentos difíceis e de sua ausência. E se, porventura, esse fato não acontecesse, a inveja corroiria não somente sua alma, mas, também, todo seu corpo por não ter a chance de copular com alguém que já Ihe atiçava os hormônios, fazendo-a quase subir de gozo pelas paredes só de imaginar tal situação. Nota-se que o sonho e a conduta de Dinazarda podem ser identificados como um prolongamento do protótipo de Scherezade e uma estratagema para enlear eternamente o Califa no universo feminino, pois [...] Mal despedira-se de Dinazarda e Jasmine, apressadas as duas em tomar seu lugar, receosas de a fuga ser descoberta antes do tempo previsto. (PIÑON, 2006, p. 350)

Nesse jogo de "passa e repassa" feminino, ainda resta mencionar a figura de Jasmine, que estabelece o elo de ligação entre as duas irmãs, na medida em que busca pequenas sutilezas fora do ambiente palaciano para fortificar o império que Scherezade erguera com o poder da palavra. Desta maneira, Jasmine tornar-se-á a mais recente seguidora e/ou propagadora do discurso. 
Com quem contaria na batalha derradeira? Pensa seriamente em Jasmine. [...] Mas não quisera sempre imitar Scherezade? Tanto que, pelas manhãs, extraía-lhe o cheiro e o talento ao mesmo tempo, sem perder de vista a distração estampada no rosto da contadora. (PIÑON, 2006, p. 313)

À véspera da fuga, multiplicando-se em funções, Jasmine incorporara a imagem de Scherezade ao seu corpo. Estava certa de que o Califa brevemente se esqueceria da contadora de histórias. Também Dinazarda, sobra viva de um trio às vésperas de dissolver-se... (PIÑON, 2006, p. 350)

O processo de repetição de mulher para mulher até aqui referenciado nos remete à possibilidade de que a arte de narrar e/ou contar histórias por intermédio das contadoras "talvez" esteja em vias de extinção. Todavia, essa tríade feminina consegue perpetuar o dom da contação de histórias impulsionado por mitos, lendas, personagens, heróis, objetos tanto lembrados, inventados quanto retirados da própria realidade cotidiana, pois a escrita sequer é considerada para a realidade e para as histórias inventadas. Todo conhecimento deriva da oralidade e credibilidade: "[...] As regras da vida não estão escritas. Cabe-Ihe inventá-las a cada aurora” (PIÑON, 2006, p. 255).

Nessa concepção, Michel Foucault (2006, p. 56) relaciona o poder e a verdade ao discurso, visto que alerta sobre a intenção que há por trás de todo discurso: "o discurso não é simplesmente aquilo que traduz as lutas ou os sistemas de dominação, mas aquilo por que, pelo que se luta, o poder do qual nos queremos apoderar".

É importante enfatizar que essa visão de mulher para mulher não deve ser entendida como uma mera reprodução ou cópia, mas como o outro que vive em si mesmo e que também possa divergir do outro. Então, percebe-se que a repetição não é mantida somente por intermédio das palavras proferidas, mas também por meio das ações e transposições de corpos para a concretização das práticas sexuais com o poderoso Califa.

Djauara preocupa-se em apagar o seu corpo para fazer surgir nela a figura de Scherezade, que confiara, desde o início, na eficácia daquele plano. [...] ainda que ostentasse experiência sexual, havendo cedo aprendido a dar prazer ao homem, fora-Ihe proibido demonstrar ao Califa 
sua sagacidade, em vivo contraste com Scherezade, inexperiente no assunto. (PIÑON, 2006, p. 322-323)

A isto deve acrescer que não importa se estes corpos são desprezados, amados, maltratados, submissos, invisíveis ou até mesmo dóceis, pois, na verdade, são investidos por relações de poder e de dominação que acabam por caracterizar-se em uma relação hierarquizada entre gêneros. E, diante disso, não há como não olhar o mundo segundo os binarismos criados a partir do masculino/feminino, pois Scherezade "empresta a cada papel uma imprescindível compreensão. Como homem e mulher, ri, chora, vítima de um trampolim emocional" (PIÑON, 2006, p. 131).

A esse respeito, os estudos feministas apontam teorias críticas que veem no masculino e feminino forças criadoras na composição de personagens. Por isso, Jung tornou-se interessante para as mulheres, por afirmar que o indivíduo atinge a completude ao ser capaz de incorporar aspectos do sexo oposto, em que o animus (masculino) complementa o feminino e a anima (feminina) o masculino.

Neste sentido, a personagem Scherezade pode ser encaminhada para uma vivência andrógina a partir do momento em que masculino e feminino convivem na mesma pessoa pela recriação de personagens: [...] E, de tanto abarcar seus mitos mais caros, obter uma recompensa a capacidade de disfarçar-se de homem e mulher indiscriminadamente, e interpretá-los com rara paciência. (PIÑON, 2006, p. 170)

A androginia, comum em muitas culturas, buscava a promoção da longevidade, da saúde, da juventude e o vigor. Ela era vivificada por grande parte dos deuses gregos e orientais, principalmente pelas divindades da vegetação e da fertilidade, como Dionísio, Cibele, Átis e Adônis. Essa vivência primitiva se justifica pelo fato de que se acreditava que não se poderia ser excelente em algo sem se tornar, ao mesmo tempo, o seu oposto. Então, essa junção de opostos justifica o comportamento, a experiência física e psíquica de Scherezade, um ser humano que está acima das diferenças de sexo, uma vez que esclarece o papel que as mulheres assumem na reconstrução da cultura, da sociedade. A esse respeito, observa-se outro nítido exemplo: [...] Assume [Scherezade] ao mesmo tempo a condição masculina e feminina com o intuito de compreender a dimensão de seres imortais. [...] (PIÑON, 2006, p. 222) 
É preciso acrescentar que esta personagem ainda pode ser revestida por uma espécie de teogonia, uma heroína com características imortais, de divindade, uma vez que já fora associada, no terceiro capítulo, à Grande Deusa. Pode-se dizer que essa teogonia não é a negação do princípio feminino, mas a sua convivência com o masculino. Temos, então, um ser que consiste na adição de uma unidade-totalidade.

Scherezade assume alternadamente papéis femininos e masculinos. Sente-se à vontade em descrever o falo e a vulva. As genitálias dos seres não a incomodam. Seu corpo absorve em igual intensidade as proporções de cada qual. Lateja, pulsa, incha, cresce, endurece, segundo a anatomia que representa seus relatos. Quando se cansa de ser homem, esquecida do que é ser mulher na corte de Bagdá, sente desprezo por uma humanidade imersa na sujeira e nas falsas ilusões. (PIÑON, 2006, p. 307)

A pós-modernidade trouxe consigo o movimento de aproximação de mundos, no qual consta, cada vez mais, a presença de mulheres no território do masculino. Portanto, conseguir-se-á abstrair não a insistência da desconstrução, mas a da superação da identidade sexual: o elogio da diferença também pautado pela questão de gênero. Assim, o termo "gênero" pode ser usado para tratar das diferenças entre homens e mulheres (designação gramatical definida por masculino e feminino) que passaram a fazer referência às distinções dentro de um mesmo sexo e, inclusive, entre outros sexos, cuja mudança de significado tornou-se indicativa do significado

[...] social, cultural e psicológico imposto sobre a identidade sexual biológica. É diferente de sexo (entendida como identidade biológica: macho/fêmea) e é diferente de sexualidade (entendida como a totalidade de orientação, preferência ou comportamento sexual de uma pessoa). (FUNCK, 1999, p. 20)

Apesar de a personagem vivenciar esse momento de impasse ou, talvez, de indefinição, abre-se um leque de oportunidade para a mulher escolher aquilo que melhor the convém sob a ótica de quem sabe o que é e o que quer. Ademais, tem-se a 
opção de livre escolha para transitar e perfazer a travessia de visibilidade, igualdade e identidade, revelando até um possível equilíbrio entre os sexos (androginia) nesse novo horizonte de expectativas capaz de gerar uma outra realidade, reforçada pelo vínculo entre mulheres.

$\mathrm{Na}$ verdade, são mulheres que não se envergonham de se expor ao público e desafiarem seu próprio destino. Mulheres livres para agirem e subverterem os valores arraigados e que regem a vida cotidiana, pois assumem a responsabilidade de definirem o seu papel com presteza e eficácia.

A esse respeito, Oliveira (1999) afirma que se trata de uma

experiência que não é feita de superposição de experiências femininas e masculinas, mas de uma gama infinita, na sua variedade, de mistura desses elementos, segundo o tempo de cada uma. Em outros termos, a liberdade. (OLIVEIRA, 1999, p. 130)

Essa realidade vivenciada e desejada por Scherezade é denominada zona selvagem, conforme explica Elaine Showalter (1994):

[...] Espacialmente ela significa uma área só das mulheres, um lugar proibido para os homens, [...] Experimentalmente, significa os aspectos do estilo de vida feminino que estão ao lado de fora e diferenciam-se daquele dos homens; [...] Mas, se pensarmos na zona selvagem metafisicamente, ou em termos de consciência, não há espaço masculino correspondente, já que tudo na consciência masculina está dentro do círculo da estrutura dominante e, desta forma, acessível à linguagem ou estruturada por ela. (SHOWALTER, 1994, p. 48)

Sendo assim, é possível afirmar que Scherezade atinge o auge de sua zona selvagem no momento em que se liberta das amarras dos papéis sociais e patriarcais e encontra a tão almejada independência, em um espaço que só a ela pertence: o da liberdade - felicidade. 


\subsection{O FEMININO TRANSGRESSOR EM NELIDA PIÑON}

Em pleno século $\mathrm{XXI}$, os estudos feministas ganham notoriedade nas diversas áreas do conhecimento. Assim, a reflexão sobre as questões de mulheres revela um ponto instigante, que causa certa inquietação em grupos sociopolíticos, históricos e culturais, por conceber o feminino como alvo de inúmeras (in)diferenças.

A partir desse aspecto, nota-se que os estudos sobre a mulher e a literatura passam a oferecer um meio privilegiado para entender as raízes dessas complexas indagações da sociedade contemporânea.

Os estudos de Simone Beauvoir (1967) sobre a construção do sujeito feminino mostram que as mulheres estão rompendo consigo mesmas, assumindo uma postura mais ativa e transgressora em relação ao seu papel social. Pode-se dizer que a construção da personagem Scherezade piñoniana figura entre essas duas vertentes, pontuadas na opressão e transgressão. Desta maneira, a feminilidade não está mais condicionada a um destino que Ihe rouba o direito de ser livre, determinando o seu papel na sociedade, simplesmente, como mãe e procriadora, que vive em função do filho, marido e casa, sem poder respirar, ou seja, asfixiada e confinada neste ambiente opressor. Assim, a mulher rompe com esse paradigma, vislumbrando novos olhares e perspectivas para além dos muros do patriarcalismo dominante.

É válido observar que esse desejo de ver-se em uma condição mais livre fez com que a escrita feminina ganhasse notoriedade, saindo da zona de silêncio ou de isolamento para desembocar no processo literário, o da criação.

Essa consciência sobre a condição da situação da mulher tornou-se um dos temas da escritura feminina, assumindo um caráter de denúncia, ao fazer com que a mulher passasse a liderar as situações, a ser dona do seu próprio destino e a expor explicitamente o seu desejo de não se sentir "frágil" ou inferior, como um segundo sexo que se encontra à margem da sociedade.

Neste âmbito, a escritora Virgínia Woolf, no seu clássico ensaio sobre a condição da mulher escritora, já apontava a importância de um espaço reservado, em que a mulher tenha autonomia sobre suas reflexões, de maneira que essas possam costurar 
as bases da escritura, pois "a ficção é como uma teia de aranha, muito levemente presa à vida pelos quatro cantos". Mas observava que esse espaço ia tornando-se cada vez mais escasso diante da necessidade de existir em relação ao outro ou a partir dele, característica que vai tolher a expansão ficcional do feminino, conforme indagação da escritora: "quem pode medir o fogo e a violência do coração do poeta quando capturado e enredado num corpo de mulher?" (WOOLF, 1985, p. 64).

É neste contexto de transformação e interiorização que a escritora Nélida Piñon constrói as personagens femininas, em especial, Scherezade, na busca incessante de fugir dessa realidade que as circunda, com o intuito de transgredirem o peso das amarras patriarcais dominantes vivenciadas no dia a dia, para transformá-las em sujeitos da história sob o sol tropical da liberdade.

Apesar de as mulheres nelidianas obedecerem a leis especificas impostas pelo califado, elas as transgridem e revelam capacidade lógica de determinar as novas regras desse jogo de poder, fomentadas por mudanças plausíveis no contexto no qual estão inseridas.

O exercício de transgressão permite articular a passagem entre singular e coletivo, uma vez que estamos situados na junção entre realidade pessoal e realidade social. Ademais, a transgressão nos mostra um universo que flui sem limites, concentrando as forças incríveis, sagradas e perigosas em nós mesmos.

Cabe lembrar que isso só é possível por meio de uma linguagem significativa, em que se possa evidenciar o ser no mundo, pois quem fala se coloca na posição de sujeito, de agente, de dominador, que é exatamente a postura de Scherezade na narrativa. Então, esse posicionamento vai ao encontro do pensamento de Judith Butler (2003, p. 18-19), para quem o "sujeito do Feminino é em si uma formação discursiva", isto é, não basta ter a biologia do sexo feminino para ser uma mulher e, com isso, assumir um gênero, porque enquanto "o sexo é um atributo biológico, o gênero é culturalmente construído" (BUTLER, 2003, p. 24).

Desta maneira, a questão da identidade feminina é repensada não somente no romance, mas no bojo das representações literárias, pois a Scherezade nelidiana tornase a guardiã da palavra, da tradição da narrativa, bem como o protótipo do ser feminino, da liberdade. Eis o surgimento de uma nova consciência de mulher associado ao 
posicionamento de Sartre (2005, p. 122): "o ser da consciência é um ser para o qual, em seu ser, está em questão o seu próprio ser". Então, conclui-se que o ser da consciência é aquele que, além de adotar uma postura subversiva diante da vida, inquieta-se e liberta-se do cerco das obrigações sociais e pessoais.

Portanto, pode-se dizer que Nélida Piñon construiu Scherezade como o legítimo ser da consciência, a mulher de todos os tempos, uma identidade avassaladora que percorre as trilhas do feminismo para romper com os estereótipos estabelecidos por uma sociedade arcaica, patriarcal e com o discurso vigente dominante para estimular, sobretudo, a literatura de escritura feminina. 
Quando a atividade dos escritores de um certo período se integra num sistema articulado de obras e essas obras se ligam por denominadores comuns que permitem reconhecer as notas dominantes de uma fase, ocorre a formação da continuidade literária. 
O presente trabalho percorreu as veredas da literatura de autoria feminina, buscando analisar a personagem Scherezade no romance Vozes do deserto. Vimos que Nélida Piñon concedeu um tratamento pessoal e literário ao tema, utilizando As mil e uma noites como repertório tradicional, cíclico e inovador para vislumbrar, por meio da mais audaz heroína, contadora de histórias, a mulher de todos os tempos.

Piñon cria uma outra história sob olhares e perspectivas de mulheres, em especial, de mulheres transgressoras que são sujeitos da própria história, donas do destino, donas das palavras que pronunciam ao retratarem suas experiências, desejos, emoções e sentimentos para o mundo exterior, subvertendo a ordem patriarcal e, ao mesmo tempo, provando que, como uma pedra de toque, o destino de uma mulher pode ser outro. Assim, as mulheres tornaram-se "a menina dos olhos", ou seja, o referencial das teorias contemporâneas e não são mais vistas como frágeis, submissas, ou, ainda, mero "suportes" para ancorar o peso do mundo dos homens. Desta maneira, o termo transgressão abordado neste corpus de pesquisa permite ser aludido a um cruzar fronteiras, entrar em um território novo, o da diferença.

Então, pode-se dizer que é a partir dessa personagem vertida do ramo sírio, ou ainda, da história "moldura", que se arma a elaboração de todo o romance, pois a maior ênfase está em visualizar, de uma forma mais aprofundada, a mulher em si, uma vez que está configurada em primeiro plano. Portanto, as histórias contadas por ela já não despertam tanto interesse e se instituem em um outro nível camuflado na tessitura textual. Por isso, nota-se uma polifonia de vozes narrativas que ajudaram a compor a sua construção na narrativa.

Convém salientar que as vozes são ressaltadas já desde o título Vozes do deserto, vozes que clamam pelo silêncio manifestado por toda uma geração de mulheres. Vozes oprimidas, injustiçadas e insatisfeitas com esse espaço infértil para firmar-se e tornar-se mulheres. Vozes que, apesar do espaço, tempo e ventos, afirmamse e se tornam um marco de resistência que não poderá ser calado, menosprezado, negligenciado e ignorado pelo mundo.

Neste âmbito, o intuito de realizar uma análise com base na perspectiva da crítica feminista permitiu abordar, desde o início, a situação da escritora Nélida Piñon na cultura brasileira contemporânea, explicitando aspectos de sua vida e obra que a 
consagraram como a escritora intelectual no século XXI. Pode-se dizer que, para além do mundo da imaginação e fantasia, interpõe-se a arte da criação literária sob a estética da experiência humana, configurando as repercussões e críticas que giram em torno de si e, consequentemente, a significação de Vozes do deserto, no universo literário.

No que diz respeito à perpetuação de um mito: da Scherezade oriental até a Scherezade brasileira, foi possível refletir e perfazer uma viagem no túnel do tempo para rever o passado da arte milenar de contar histórias, por intermédio das contadoras que trouxeram à lume histórias para abrilhantar a cultura brasileira. Além disso, vivenciar o eterno retorno de As mil e uma noites permitiu retomar uma das personagens mais conhecidas e míticas da literatura universal chamada Sahrazad, no que concerne às versões e recriações abordadas na história. Analisando essa trajetória, chegamos à representação de Scherezade em Vozes do deserto, como o protótipo de mulher resoluta mais ativo e significativo que se poderia vislumbrar de todos os tempos na ficção brasileira.

Quanto ao entrelaçamento de poder, erotismo e feminismo, perscrutamos a construção das personagens femininas, em especial, Scherezade, na narrativa. Então, tecemos uma revisão sobre a crítica feminista com o intuito de contestar o sistema patriarcal dominante, investigando a literatura produzida por mulheres sob diversos aspectos como a história, os estilos, os temas, os gêneros e as estruturas dos escritos de mulheres, a psicodinâmica da criatividade feminina, a trajetória da carreira individual ou coletiva e a evolução e as leis de uma tradição literárias de mulheres (SHOWALTER, 1994, p. 12). A partir daí, estabelecemos uma articulação do feminismo ao pósmodernismo para, posteriormente, analisar a personagem sob o jugo do poder, erotismo e feminismo. E, para contemplar essa visão projetiva da cultura contemporânea, inserimos a representação de Scherezade no arquétipo da Grande Mãe e Penélope.

É, portanto, como literata que Nélida expõe com primazia perfis femininos, revelando assim, o mundo das mulheres. Pode-se dizer que é um território onde tudo acontece ao mesmo tempo, agora. Mas, faz emergir mulheres que têm "vez e voz" e, com certeza, estão cada vez mais livres das amarras patriarcais dominantes. Nesse sentido, vislumbrar-se-á o poder da palavra configurado nas vozes do romance, em 
especial, na voz de Scherezade que foi capaz de imprimir à narração, inovações necessárias para refletir o mundo e a luta das mulheres contra as intempéries da vida cotidiana.

Cabe lembrar que são mulheres em transgressão que almejam uma maior visibilidade de voz e espaço, pois se arriscaram para revelar seus sentimentos, suas emoções, suas experiências, enfim, sua condição de ser e estar no mundo. Firmaramse como mulheres, sujeito da própria história e fizeram a diferença na história. E, em um certo sentido, ao retratá-las segundo a ótica da crítica feminista, Nélida Piñon, propositalmente ou não, permitiu ao leitor resgatar as características de cada uma das fases da narrativa de autoria feminina, de acordo com a classificação de Elaine Showalter, discutida no terceiro e quarto capítulo: a fase feminina, a feminista e a fêmea.

Neste âmbito, pode-se dizer que Scherezade torna-se o molde, o ícone ou, até mesmo, o protótipo ativo capaz de configurar as mulheres de todos os tempos, pois ousou assumir-se como "diferente" para afirmar a alteridade da mulher, abrindo espaço para as indagações sobre si mesma, sobre sua condição e papel na história, sobre o outro e, inclusive, sobre o mundo que a circunda.

Com certeza, é incorporado a esta personagem o feminismo transgressor, na medida em que rompe com uma série de estereótipos e preconceitos para se inscrever em um patamar superior, pois estamos diante da mulher da fase fêmea de que trata Showalter cuja visibilidade possibilita o reconhecimento da mulher na linha evolutiva do tempo.

Portanto, a inovação do romance está no modo como este se propõe a refletir sobre a temática feminina, ou seja, a mulher exprimindo uma subversão de valores, saberes e poderes, os quais são questionados e denunciados aos longo dos anos e, ao mesmo tempo, ressaltados pela tríade que é e sempre foi essencial para a literatura: autor, obra e leitor.

Assim, diante de todo o arcabouço analisado envolvendo a temática feminina em consonância com a bordagem dos vários teóricos (Bataille, Benjamin, Bourdier, Foucault, Hollanda, Hutcheon, Paz, Said, Showalter, Tacca, Xavier, Zolin entre outros), foi possível repensarmos a situação feminina livres das amarras patriarcais 
configuradas no tempo e espaço, retratando as experiências cotidianas da sociedade e indagações importantes e necessárias para uma melhor reflexão e compreensão não somente da obra em si, mas também do ser humano, do outro e do mundo, conforme foi comprovado nesta obra da escritora Nélida Piñon, com tamanha maestria. 


\section{REFERÊNCIAS BIBLIOGRÁFICAS}

ADORNO, Theodor Wiesengrund. Notas de Literatura I. Tradução Jorge M. B. de Almeida. São Paulo: Duas Cidades; Ed. 34, 2003. (coleção Espírito Crítico)

AGUIAR, Maria Alice. O eros da fala, o mito da criação e a identidade do feminino em Vozes do deserto de Nélida Piñon. Texto apresentado no Congresso da Associação Internacional Lusitanistas, Santiago de Compostela, 2005.

ALVES, Maria Angélica. Entre a sombra e a luz. In: Elódia Xavier. Tudo no feminino: a mulher na narrativa brasileira contemporânea. Rio de Janeiro: Editora Francisco Alves, 1991.

ANDRADE, Maria Luiza Oliveira. Mulher e memória em Vozes do Deserto, de Nélida Piñon. Trabalho apresentado no Seminário Internacional Mulher e Literatura (UESC), em setembro de 2007, Ilhéus.

ANÔNIMO. Livro das mil e uma noites. Volume I, ramo sírio. Introdução, notas, apêndice e tradução de Mamede Mustafá Jarouche. São Paulo: Globo, 2006.

ARISTÓTELES. Arte retórica e arte poética. Rio de Janeiro: Ediouro, s.d.

BACHELARD, Gaston. A poética do devaneio. Tradução Antônio de Pádua Danesi. São Paulo: Martins Fontes, 1988.

BAKHTIN, Michail. Marxismo e filosofia da linguagem. Tradução Michel Lahud e Yara Frateschi Vieira. São Paulo: Hucitec, 1988.

BALDERSTON, Daniel; GONZALEZ, Mike. Encyclopedia of Latin American and Caribbean Literature, 1900-2003. London; New York: Routledge, 2004. 
BATAILLE, Georges. O erotismo: o proibido e a transgressão. Tradução João Bernard da Costa. 2. ed. Lisboa: Moraes editores, 1980.

BATAILLE, Georges. O erotismo. Tradução de Claudia Fares. Porto Alegre: L\&PM, 1987.

BATAILLE, George. A literatura e o mal. Tradução Sueli Bastos. Porto Alegre: L\&PM, 1989.

BEAUVOIR, Simone de. O segundo sexo. Tradução Sergio Milliet. Rio de Janeiro: Nova Fronteira, 1967.

BENJAMIN, Walter. Magia e técnica, arte e política: ensaios sobre literatura e história da cultura. 7. ed. Tradução Sergio Paulo Rouanet. São Paulo: Brasiliense, 1994.

BENJAMIN, Walter. O narrador: considerações sobre a obra de Nikolai Leskoi. In:__ Obras Escolhidas. Tradução Sergio Paulo Rouanet. São Paulo: Brasiliense, 1987.

BIBLIA SAGRADA. Tradução Ivo Storniolo e Euclides Martins Balancin. Edição Pastoral. Sociedade Bíblica Católica Internacional e Edições Paulinas. São Paulo, 1990.

BONFIM, Maria C. de Mesquita. Depoimento da Acadêmica Nélida Piñon. Gravado na Sala dos Fundadores do Petit Trianon - Academia Brasileira de Letras em 08 de outubro de 1998. Transcrição: Tânia Lúcia Oliveira Barreto. Revisão: M. C. de M e Nélida Piñon. Fonte: http://virtualbooks.terra.com/osmelhoresautores/biografias/NelidaPinon.htm

BONNICl, Thomas. O pós-colonialismo e a literatura: estratégias de leitura. Maringá: Eduem, 2000. 
BOOTH, Wayne. A retórica da ficção. Tradução Maria Teresa H. Guerreiro. Lisboa: Arcádia, 1980.

BORGES, Jorge Luís. História da eternidade. In: Obras completas. Tradução Glauco Mattoso [et al.]. São Paulo: Globo, 1999, v. 4.

BORGES, Jorge Luís. Sete noites. Tradução João Silvério Trevisan. São Paulo: Max Limonad, 1983.

BOSI, Alfredo. Contra capa. Vozes do deserto. 5. ed. Rio de Janeiro: Editora Record, 2006.

BOSI, Ecléa. Memória e sociedade: lembrança de velhos. São Paulo: T.A. Queiroz: EDUSP, 1987.

BOURDIEU, Pierre. A dominação masculina. Tradução Maria Helena Kühner. Rio de Janeiro: Bertrand Brasil, 1999.

BOURDIEU, Pierre. O poder simbólico. Rio de Janeiro: Bertrand Brasil; Lisboa: DIFEL, 1989.

BROOKE-ROSE, Christine. Stories, Theories and Things. Cambridge: Cambridge University Press, 1992.

BRUNEL, Pierre. Dicionário de mitos literários. Tradução Carlos Sussekind. 2. ed. Rio de Janeiro: José Olympio, 1997.

BUTLER, Judith. Problemas de gênero: feminismo e subversão da identidade. Rio de Janeiro: Civilização Brasileira, 2003. 
CALVINO, Ítalo. Seis propostas para o próximo milênio. Tradução Ivo Barroso. São Paulo: Companhia das Letras, 1990.

CANDIDO, Antonio; ROSENFELD, Anatol; PRADO, Décio de Almeida; GOMES, Paulo Emílio Sales. A personagem de ficção. 3. ed. São Paulo: Perspectiva, 1972.

CANDIDO, Antonio. Literatura e sociedade: estudos de teoria literária. 8. ed. São Paulo: T. A. Queiroz, 2000.

CANDIDO, Antonio. Vanguarda: renovar ou permanecer. In: - Textos de intervenção. Seleção, apresentações e notas de Vinicius Dantas. São Paulo: Duas Cidades; Ed. 34, 2002. (Coleção Espírito Crítico)

CASTELLO Branco, Lúcia. O que é escrita feminina. 1. ed. São Paulo: Brasiliense, 1991.

CHEVALIER, Jean \& GHEERBRANT, Alain. Dicionário de símbolos: mitos, sonhos, costumes, gestos, formas, figuras, cores, números. Tradução Vera da Costa e Silva et. al. 17. ed. Rio de Janeiro: José Olympio, 2002.

CIRLOT, Juan-Eduardo. Dicionário de símbolos. Tradução Rubens Eduardo Ferreira Frias. São Paulo: Editora Moraes, 1984.

COELHO, Nelly Novaes. O conto de fadas: símbolos, mitos, arquétipos. São Paulo: Paulinas, 2008.

COELHO, Nelly Novaes. A literatura feminina no Brasil contemporâneo. São Paulo: Editora Siciliano, 1993.

COELHO, Gislene Teixeira. Vozes do deserto: uma refabulação das mil e uma noites. Revista Castilho. Universidade Federal de Juiz de Fora - UFJF. Ano I. vol. 2. nov., 2005. 
CORTÁZAR, Júlio. Do conto breve e seus arredores. In: Valise de Cronópio. 2.ed. Tradução Davi Arrigucci Jr e João Alexandre Barbosa. São Paulo: Perspectiva, 1974. (Coleção Debates)

COSTA, Flávio Moreira da. Treze dos melhores contos da mitologia. Rio de Janeiro: Ediouro, 2004.

COSTA, M.C. C. A milésima segunda noite: da narrativa mítica à telenovela. Análise estética e sociológica. São Paulo: Annablume/Fapesp, 2000.

DELEUZE, Gilles. Sacher-Masoch: o frio e o cruel. Tradução Jorge Bastos. Rio de Janeiro: Jorge Zahar Ed., 2009.

DIXON, Paul. Gênero sexual e os paradigmas narrativos de Nélida Piñon. Veredas Revista da Associação Internacional de Lusitanistas. Porto Alegre: EDIPUCRS, v. 5, p. 201-210, dez. 2002.

D’ONÓFRIO, Salvatore. Teoria do texto. São Paulo: Editora Ática, 2006.

DURAND, Gilbert. A imaginação simbólica. Tradução Carlos Aboim de Brito. Lisboa: Edições 70, 1995.

ELIADE, Mircea. O mito do eterno retorno: arquétipos e repetição. Tradução Manuela Torres. Lisboa: Edições 70, 1993.

ELIOT, T. S. Ensaios de doutrina crítica. Lisboa: Guimarães, 1962.

FONTES, Maria Helena Sansão. Mulher em Corpo de baile de Guimarães Rosa. In: Anais do $5^{\circ}$ Seminário Nacional Mulher e Literatura. Natal: UFRN: Ed. Universitária, 1995. 
FORSTER, Edward. M. Aspectos do romance. Tradução Maria Helena Martins. Porto Alegre: Editora Globo, 1969.

FOUCAULT, Michel. História da sexualidade: o uso dos prazeres. Vol II. Tradução Maria Thereza da Costa Albuquerque e J. A. Guilhon. 11. ed. Rio de Janeiro: Edições Graal, 1988.

FOUCAULT, Michel. A microfísica do poder. São Paulo: Graal, 2003.

FOUCAULT, Michel. A ordem do discurso. Tradução Laura Fraga de A. Sampaio. 14. ed. São Paulo: Loyola, 2006

FOUCAULT, Michel . O que é um autor? Lisboa: Vega, 2002.

FOUCAULT, Michel. Vigiar e Punir: nascimento da prisão. Tradução Raquel Ramalhete. 32. ed. Petrópolis: Editora Vozes, 1987.

FREYRE, Gilberto. Casa-grande \& senzala: formação da família brasileira sob o regime da economia patriarcal. 34. ed. Rio de Janeiro: Record, 1998.

FUNK, S. B. Da questão da mulher à questão do gênero. In: (Org.) Trocando idéias sobre a mulher e a literatura. Florianópolis: UFSC, 1999.

GALLAND, Antoine. As mil e uma noites. Tradução Alberto Diniz. 2. ed. Rio de Janeiro: Ediouro, 2000, 2v.

GANCHO, Cândida Vilares. Como analisar Narrativas. 7. ed. São Paulo: Ática, 2001.

GARSCHAGEN, Bruno. Nélida Piñon. Entrevista. (2007). Disponível em http://brunogarschagen.com/2007. Acesso em 30 de Junho de 2009 
GENETTE, Gérard. Palimpsestos: a literatura de segunda mão. Tradução L. Guimarães e M. A. Ramos Coutinho. Belo Horizonte: FALE/UFMG, 2006.

GOMES, Purificación Barcia. O método terapêutico de Scherazade: mil e uma histórias de loucura, de desejo e cura. São Paulo: lluminuras, 2000.

GOTLIB, Nádia Batella. A literatura feita por mulheres no Brasil. In: BRANDÃO, I., MUZART, Z. L. (Org.). Refazendo nós: ensaios sobre mulher e literatura. Florianópolis: Ed. Mulheres, Santa Cruz do Sul: EDUNISC, 2003.

HEIDEGGER, Martin. Heidegger. São Paulo: Nova Cultural, 2005.

HOLLANDA, Heloísa Buarque de. Tendências e impasses: o feminismo como crítica da cultura. Rio de Janeiro: Rocco, 1994.

HORTA, Maria Teresa. Xerazade a dona das palavras que pronuncia. Diário de Notícias, Portugal, Quarta-feira, Edição Papel, 15 de dezembro de 2004.

HUTCHEON, Linda. Poética do pós-modernismo: história, teoria, ficção. Tradução Jayme Salomão. Rio de Janeiro: Imago, 1991.

ISER, Wolfgang. A interação do texto com o leitor. In: LIMA, L. C. (Org.). A literatura e o leitor. textos de estética da recepção. Rio de Janeiro: Paz e Terra, 1979.

JAGGAR, Alison M. Feminist politics and human nature. United States of America: Rowman \& Allanheld Publishers, 1983.

JAROUCHE, Mamede Mustafa. Livro das mil e uma noites. Volume I, II, III - Ramo Sírio. 3. ed. São Paulo: Globo, 2006.

JUNG, Carl Gustav. Símbolos da transformação. 4. ed. Petrópolis: Vozes, 1999. 
LEMOS, Wagner. Nélida Piñon. Entrevista. 2005. Acesso em 10 de agosto de 2009. Disponível em: www.wagnerlemos.com.br/nelidapinon.htm>.

LISPECTOR, Clarice. De corpo inteiro. Rio de Janeiro: Editora Artenova, 1975.

LOURO, Guacira L. Gênero, sexualidade e educação: uma abordagem pósestruturalista. Petrópolis: Vozes, 1997.

MACEDO, Ana Gabriela; AMARAL, Ana Luisa (orgs.). Dicionário da crítica feminista. Porto: Afrontamento, 2005.

MACHADO DE ASSIS, Joaquim Maria. A nova geração. In: - Crítica literária. Rio de Janeiro: Jackson, 1975.

MEIRELLES, Cecília. Problemas da literatura infantil. 3. ed. Rio de Janeiro: Nova Fronteira, 1984.

MIGUEL, Mariana Correia Mourente. Vozes do deserto e o Livro das mil e uma noites: uma breve aproximação. Trabalho apresentado no Curso de extensão: A ficção multifacetada de Nélida Piñon, UFRJ, 2007.

MIGUEL, Mariana Correia Mourente. O caminho da não-violência. Acesso em 30 de junho de 2008. www.prodema.ufpb.br/revistaartemis/numero2/arquivos/artigos

MILLET, K. Sexual politics. New York: Doubleday \& Company, 1970.

MONIZ, Naomi. As viagens de Nélida, a escritora. Campinas, São Paulo: Editora da UNICAMP, 1993. Prêmio Melhor Livro de Ensaios do Ano pela APCA (Associação Paulista de Críticos de Arte). 
MONIZ, Naomi. Nélida Piñon: a questão da história em sua obra. In: SHARPE, Peggy (Org.). Entre resistir e identificar-se: para uma teoria da prática da narrativa brasileira de autoria feminina. Florianópolis: Editora Mulheres: Goiânia: CEGRAF, 1997.

MORIN, E. O paradigma perdido: a natureza humana. Tradução Hermano Neves. Lisboa: Europa-América, 1995.

NEUMANN, Erich. A Grande Mãe. Tradução F. Pedroza Mattos et al. São Paulo: Cultrix, 1996.

NUNES, Benedito. O mundo imaginário de Clarice Lispector. In: O dorso do tigre. 2. ed. São Paulo: Perspectiva, 1976.

OLIVEIRA, R. D. Elogio da diferença: o feminismo emergente. 3. ed. São Paulo: Brasiliense, 1999.

PADILHA, Tarcísio. Discurso de recepção de Nélida Piñon na Academia Brasileira de Letras/Filosofia. In: ANAIS da Academia de Letras. Ed. Eletrônica Maanaim Informática Ltda., janeiro a junho 2005.

PAZ, Octavio. A dupla chama, amor e erotismo. Tradução Wladyr Dupont. São Paulo, Siciliano, 1994.

PAZ, Octavio. Signos em rotação. Tradução Sebastião Uchoa Leite. São Paulo: Editora Perspectiva, 1972.

PAZ, Octavio. Convergências. Rio de Janeiro: Rocco, 1991.

PAZ, Octavio. O arco e a lira. Tradução Olga Savary. 2. ed. Rio de Janeiro: Nova Fronteira, 1982. 
PEREIRA JUNIOR, Luiz Costa. A paixão feminina pela palavra. Revista Língua Portuguesa. São Paulo, 2005. Disponível em http://revistalingua.uol.com.br/textos.asp> Acesso em 10 de agosto de 2009.

PIÑON, Nélida. Vozes do deserto. 5. ed. Rio de Janeiro: Editora Record, 2006.

PIÑON, Nélida. Prêmio Príncipe de Astúrias de Letras 2005. Discurso. In: Anais da Academia de Letras. Rio de Janeiro: jan. a junho 2005. Disponível em: www.nelidapinon.com.br> Acesso em 10 agosto de 2009.

PONTIERO, Giovanni. Notes on the fiction of Nélida Piñon. Review 76 19, Inverno, 1976, p. 67-71.

QUEIROZ, V. Crítica literária e estratégias de gênero. Niterói: EDUFF, 1997.

ROSA, Lucia Regina Lucas. Contadores de histórias em A república dos sonhos e em Vozes do deserto, de Nélida Piñon. Revista eletrônica da crítica e teoria de literaturas. DOSSIÊ: literatura, oralidade e memória. PPG, Letras/UFRGS - Porto Alegre, vol. 4, № $01-$ jan/jun, 2008.

REGO, José Lins do. Menino de engenho. 50. ed. Rio de Janeiro: José Olympio, 1991.

REGO, José Lins do. Histórias da velha Totônia. 5. ed. Rio de Janeiro: José Olympio 1981.

REIS, Carine Isabel. A magia da narrativa: uma leitura de Vozes do deserto, de Nélida Piñon. 2008. Dissertação (Mestrado em Leitura e Cognição) - Universidade de Santa Cruz do Sul - UNISC, Santa Cruz do Sul, 2008.

ROBERT, Marthe. Roman des origines et origines du roman. Paris: Gallimard, 1981. 
ROBLES, Martha. Mulheres, mitos e deusas: o feminino através dos tempos. Tradução William Lagos e Débora Dutra Vieira. São Paulo: Ed. Aleph, 2008.

ROMERO, Sylvio. Historia da literatura brasileira. 4. ed. Rio de Janeiro, 1985.

ROSENFELD, Anatol. Reflexões sobre o romance moderno. In: Texto/Contexto. 4. ed. São Paulo: Perspectiva, 1985.

ROWE, William \& SCHELLING, Vivian. Memory and modernity: Popular Culture in Latin America. Londres: Verso, 1991.

SAID, Edward. Representações do intelectual: as palestras de Reith de 1993. Lisboa: Edições Colibri, 2000.

SAID, Edward. Orientalismo: o oriente como invenção do ocidente. Tradução Tomás Rosa Bueno. São Paulo: Companhia das Letras, 2001.

SANTIAGO, Silviano. Nas malhas da letra. São Paulo: Companhia das letras, 1989.

SARLO, Beatriz. Cenas da vida pós-moderna. Rio de Janeiro: Ed. UFRJ, 1997.

SARTRE, Jean Paul. Em defesa dos intelectuais. São Paulo: Ática, 1994.

SARTRE, Jean Paul. O ser e o nada: ensaio de ontologia fenomenológica. Petrópolis: Vozes, 2005

SCHMIDT, Rita Terezinha. Os estudos sobre mulher e literatura no Brasil: percursos e percalços. In: DUARTE, Constância Lima. (Org.). Anais do V Seminário Nacional Mulher e Literatura. Natal: EDUFRN, 1995. (p.175-187) 
SEVCENKO, Nicolau. O Orfeu extático na metrópole: São Paulo, sociedade e cultura nos frementes anos 20. São Paulo: Companhia das Letras, 1992.

SHOWALTER, Elaine. A crítica feminista no território selvagem. Trad. Deise Amaral. In: HOLLANDA, H. B. (Org.). Tendências e impasses: o feminismo como crítica da cultura Rio de Janeiro: Rocco, 1994.

SHOWALTER, Elaine. A literature of their own: british women novelists from Brontë to Lessing. New Jersey: Princeton UP, 1985.

SHOWALTER. Elaine. The female malady: women, madness and English culture 18301980. London: Virago, 1985.

SILVEIRA, Nise da. Vida e obra de Jung. 9. ed. Rio de Janeiro: Paz e Terra, 1981.

SIGÜENZA, Carmen. Nélida Piñon diz que "as palavras erotizam a realidade". Folha On Line, out. 2005. Disponível em: http://www1.folha.uol.com.br/folha/ilustrada/ult90u54426.shtml> Acesso em: 10 dez. 2008.

SNEED, Paul. M. An interview as part of Nelida Piñon's visit to the University of Oklahoma, 2005.

STEEN, van Edla. Viver \& escrever. Porto Alegre: L\&PM; Brasília: INL, 1982.

SWAIN, Tânia Navarro. Você disse imaginário? In: (Org.). Histórias no plural. Brasília: EDUNB, 1994.

TACCA, Oscar. As vozes do romance. Tradução Margarida Coutinho Gouveia. Coimbra: Livraria Almedina, 1983.

TAHAN, Malba. As mil e uma noites. Rio de Janeiro: Ediouro, 2001. v. 1 e 2. 
TATTAR, Maria (Org.). Contos de fadas. Edição comentada \& ilustrada. Rio de Janeiro: Jorge Zahar Editor, 2004.

TEIXEIRA, Vera Regina. Texto, contexto e pretexto na obra de Nélida Piñon. Letras de hoje. Porto Alegre, v.30, № 1, mar. 1995, p. 109-117.

TOURAINE, Alain. O mundo das mulheres. Tradução Francisco Moras. Petrópolis, Rio de Janeiro: Vozes, 2007.

VIANA, L. H. Por uma tradição do feminino na literatura brasileira. In: Seminário Nacional Mulher e Literatura, 5, 1993. Natal. Anais... Natal: UFRN, Universitária, 1995, p. $168-174$.

VILLARINO PRADO, M. Carmen. Entre a via-crucis e o prazer: representação da mulher transgressora na prosa brasileira recente (de autoria feminina). In: TOSCANO, Ana Maria da Costa, GODSLAND, Shelley (Orgs.). Mulheres más: percepção e representação da mulher transgressora no mundo luso-hispânico. Porto: Universidade Fernando Pessoa, 2004.

WAJNBERG, Daisy. Jardim de arabescos: uma leitura das Mil e uma noites. Rio de Janeiro: Imago, 1997.

WARNER, Marina. Da fera à loira: sobre contos de fadas e seus narradores. São Paulo: Companhia das Letras, 1999.

WOOLF, V. Um teto todo seu. Tradução Vera Ribeiro. 2. ed. Rio de Janeiro: Nova Fronteira, 1985.

ZIPES, Jack. When dreams came true: classical fairy tales and their tradition. 2. ed. New York: Routledge, 2007. 
ZOLIN, L. O. Crítica feminista e literatura de autoria feminina. In: BONNICI, T.; ZOLIN, L.O. (Org.). Teoria Literária: abordagens históricas e tendências contemporâneas. Maringá: Eduem, 2003, cap. 10 e 18, p. 161-182, 253-260.

ZOLIN, Lucia Osana. CASAGRANDE, Sarah. A representação da mulher no conto "Colheita", de Nélida Piñon: mulher emancipada. Programa de Pós-graduação em Letras, Universidade Estadual de Maringá, v. 29, n. 1, p. 15-22, 2007.

ZOLIN, Lucia Osana. VILLIBOR, Roberta F. Literatura de autoria feminina e reescrita: a Scherezade de Nélida Piñon. In: Projeto de Pesquisa: "Literatura de autoria feminina: identidade e diferença" - Universidade Estadual de Maringá (UEM). Maringá, 2008.

ZOLIN, Lúcia Ozana; VILLIBOR, Roberta Fresneda. Literatura de autoria feminina e

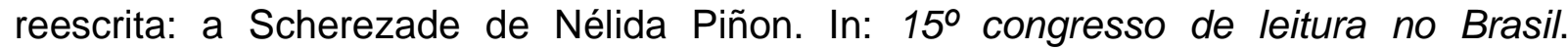
UNICAMP: ABL; Faculdade de Educação, 2005. p. 61-61.

ZOLIN, Lucia Osana. Desconstruindo a opressão: a imagem feminina em $A$ república dos sonhos, de Nélida Piñon. Maringá: Eduem - Editora da Universidade de Maringá, Paraná, 2003. 


\section{ANEXOS}




\section{ANEXO 1 - Lista de obras críticas sobre o trabalho de Nélida Piñon}

\section{BIBLIOGRAFIA SOBRE NÉLIDA PIÑON \\ (Livros, capítulos de livros, teses e dissertações, artigos em periódicos)}

AGUIAR, Maria Alice. O mito da origem na tríplice construção de Nélida Piñon: arcaica, medieval, moderna. 1994. Tese (Doutorado em Letras) - Universidade Federal do Rio de Janeiro, UFRJ, Rio de Janeiro,1994.

. O re-cultivo da Tera Galega pólo Resgate das Orixes em Finisterre, de Nélida Piñon. In: II Xornadas UFF de Cultura Galega, 1995, Niterói. Actas da II Xornadas UFF de Cultura Galega Universidade Federal Fluminense, Núcleo de Estúdios Galegos. Galícia: Xunta de Galícia, 1995. v. 1, p.12-12.

. Nélida Piñon: fundação em tempo tríplice. In: NUÑEZ, Carlinda Fragale Patê (Ed.) Letras em tese: poesia, teatro, narrativa. Rio de Janeiro: Relume Dumará e Centro Cultural do Banco do Brasil, 1995, v. 1, p. 63-69.

Ana: um novo mundo pela insurreição ao modelo: uma leitura da personagem feminina de Madeira Feita de Cruz, de Nélida Piñon. In: Letras em tese - Nélida Piñon: Fundação em tempo tríplice. Rio de Janeiro: Relume Dumara e CCBB, 1995. (enviado pela autora)

. Fundador no tríplice território da utopia. Paradoxa projetivas múltiplas em educação. São Gonçalo, v. IV, p. 65-69, 1996.

. Guia-mapa de Gabriel Arcanjo: o marco geográfico-existencial da obra de Nélida Piñon: 35 anos de produção literária. Caderno Seminal, v. 4. Rio de Janeiro, 1997. 
As peregrinações e a experiência do sagrado em Os selvagens da terra de Nélida Piñon. In: MALEVAL, Maria do Amparo Tavares (Org.) Estudos Galegos. Rio de Janeiro: EDUERJ - EDUFF, 1998, v. II, p. 117-131.

. Rastreando a categoria do mito e do sagrado em O pão de cada dia, de Nélida Piñon. In: II Congresso Nacional de Linguística e Filologia, 1998, Rio de Janeiro. II Congresso Nacional de Lingüística e Filologia A Linguagem e o Texto: Interações, Rio de Janeiro: Circulo Fluminense de Estudos Filológicos e Lingüísticos - UFR, v. 1. p. 44v-44v, 1998.

. Sob o tríplice signo de dédalo: o sagrado labirinto da terra, da cidade, da casa em Fundador de Nélida Piñon. Texto Apresentado no Congresso da Associação Internacional de Lusitanistas, Rio de Janeiro, 1999. (enviado pela autora)

. Em tempo de anunciação: Guia-mapa de Gabriel Arcanjo, um marco geográfico existencial na obra de Nélida Piñon. Revista Eletrônica Linguagem e Ensino, Pelotas: Editora Hipertexto, 2000, p. 89-104

O mito, a mulher e o sagrado em Os selvagens da terra de Nélida Piñon. Revista Eletrônica Linguagem e Ensino, Pelotas: Editora Hipertexto, p. 305-325, 2000.

A urdidura do mito e do sagrado em $O$ pão de cada dia. Paradoxa Projetivas Múltiplas em Educação, Brasil, v. 09, p. 05-10, 2001.

A construção medieva dos personagens hierofantes em Fundador de Nélida Piñon. In: III Encontro Internacional de Estudos Medievais da ABREM, 2001, Rio de Janeiro. Atas III Encontro Internacional de Estudos Medievais da ABREM. Rio de Janeiro: Agora da llha, 2001, p.183-190.

. O erotismo sagrado e a força do feminino em Fundador. In: DUARTE, Constância Lima; BEZERRA, Kátia da Costa; DUARTE, Eduardo de Assis. (Org.). 
Gênero e representação na literatura brasileira. Belo Horizonte: Editora Tavares Ltda, 2002, v. 2, p. 211-218.

A árvore do conhecimento, velha adivinha, e a vocação feminina de recriar o verbo em Madeira feita de cruz, de Nélida Piñon. In: BRANDÃO, Izabel e MUZART, Zahidê L. (Org.). Refazendo nós. Florianópolis: Editora Mulheres, 2003, v. 01, p.277288.

Mito e literatura: a voz das musas encarna a palavra, em Nélida Piñon e Isabel Allende. Texto apresentado no XIX Encontro Nacional da ANPOLL, em Maceió, 2004. (cedido pela autora)

O eros da fala, o mito da criação e a identidade do feminino em Vozes do deserto de Nélida Piñon. Texto apresentado no Congresso da Associação Internacional Lusitanistas, Santiago de Compostela, 2005. (cedido pela autora)

A cruz de recosmicização numa carpintaria literária: uma leitura da concepção cristã da culpa em Madeira feita de cruz, de Nélida Piñon. (cedido pela autora)

ALVES, Maria Angélica. Entre a sombra e a Luz. In: Elódia Xavier. Tudo no feminino: a mulher na narrativa brasileira contemporânea. Rio de Janeiro: Editora Francisco Alves, 1991.

ANDRADE, Maria Luiza Oliveira. Mulher e memória em Vozes do deserto, de Nélida Piñon. Texto Apresentado no Seminário Internacional Mulher e Literatura (UESC) em setembro de 2007, Ilhéus.

BOSO, Ednéa Aparecida da Silva. Os entrelaçamentos de poder, erotismo e feminismo em Vozes do deserto de Nélida Piñon. Texto apresentado no II Colóquio da PósGraduação em Letras no Programa "Literatura e Vida Social", na linha de Pesquisa 'Poéticas do Texto Literário', 2010. 
A interface literatura/cinema em Vozes do deserto de Nélida Piñon. Texto apresentado no Fazendo Gênero 9 - Diásporas, Diversidades, Deslocamentos na Universidade Federal de Santa Catarina. Florianópolis, 2010.

. Feminismo e a questão do pós-modernismo em Vozes do deserto de Nélida Piñon. Anais do XIII Seminário Nacional e IV Seminário Internacional Mulher e Literatura, Natal/RN, 2009.

- Vozes do deserto: da literatura ao cinema. Texto apresentado no III Simpósio Gêneros Híbridos da Modernidade: Literatura e Cinema, Assis, 2009.

. Feminismo e pós-modernismo em Vozes do deserto de Nélida Piñon. Texto apresentado no I Simpósio Nacional de Grupos de Pesquisa em Estudos Literários (Narrativas de Autoria Feminina), Maringá, 2009.

BUENO-RIBEIRO, Eliana. Nélida Piñon e o movimento do real (Análise e interpretação de Tempos das frutas e Sala das armas), 1979. Dissertação (Mestrado em Poética) Faculdade de Letras da Universidade Federal do Rio de Janeiro, Rio de Janeiro, 1979.

. Posfácio a Sala das armas, de Nélida Piñon. Rio de Janeiro: Edição do Autor para os Laboratórios Aché, 1990. p. 137-142.

. Nélida Piñon: moldes de fiction/ Nélida Piñon: modos de ficção. In: GODET, Rita et HOSSNE, Andréa (Orgs.). Actes du Colloque sur la literature contemporaine brésilienne (de 1970 à nos jours). Rennes, 2004 (inédito).

. Mito, paródia e rebelião: uma leitura de "Fronteira natural, de Nélida Piñon". Revista Brasileira. Rio de Janeiro, Academia Brasileira de Letras, Fase VII, JulhoAgosto-Setembro 2005, Ano XI, no 44, p. 172-188. 
CAMPELLO, Eliane Terezinha do Amaral. Nélida: jogando com destinos. In: VI Congresso de Literatura Comparada (ABRALIC), 1998, Florianópolis, SC. Anais do VI Congresso de Literatura Comparada, 1998.

O Künstlerroman de autoria feminina: a poética da artística em Atwood, Tyler, Piñon e Valenzuela. Rio Grande, RS: Editora da FURG, 2003. v. 1. 293p.

CAMPOS, Maria Consuelo Cunha. O romance da Nova República. Revista Brasileira de Língua Portuguesa e Literatura, ano VIII, número 14, 1986.

A teimosia em nomear/sonhar Brasil: À doce canção de Caetana, Matraga 6-7, vol. IV, UERJ, Janeiro-Dezembr, Rio de Janeiro, 1991, p. 72-75.

CARVALHO, Luiz Makloui. Viagem à República dos sonhos. Interview with Nélida. Leia, November, 1984, 21-23.

CARVALHO, Maria Angélica. Nélida Piñon: na força da linguagem, a Força do destino. O Globo, 04/04/1978.

CASTAÑON, Adolfo. Nélida Piñon: La casa de los destinos cruzados. América Sintaxis. México: Editorial Aldus, 2000.

CASTRO, Sílvio. Nélida Piñon. A revolução da palavra. Petrópolis: Vozes, 1976.

CASTRO-KLARÉN, Sara e MONIZ, Naomi Hoki. Interview with Nélida Piñon. Great Writer Series (videotape), Washington D.C., The Library of Congress, 1989.

CHAVES, Flávio Loureiro. Nélida Piñon: A Força do destino; O brinquedo absurdo. São Paulo: Livraria Editora Polis, 1978. 
COELHO, Nelly Novaes. O universo de Nélida Piñon. O Estado de S. Paulo, Suplemento Literário, 01/04/1973.

A literatura feminina no Brasil contemporâneo. São Paulo: Editora Siciliano, 1993.

A república dos sonhos: memória, historicidade, imaginário. A União - Correio das Artes. João Pessoa, setembro de 1985.

COSTA, Horácio. À margem de A república dos sonhos de Nélida Piñon. Luso-Brazilian Review, XXIV, Madison, University of Wisconsin.

COSTA, Maria Ignês Correa a. A criação a cada crise. Jornal de Brasília, Suplemento, 13/07/1975.

CUNHA, Fausto. O romance eletrônico: sobre o romance Guia-mapa de Gabriel Arcanjo. In: __ Situações da ficção brasileira. São Paulo: Editora Paz e Terra, 1970.

FUENTES, Carlos. Nélida Piñon dans la republique des rêves. In: . Géographie du Roman. Paris: Éditions Gallimard, p. 197-202.

Semblanza de Nélida Piñon. Discurso na recepção do Prêmio Juan Rulfo 95, Guadalajara, México, 1995.

GOMES, Carlos Magno. O papel da ópera nas trocas interculturais em Nélida Piñon. In: Anais do $X$ Congresso Internacional da ABRALIC- Lugares dos discursos. Rio de Janeiro:UERJ, 2006. 
A interculturalidade do romance de Nélida Piñon. Texto apresentado no Seminário Internacional Mulher e Literatura (UESC), em setembro de 2007, Ilhéus. Ano 3, v. $5, n^{\circ} 5$ - Jan. - Jun de 2008.

GOMES, C. M. S. Os excluídos em A doce canção de Caetana. Estudos de Literatura Brasileira Contemporânea, nº 16, UNB. Brasília, novembro/dezembro de 2001, p. 3-14.

GUIMARÃES, Denise D. Uma poética de autor: leitura de um texto de Nélida Piñon. Estudos Brasileiros, Centro de Estudos Brasileiros da Universidade Federal do Paraná, 1980.

GUIMARÃES, Júlio César Castañon. A construção de um projeto: leitura comparada de Avalovara e Fundador, 1995. Dissertação (Mestrado em Literatura Brasileira) Faculdade Cidade, 1995.

ISSA, Farida. Entrevista com Nélida Piñon. Nueva Narrativa Hispanoamericana, volume 3, número 1, 1973. Trad. Gregory Rabassa.

IVO, Ledo. A voz de longe e de perto. Discurso de resposta na recepção de Nélida Piñon na Academia Brasileira de Letras, 03 de maio de 1990.

JOSEF, Bella. Review of Nélida Piñon - A república dos sonhos (Resenha). Colóquio Letras, número 86, julho de 1985.

JUNKES, Lauro. Nélida Piñon: u ma escritora conta outra história do Brasil - é a versão dos netos. Revista Letras (April), 1985.

LAPOUGE-PETTORELLI, Maryvonne. Écrire dans la Langue Portugaise du Brésil, c'est révéler lê Brésil tel qu'il est. Quinzaine Littéraire-Écrivains du Brésil, número 468,16-30, abril de 1987. 
LARA, Cecília de. O indevassável casulo: uma leitura de $A$ república dos sonhos. Revista do Instituto de Estudos Brasileiros, nº 27, Universidade de São Paulo, São Paulo, 1987, p. 27-36.

LEAL, César. Dom Álvaro e Nélida Piñon. In: . Entre o leão e o tigre: breves ensaios sobre teoria e crítica do poema. Recife: Editora Massangana, 1987.

LEPECKI, Maria Lúcia. Nélida Piñon: Tebas do meu coração. Colóquio/Letras, Lisboa, 33, setembro, 1976, pp. 97-99.

LISPECTOR, Clarice. Nélida Piñon: de corpo inteiro. Rio de Janeiro: Artenova, 1975.

LOBO, Suely Maria de Paula e Silva. No corpo da escrita o jogo e as máscaras: um estudo da construção do texto literário em Fay Weldon, Grace Paley e Nélida Piñon. Belo Horizonte: FALE/UFMG, 1996, p. 285.

MARINHO, Beatriz. Nélida Piñon: ilusão, matéria-prima fundamental. O Estado de $S$. Paulo, Cultura, 02/03/1991, p. 2.

MARRECO, M. Inês. A errância infatigável da palavra. 1997, 124f. Dissertação (Mestrado em Letras) - Pontifícia Universidade Católica - PUC/MG. Belo Horizonte, 1997.

MCNAB, Gregory. Abordando a história em $A$ república dos sonhos. Brasil/Brazil, 1, 1988.

MEDINA, Cremilda Araújo. Embarque no sonho desta república. A posse da terra escritor brasileiro hoje. São Paulo, Imprensa Nacional/Casa da Moeda, Secr. Cultura do Estado de São Paulo, 1985. 
MEYERFELD, Regina Antunes; CURY, Maria Zilda Ferreira. Mémoires éxilées: trajectoire d'um immigrant dans lê roman 'A república dos sonhos' de Nélida Piñon. In: MONTANDON, Alain; PITAUD, Philippe. (Org.). Vieillir em exil. 1. ed. Clermont-Ferrand: Presses Universitaires Blaise-Pascal, 2006, v. 1, p. 61-67.

MINDLIN, Dulce Maria Viana. Pelos lábios da sibilia: A força do destino. In: Ficção e mito: a procura de um saber. Goiânia: CEGRAF, 1992.

MONIZ, Naomi Hoki. Ética, estética e a condição feminina. Revista Iberoamericana, volume 50, número 126, janeiro-março de 1984.

As viagens de Nélida, a escritora. Campinas, São Paulo: Editora da UNICAMP, 1993. Prêmio Melhor Livro de Ensaios do Ano pela APCA (Associação Paulista de Críticos de Arte).

Nélida Piñon: a questão da história em sua obra. In: SHARPE, Peggy (Org.). Entre resistir e identificar-se: para uma teoria da prática da narrativa brasileira de autoria feminina. Florianópolis: Editora Mulheres: Goiânia: CEGRAF, 1997.

NASCIMENTO, Dalma Portugal. A incandescente transgressão em o Calor das coisas. In: . Perspectivas: ensaios de teoria e crítica. Universidade Federal do Rio de Janeiro, Faculdade de Letras, Departamento de Ciência da Literatura, 1984.

A Galiza reiluminada por Stella Leonardos e Nélida Piñon. In: Cadernos de Letras da UFF, Niterói, Instituto de Letras - UFF, no 05, 1992, p. 60-74.

NASCIMENTO, Lílian Soier. A república dos sonhos, de Nélida Piñon: imigração e memória. 2005. Dissertação (Mestrado em Estudos Literários) - Universidade Federal de Minas Gerais, Belo Horizonte, 2005.

NEPOMUCENO, Eric. A paixão medida. Leia Livros, janeiro de 1988. 
NUNES, Glória Elena Pereira. O ficcional, a identidade e a transgressão na narrativa de Nélida Piñon.1997. 100f. Dissertação (Mestrado em Letras). Rio de Janeiro. Pontifícia Universidade Católica do Rio de Janeiro, Rio de Janeiro, 1997.

NUNES, Maria Luísa. Nélida Piñon. A força do destino (Resenha). Revista Iberoamericana, volume 45, números 108-109, janeiro-dezembro de 1979.

ORNELLAS, José. El mundo simbólico y filosófico de Madeira Feita Cruz de Nélida Piñon. Nueva Narrativa Hispanoamericana, volume 3, número 1, janeiro de 1973.

PARKER, John M. Life in Limbo (Resenha). Times Literary Suplement, 08/06/1976, p. 99.

PAULINO, Maria das Graças Rodrigues. Fundador: a subversão do mito. In: WALTY, Ivete Camargo e RAMOS, Maria Luiza (Orgs.). Ensaios de Semiótica 2. Cadernos de Lingüística e Teoria da Literatura. Faculdade de Letras, Universidade Federal de Minas Gerais, 1979.

POLK, James. Living is an Act of Fantasy (Resenha). The New York Times, 30/07/1989.

PÓlvoRA, Hélio. Nélida Piñon. Machado, Graciliano, Drummond e Outros. Rio de Janeiro: Francisco Alves, 1975.

PORTO, Maria Bernadette. La représentation de l'actrice chez Nélida Piñon, Lygia Fagundes Telles et Anne Hébert. In: AA. VV. Confluences Littéraires Brésil-Quebec: les bases d'une comparaison. Montréal: Les Éditions Balzac, 1991. (Collection L'Univers du Discours)

PORTO, M. Bernadete Velloso. Memórias e aprendizaxes: oralidade e escritura em $A$ república dos sonhos de Nélida Piñon. In: MALEVAL, M. do A. Tavares (Org.). Actas 
das II Xornadas UFF de Cultura Galega, Niterói, Núcleo de Estudos GalegosUFF/Santiago, Xunta de Galícia, 1995, pp. 177-182.

PRIAMI, Elda. Um novo espaço para a mulher na literatura feminina. $O$ Globo, 12/07/1980.

QUINLAN, Susan Canty. History Revisited: Nélida Piñon's A república dos sonhos. Literatura de vanguarda luso-brasileira. Hispanic Studies Series, 4. (1989), 164-169.

A história revisitada: A república dos sonhos de Nélida Piñon. Revista Iberoamericana- Brasil, Brasis, ou: a hora e a vez das minorias étnicas. vol. LXXXVI, no 230, Enero-Marzo 2010, p. 133-151.

RÉGIS, Sônia. Sarça ardente. Posfácio à $4^{a}$ edição de $A$ casa da paixão. Rio de Janeiro: Nova Fronteira, 1982.

O mito do signo icônico na obra de Nélida Piñon. Cadernos PUC-SP. 'Semiótica da Literatura' 28, 1987, p. 181-18.

RIBEIRO, Eliana Bueno. Nélida Piñon e o movimento do real. Dissertação (Mestrado em Poética). 1978. - Faculdade de Letras da Universidade Federal do Rio de Janeiro (UFRJ), Rio de Janeiro, 1978.

ROCHA, Diva Vasconcellos da. Das rias ó Rio: Guia-Mapa de Nélida Piñon. In: MALEVAL, M. Do A. Tavares (Coord.), Actas das II Xornadas UFF de Cultura Galega, Niterói, Núcleo de Estudos Galegos-UFF/Santiago, Xunta da Galiza, 1995, p. 163-169.

ROCHA, Luis Carlos Moreira. Gênero, raça e historicidade na escrita feminina dos anos 80: análise de $A$ república dos sonhos, de Nélida Piñon. In: CUNHA, Helena Parente (Org.). Desafiando o cânone: aspectos da literatura de autoria feminina na prosa e na poesia (anos 70/80). Rio de Janeiro: Tempo Brasileiro, 1999. 
ROUCHOU, Joelle. Esforço de mulher pela cultura. Jornal do Brasil, 08/06/1980.

RUTA, Suzanne. A Village of Quixotes (Resenha da Tradução Inglesa por Helen Lane, Caetana's Sweet Song). The New York Times Book Review, Nova York, A. Knoph, 22/05/1992, p. 7.

RYAN, Alan. Chronicle of a Brazilian Family (Resenha). The Washington Post, 30/07/1979.

SANTOS, Wendel. Os três reais da ficção: história, mito e metafísica em Nélida Piñon. In: . Os três reais da ficção: o conto brasileiro hoje. Petrópolis /RJ: Editora Vozes, 1978.

SCHILLER, Beatriz. A censura (no Brasil inclusive) é tema de debate em Nova York. Jornal do Brasil, 11/02/1980.

SCHMIDT, Rita Terezinha. Um jogo de máscaras: duplicidade em Nélida Piñon e Mary Mc Carthy. In: GAZOLLA, Ana L. Almeida (Org.), A mulher na literatura. vol. 1. Cidade: Editora.1990, pp. 207-222.

SECCO, Carmen Lúcia Tindó. As rugas do tempo nas dobras do literário. 1992. Tese. (Doutorado em Literatura Brasileira) - Faculdade de Letras da Universidade Federal do Rio de Janeiro/UFRJ, Rio de Janeiro, 1992.

Nélida Piñon: a viagem pela língua e a alquimia rebelde do verbo criador. In: Actas do IV Congresso Internacional da Língua Galego-Portuguesa na Galiza, Vigo, 1996, pp. 345-350.

SERPA, Ângela. A (re)criação simbólica. 1993. Dissertação (Mestrado) - Departamento de Letras e Linguística, Universidade Federal de Pernambuco, Recife,1993. 
SHARPE, Peggy. Entre resistir e identificar-se: para uma teoria da prática da narrativa brasileira de autoria feminina. Florianópolis: Editora Mulheres; Goiânia: Editora da UFG, 1997.

SHREVE, Jack. The Republic of Dreams (Resenha). Library Journal, 15/05/1989.

SIMÕES, Cleide. Nélida Piñon. Suplemento Literário de Minas Gerais, XXII, número $1.129,02 / 09 / 1989$.

SOARES, Leonardo Francisco. Rotas abissais: mimese e representação em $A$ força do destino, de Nélida Piñon e E la nave va, de Frederico Fellini. 2000. 140 f. Dissertação (Mestrado em Letras) - FALE/UFMG. Belo Horizonte, 2000..

SOBRAL, Patrícia Isabel Santos. Belonging and Displacement: Cultural Interspaces in Brazilian Literature. Dissertation Requirements for the Degree of Doctor of Philosophy, University of Illinois, 1997.

- Entre fronteiras: a condição do migrante n'A República dos Sonhos. Portuguese Literary \& Cultural Studies, 1 Fall 1998, p. 67-87.

SPIELMANN, Ellen. Ein Roman als ort literarischer selbstreflexion - Nélida Piñon: $A$ força do destino. Tese sob a orientação do Prof ${ }^{\circ}$ Victor Farias, Lateinamerika - Institut der Freien Universität Berlin, 02 junho 1984.

STEEN, Edla Van. Escrever e viver. Brasília: L\&PM, P.A.INL, 1982. V. II.

STEINBERG, Sybil. The Republic of Dreams (Resenha). Publisher's Weekly, volume 235, número 17, 28/04/1989.

TEIXEIRA, Níncia Borges. Entre o ser e o estar: a mulher no universo literário de Nélida Piñon. Revista Mulheres e Literatura, Ano 10, vol. 11, 2006. Rio de Janeiro: UFRJ. 
TEIXEIRA, Vera Regina. Texto, contexto e pretexto na obra de Nélida Piñon. Letras de Hoje, v. 30, Porto Alegre, 1995. p. 109-117.

TELLES, Norma. Círculos da moral: A doce canção de Caetana (Resenha). ISTO É, 30/12/1987.

TORRES, Maximiliano. As faces de Medeia na narrativa de Nélida Piñon: a dinâmica do amor e da loucura em O revólver da paixão. CD-Rom do XI Seminário Nacional Mulher e Literatura \& II Seminário Internacional Mulher e Literatura - GT ANPOLL "Entre o estético e o político: a questão da mulher na literatura; Rio de Janeiro: Agosto de 2005.

. Vozes (des)veladas, veludosas vozes: a escuta aprimorada de Nélida Piñon. NIELM em Foco: Boletim informativo do Núcleo Interdisciplinar de Estudos da Mulher na Literatura. Ano IV - no 4; Faculdade de Letras/ UFRJ; Rio de Janeiro: setembro de 2005. p. 02.

A força do destino: a ópera literária de Nélida Piñon. CD-Rom do X Congresso Internacional da ABRALIC "Lugares dos discursos"; Rio de Janeiro: 2006.

As incursões do erotismo na escrita de Nélida Piñon: uma leitura d'A casa da paixão. Texto publicado na revista virtual do Programa de Pós-Graduação em Ciência da Literatura da Faculdade de Letras da UFRJ.

VARGAS LLOSA, Mario. Palabras de Vargas Llosa em la Presentación de um Libro de Nélida Piñon. Revista de Cultura Brasileña, Madrid, número 48, janeiro de 1979.

VIEIRA, Nelson H. Saudade, 'morriña' e analepse: o elemento galego na ficção memorialista de Nélida Piñon". In: CARREÑO, Antonio (Coord. e de.), Actas do Segundo Congreso de Estúdios Galegos. Homenaxe a José Amor y Vasquez, Vigo: Galáxia, 1991, pp. 327-336. 
VILLARINO PRADO, M. Carmen. O quotidiano no feminino: alguns contos de Nélida Piñon. In: SARAIVA, Arnaldo (Ed.). A literatura brasileira em questão. Porto (Portugal): Universidade do Porto, 2000.

- 'Elas por elas'. Clarice Lispector e Nélida Piñon na prosa brasileira actual de autoria feminina. In: CARRASCO, J.M. et alii (Ed.). Actas del Congreso Internacional de Historia y Cultura em la frontera. Cáceres (Espanha): Universidad de Extremadura Junta de Extremadura, 2000.

A Literatura brasileira de autoria feminina nos últimos anos: a escritora à procura de uma identidade. In: AES, Actas del IX Congreso Internacional de la Asociación Española de Semiótica, v. CD-Rom. Valencia (Espanha): Asociación Española de Semiótica, 2000.

A literatura brasileira: uma existência entre bastidores. (Década de 1970)". In: RODRÍGUEZ, J.L. (Ed.). Estudos dedicados a Ricardo Carvalho Calero, v. II Santiago de Compostela: Universidade de Santiago de Compostela-Parlamento de Galícia, 2000. p. 825-850.

. A Galiza sonhada por alguns escritores brasileiros. Nova Renascença, v. XIX, n. 72/73, Porto, 2001. p. 329-341.

A Galiza: um material de repertório priorizado na obra de Nélida Piñon. Cadernos Vianenses, v. XXX, Viana do Castelo (Portugal), 2001, p. 93-120.

Quarenta anos de uma estrela. A entrada de Nélida Piñon no campo literário brasileiro com Guia-mapa de Gabriel Arcanjo. Veredas. Revista da Associação Internacional de Lusitanistas, n. 4, Coimbra (Portugal), 2001. p. 195-231. 
A trajetória de Nélida Piñon entre 1961 e 1980. Brasil/Brazil. Revista de Literatura Brasileira, n. 27, Brown University (EUA)/PUCRS-Porto Alegre (Brasil), 2002. p. 42-72.

Comunidades emigrantes no Brasil: imprensa, publicações literárias e língua(s) que as veiculam. O caso dos galegos". In: LORENZO, R. (Ed.), Homenaxe a Fernando R. Tato Plaza, Cidade e editora, 2000.

SANTIAGO DE COMPOSTELA (ESPANHA): Servicio de Publicacións da Universidade de Santiago de Compostela, 2002. p. 383-395.

VILLARINO PRADO, M. Carmen. Posición y trajectoria de uma escritora brasileña. In: Homenaje a Nélida Piñon. XVII Premio Menéndez Pelayo. Madrid-Santander: Universidad Internacional Menéndez Pelayo, 2003. p. 73-141.

- Encontros de escritores brasileiros nos finais da década de 1970: um mecanismo de institucionalização e de mercado. Estudos de Literatura Brasileira, n. 23 (Jan./Jun), Brasília: Universidade de Brasília, 2004. p. 151-168.

Entre a via-crucis e o prazer: representação da mulher transgressora na prosa brasileira recente de autoria feminina. In: TOSCANO, A. e GODSLAND, S. (Edrs.), Mulheres más: percepção e representações da mulher transgressora no mundo lusohispânico. Porto (Portugal): Edições Universidade Fernando Pessoa, 2004. p. 283-298.

A conquista de autoridade intelectual em meados dos anos 70 no Brasil. Polêmicas, debates e boom editorial. In: Actas do VIII Congresso da Associação Internacional Lusitanistas, Santiago de Compostela, Universidade de Santiago de Compostela-AIL. 
Usos repertoriales del yo em la prosa brasileña de inícios de los 90: el caso de Nélida Piñon. Literatura y Revolución, º sem. 2005, Casa de lãs Américas, La Habana (Cuba), 2005. p. 34-47.

. Outras vozes de Nélida Piñon. A festa da palabra silenciada, № 20. Santiago de Compostela (Espanha), 2005. p. 23-30.

. Dinâmicas y líneas de fuerza em la literatura brasileña del siglo XX. Revista de Cultura Brasieña. V. 3. Embajada de Brasil em Madrid, 2005. p. 46-78.

- Revisitando o mito de Sherezade. Tempos Novos, no 92. Santiago de Compostela (Espanha), 2005 (jan.). p. inicial 74.

WYLER, Vivian. Ferro em Brasa. Jornal do Brasil, 21/05/1980.

ZAGURY, Eliane. O novo telurismo de Nélida Piñon: a palavra e os ecos. Petrópolis, Vozes, 1971.

ZIRPOLI, Ilzia Maria. Vidas re-compostas: aventureiras, peregrinas, viajantes: (contos de Nélida Piñon). Recife: Programa de Pós-Graduação em Letras/UFPE, 2005. 91 p. (Teses) ISBN 8598968099 (broch.)

ZOLIN, Lucia Osana. Lucidez e ironia tecidas pela linguagem: uma teoria do feminino em 'I love my husband', de Nélida Piñon. In: XI Seminário do CELLIP- Centro de Estudos Lingüísticos e Literários do Paraná, 1997, Cascavel. XI Seminário do CELLIP Centro de Estudos Lingüísticos e Literários do Paraá, 1997. v. 1.

A mulher na literatura: um passeio pela obra de Nélida Piñon. In: . Brasil: 500 anos de descobertas literárias, 2004, Brasília. Brasil 500 anos. Brasília: Universidade de Brasília, 2000. 
A república dos sonhos, de Nélida Piñon: a trajetória da emancipação feminina. 2001. Tese. (Doutorado em Letras) - Universidade Estadual Paulista Júlio de Mesquita Filho - UNESP, São José do Rio Preto, SP, 2001.

A representação da mulher em A república dos sonhos, de Nélida Piñon: Eulália, o protótipo da resistência passiva. In: Anais do IX Seminário Nacional "Mulher e Literatura", Belo Horizonte. Mediações - VIII Congresso Internacional Abralic - Anais. Santo Amaro, SP: NovoDisc Brasil Indústria Fonográfica Ltda, 2002.

A representação da mulher em $A$ república dos sonhos, de Nélida Piñon: Eulália, o protótipo da resistência passiva. In: DUARTE, Constância Lima; DUARTE, Eduardo de Assis; BEZERRA, Kátia da Costa. (Orgs.). Gênero e representação na literatura brasileira. 1 ed. Belo Horizonte: Gráfica Editora Tavares, 2002. v. 2, p. 203210.

A reescritura de Missa do Galo através de um olhar feminino. Acta Scientiarum, Maringá, 23(1): 103-108, 2001. ISSN 1415-6814.

A imagem da mulher no romance contemporâneo: uma leitura de $A$ república dos sonhos, de Nélida Piñon. In: 14 Congresso de Leitura no Brasil - COLE, 2003, Campinas. 14ํㅡㄹ Congresso de Leitura no Brasil/ II Congresso da história do livro e da leitura no Brasil. Campinas: ABL, 2003. p. 53-53.

Desconstruindo a opressão: a imagem feminina em $A$ república dos sonhos, de Nélida Piñon. Maringá: Eduem - Editora da Universidade de Maringá, Paraná, 2003.

Esperança: a trajetória de uma guerreira. In: Anais do X Seminário Nacional I Internacional "Mulher e Literatura", João Pessoa (PB): Universidade Federal da Pariba, agosto 2003. 
ZOLIN, Lúcia Ozana; VILLIBOR, Roberta Fresneda. Literatura de autoria feminina e reescrita: a Scherezade de Nélida Piñon. In: 15ำ congresso de leitura no Brasil. UNICAMP: ABL; Faculdade de Educação, 2005. p. 61-61.

ZOLIN, Lúcia Osana. A personagem feminina na literatura brasileira escrita por mulheres: de objeto a sujeito. In: Anais do XI Seminário Nacional, II Internacional "Mulher e Literatura", Rio de Janeiro: UERJ, agosto 2005.

\section{Artigos Publicados na Imprensa (Revistas Literárias)}

ARAGÃO, Maria Lúcia. A paródia em A força do destino. Tempo Brasileiro, no 62, Rio de Janeiro, julho-setembro 1980.

BONFIM, Maria C. de Mesquita. Depoimento da Acadêmica Nélida Piñon. Gravado na Sala dos Fundadores do Petit Trianon - Academia Brasileira de Letras em 08 de outubro de 1998. Transcrição: Tânia Lúcia Oliveira Barreto. Revisão: M. C. de M e Nélida Piñon. Fonte: http://virtualbooks.terra.com/osmelhoresautores/biografias/NelidaPinon.htm

CAMPOS, Maria Consuelo Cunha.. Ave do paraíso. Ficção, Rio de Janeiro: Editora Gradus, agosto 1977.

CARVALHO, L.M. Viagem à República dos sonhos. Leia, no 73, v. 7, São Paulo, 1984, p. 22-3, novembro.

CARVALHO, M. A. Nélida Piñon: na força da linguagem, a força do destino. O Globo, Rio de Janeiro, 04 de abril 1978. n.p.

CASTRO, Silvio. Arcanjo Gabriel. Jornal do Commercio, Rio de Janeiro, 20 março, 1961. 
CASTRO, Silvio. Nélida Piñon, a primeira. Jornal das Letras, Lisboa, 29 janeiro 1997.

COELHO, Nelly Novaes. O universo de Nélida Piñon. O Estado de S. Paulo, São Paulo, 1 de abril 1973. Suplemento Literário, p. 2.

COSTA, Horácio. A margem de A República dos sonhos, de Nélida Piñon. LusoBrazilian Review, XXIV, 1, Summer, 1987: 1-15.

COURI, Norma. Nélida Piñon: a mulher ainda não conseguiu criar a sua linguagem. Escrita 4, Ano 1, 1986, p. 4-7.

CRESPO, Angel e BEDATE, Pilar Gómez. Nélida Piñon, de Guia Mapa a Tempo das Frutas. Revista de Cultura Brasileña, n. 24, Suplemento Especial, Madri, Embaixada do Brasil, março 1968, p. 1-56.

CUADRA, Ivonne. Sexualidade, erotismo y lenguaje en A casa de paixão de Nélida Piñon. Argos, Revista de Literatura, no 20, noviembre - enero de 2002. Guadalajara: Departamento de Letras, Universidad de Guadalajara.

DUARTE, José Afrânio Moreira. Duas grandes ficcionistas. In: Opinião Literária. São Paulo: Editora do Escritor, 1981.

HIDALGO, Luciana. Clarice, Nélida e Lygia revisitadas com carinho. O Globo, Rio de Janeiro, 15 agosto 1998.

HINCHBERGER, Bill. A Storyteller of Modern Myth. Américas. 49.1 (Jan-Feb. 1997): $40-$ 45. (texto integral na seção "Resenhas").

HORTA, Maria Teresa. Xerazade a dona das palavras que pronuncia. Diário de Notícias, Portugal, Quarta-feira, Edição Papel, 15 de dezembro de 2004. 
MAURA, Antonio. Nélida Piñon (entrevista em espanhol). El Urogallo 110/111, JulhoAgosto, Madri, 1995, pp. 68-78.

McNAB, Gregory. Abordando a história em $A$ república dos sonhos. Brasil/Brazil. Revista de Literatura brasileira, № 1, Ano 1, 1988, pp. 41-53.

MEGIAS, José Manuel Lúcia. Nélida Piñon. Diário de Alcalá (Espanha), 20 junho 2006.

MIGUEL, Mariana Correia Mourente. O caminho da não-violência em Vozes do deserto. Revista Ártemis, v. 2, p. 3, 2005.

MONIZ, Naomi Hoki. A casa da paixão: ética, estética e a condição feminina. Revista Iberoamericana 126 (Jan.-Mar. 1984): 129-140.

MORAES NETO, G. Nélida , canta a academia. Jornal do Brasil, Rio de Janeiro, 05 dez. 1987. Caderno Idéias.

NEVES, Tânia. Nélida Piñon: viagem ao centro da cebola. O Globo, 17 de março, 1990, p. 3.

NORRIS, Nélida. Conversando com Nélida Piñon. Alba de América. 13. 24-25 (July 1995): 519-528.

PARADA, Javier Garcia. La fantástica forma de la escritura. Revista eletrônica La Palabra.

PEREIRA JUNIOR, Luiz C. A Paixão Feminina pela Palavra. Revista Língua Portuguesa. Entrevista. Fonte: http://revistalingua.uol.com.br/textos.asp?codigo=11112. 
PIMENTEL, S. Nélida Piñon consagra boa fase com obras relançadas. Folha de $S$. Paulo, São Paulo, 26 set. 1998. Folha Ilustrada, p. 12.

PONTIERO, Giovanni. Notes on the fiction of Nélida Piñon. Review 76 19, Inverno, 1976, pp. 67-71.

PROENÇA FILHO, Domício. A inquieta ficção de uma mulher cidadã e escritora. Folha de S. Paulo, São Paulo, 26 set. 1998. Folha llustrada, p. 4.

REGIS, Sônia. A república dos sonhos: entre a imaginação e a realidade. $O$ Estado de S. Paulo. Suplemento Literário, p. 8. São Paulo, 6 de janeiro 1985.

RENOLDI-TOCALINO, Magda M. Romances de formação de busca de Nélida Piñon e Marta Traba. Revista Interamericana de Bibliografia (RIB), 1998, no 2,p. 317-328.

RIERA, Carmen. Entrevista com Nélida Piñon: la vida es la literatura. Quimera. n.d., 5455: 44-49.

RÜF, Isabelle. Lês irisations du Brésil, par la voix de sés écrivains - Nélida Piñon, l'aventurière de l'âme. Lê temps, Genebra, 4 de maio 2002. Samedi Culturel.

SCHILD, Suzana. Nélida Piñon: A república dos sonhos. Revista IBM, v. 19, São Paulo, 1984. p. $11-17$

SILVA, D. Nélida Piñon: uma escritora conta outra história do Brasil - é a versão dos netos. Letras Hoje, v. 17, Porto Alegre, 1984. p. 119-121.

TOSAR, Luis González. Nélida Piñon ou a paixón de contar (entrevista). Grial: Revista Galega de Cultura 105, tomo XXVIII, Janeiro-Março, 1990, pp. 85-95. 


\section{Artigos Eletrônicos}

A edição de janeiro- abril 2005 da Revista WLT - World Literature Today vol. 79, № 1, dedica seção especial a Nélida Piñon. http://www.ou.edu/worldlit/onlinemagazine/2005spring/

"As palavras erotizam a realidade". Entrevista realizada em 18 de outubro de 2005. Fonte: $\quad$ http://diversao.uol.com.br/ultnot/2005/10/18/ult1817u3948.jhtm. Pesquisa realizada em 29 de dezembro de 2008.

A paixão feminina pela palavra. Revista Língua Portuguesa. Entrevista concedida a Luiz C. P. Junior. Fonte: http://revistalingua.uol.com.br/textos.asp?codigo=11112

"As mil e uma Noites de Nélida". Entrevista concedida a Luis Eduardo em 11/05/2004. Fonte: http://www.digestivocultural.com/colunistas/coluna.asp?codigo=1354

Interpretações da memória. Fonte: Folha de S. Paulo, 8 de Agosto, 1999.

Nélida Piñon, o navio e a lagoa. Fonte: Folha de S. Paulo Ilustrada, 21 de Dezembro, 1997.

Cineasta Lafaietense realiza longa-metragem. Fonte: www.estadoatual.com.br

Nélida Piñon protagoniza o documental "Scherezade en Galícia". Fonte: http://www.xornal.com/article.php3?sid=20061117150149Xornal.com - el primer diário electronico de Galícia, Viernes, 17 de noviembre de 2006.

O ano de Ouro de Nélida Piñon. Entrevista. Quarta-feira, 04 de janeiro de 2006. Fonte: http://www.digestivocultural.com/colunistas/coluna.asp?codigo=1800. 
Opinião Acadêmica. Fonte: http://www.ritotal.com.br/coojornal/academicosleodegario003.htm. Revista Rio Total - Coojornal, Número 263.ISSN 1676-9023, 15 de junho de 2002.

A Força do Arcaico. Fonte: www.continentemulticultural.com.br. Revista Continente Multicultural № 58, Outubro de 2005.

Nélida Piñon fala de literatura em congresso na Espanha. Folha Online - 05 de abril, $2006-16 h 44$.

A TVG prepara un documental de Nélida Piñon. Fonte: www.galicia-hoxe.com

Depoimento da Acadêmica Nélida Piñon. Gravado na Sala dos Fundadores do Petit Trianon - Academia Brasileira de Letras em 08 de outubro de 1998 por: Maria Cláudia de Mesquita e Bonfim. Transcrição: Tânia Lúcia Oliveira Barreto. Revisão: M.C. de M.e Nélida Piñon. Fonte:http://virtualbooks.terra.com/osmelhoresautores/biografias/Nelida Pinon.htm

Nélida Piñon - Jornalista, Romancista, Escritora e Professora Imortal da Academia Brasileira de Letras. Perfil. Entrevista concedida ao Portal NetBabillons. Fonte: http://www.netbabillons.com.br/gente/NelidaPinon/Nelida01.htm

Nélida Piñon quer abertura maior nos 100 anos da AB. Folha de S. Paulo/ Brasil -21 de julho de 1997 por Fernanda da Escóssia a Sucursal do Rio. Fonte: http://www.nelidapinon.com.br/panorama/inte/pan entervistas 100anosABL.php

Entrevista A vencedora do Prêmio Jabuti 2005 de melhor romance fala da companhia (da escrita e dos elementos que compõem a ficção de qualidade). Fonte: http://www.nelidapinon.com.br/panorama/inte/pan entrevistas jabuti.php

La brasileña Nélida Piñon se alza con el Príncipe de Astúrias de las Letras 2005. 17/Jun/05. 
Don Quijote y Sancho, dos poetas de lo posible, considera Piñon. Fuente: http://www.jornada.unam.mx/2006/05/29/a04n1cul.php de 29 de Mayo de 2006.

Nélida Piñon, la pasión por la palabra. Fuente: http://www.hoy.es/pg06045/prensa/noticias/Sociedad/200604/05/HOY-SOC-194.html de 06 de abril del 2006.

El oro del relato. Fuente: www.lavozdegalicia.es de 16 de abril del 2005.

Nélida Piñon hace um canto a Brasil, al cosmopolitismo y a la cultura del mestizaje. Fuente: EL PAíS de 11 de Julio del 2003.

O Eros da fala, o mito da criação e a identidade do feminino em Vozes do deserto de Nélida Piñon. Fonte: http://www.nelidapinon.com.br/panorama/inte/pan resenas erosdafala.php

La fantástica forma de la escritura (Nélida Piñon en las Atenas Veracruzana). Fuente: http://esp.mexico.com/lapalabra, 24 de Mayo del 2006.

Nélida Piñon, José Manuel Lucía Megías. Diário de Alcalá, Alcalá de Henares, Espanha, 20 de Junio del 2006.

Vozes do Deserto, de Nélida Piñon, é lançado em Nova York. Site consultado 23 de set. de 2009. http://www.comunidadenews.com/cultura/vozes-do-deserto-de-nelida-pinon-elancado-em-nova-iorque-

Bibliografia resumida de Nélida Piñon.

Fonte: http://www.academia.org.br/abl/cgi/cgilua.exe/sys/start.htm?infoid=460\&sid=290

Vozes do deserto: Scherezade, Guerrilheira da imaginação . Entrevista. Site consultado em 23 de set, 2009. Fonte:http://www.circuloleitores.pt/cl/artigofree.asp?cod artigo=107974 